\title{
Lighting Energy Efficiency Opportunities at Cheyenne Mountain Air Station
}

by J.C. Molburg, A.J. Rozo, J.K. Sarles, R.A. Haffenden, P.R. Thimmapuram, and J.D. Cavallo

Environmental Assessment Division and Decision and Information Sciences Division, Argonne National Laboratory, 9700 South Cass Avenue, Argonne, Illinois 60439

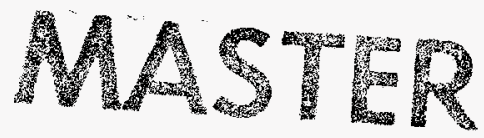

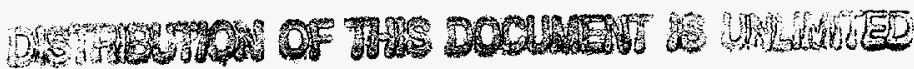

June 1996

Work sponsored by United States Air Force,

71st Civil Engineering Squadron, Environmental Section 
बतs

This report is printed on recycled paper. 


\section{Lighting Energy Efficiency Opportunities at Cheyenne Mountain Air Station}

\section{SUMMARY}

The physical and operational attributes of the Cheyenne Mountain Air Station (CMAS) provide a unique opportunity for evaluating lighting-related energy conservation measures. CMAS is an intensive user of electricity for lighting because of its size, lack of daylight, and 24-hour operating schedule. Argonne National Laboratory recently conducted a lighting energy conservation evaluation at CMAS. The evaluation included inspection and characterization of existing lighting systems, analysis of energy-efficient retrofit options, and investigation of the environmental effects that these lighting system retrofits could have when they are ready to be disposed of as waste. Argonne devised three retrofit options for the existing lighting systems at various buildings: (1) minimal retrofit - limited fixture replacement; (2) moderate retrofit - more extensive fixture replacement and limited application of motion detectors; and (3) advanced retrofit - fixture replacement, reduction in the number of lamps, expansion of task lighting, and more extensive application of motion detectors. Argonne used data on electricity consumption to analyze the economic and energy effects of these three retrofit options. It performed a cost analysis for each retrofit option in terms of payback.

The analysis showed that lighting retrofits result in savings because they reduce electricity consumption, cooling load, and maintenance costs. The payback period for all retrofit options was found to be less than 2 years, with the payback period decreasing for more aggressive retrofits. These short payback periods derived largely from the intensive (24-hours-per-day) use of electric lighting at the facility. Maintenance savings accounted for more than half of the annual energy-related savings under the minimal and moderate retrofit options and slightly less than half of these savings under the advanced retrofit option. Even if maintenance savings were excluded, the payback periods would still be impressive: about 4.4 years for the minimal retrofit option and 2 years for the advanced option. The local and regional environmental impacts of the three retrofit options were minimal. 
This report can be accessed directly on the Internet with Acrobat by setting the URL to: http://www.dis.anl.gov/Bldgs/eber/cmas_doc.html

Other information on energy efficiency is accessible at:

http://www.dis.anl.gov/ee/ee.html 


\section{DISCLAMMER}

Portions of this document may be illegible in electronic image products. Images are produced from the best available original document. 


\section{CONTENTS}

PROJECT OVERVIEW AND BACKGROUND $\ldots \ldots \ldots \ldots \ldots \ldots \ldots \ldots \ldots \ldots$

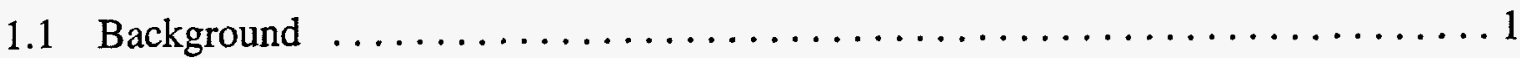

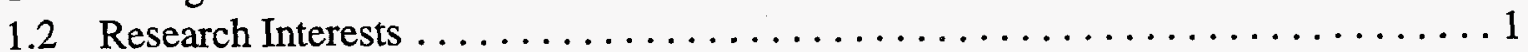

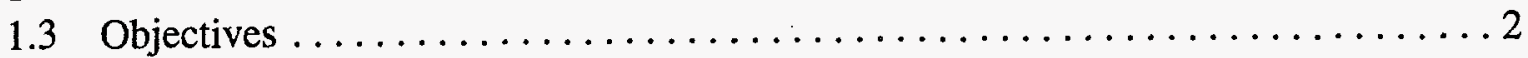

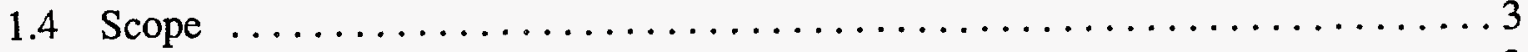

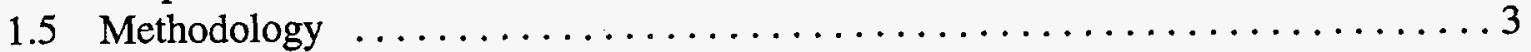

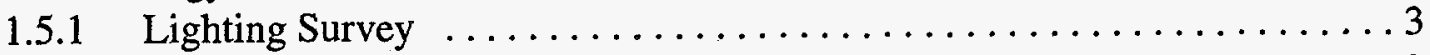

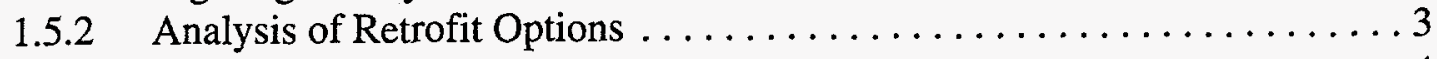

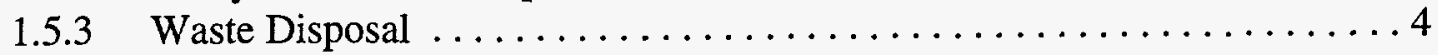

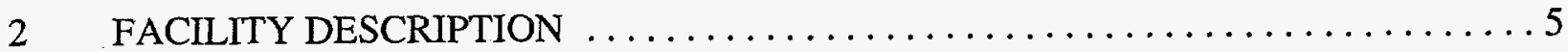

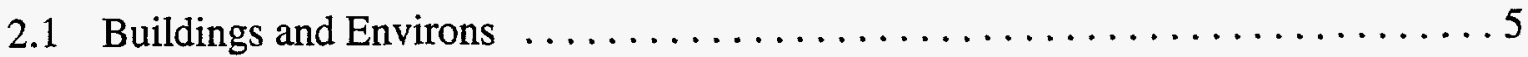

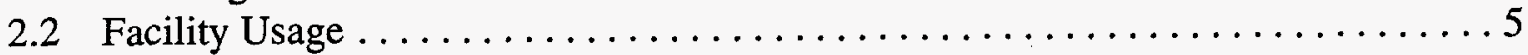

3 LIGHTING SURVEY $\ldots \ldots \ldots \ldots \ldots \ldots \ldots \ldots \ldots \ldots \ldots \ldots \ldots \ldots \ldots \ldots \ldots$

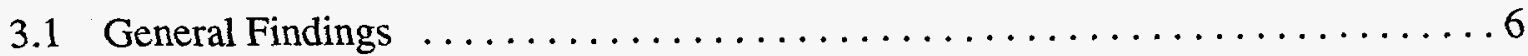

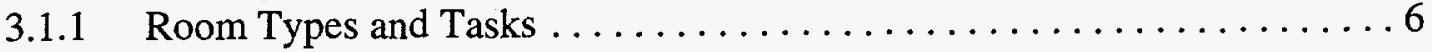

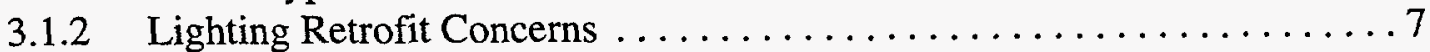

3.1.3 Current Lighting Systems and Levels $\ldots \ldots \ldots \ldots \ldots \ldots \ldots \ldots \ldots$

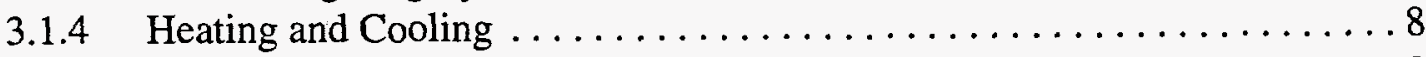

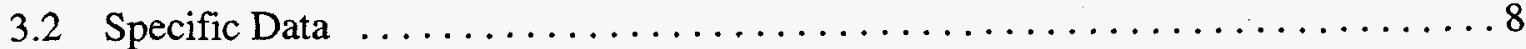

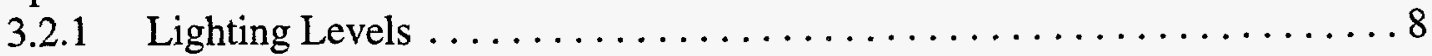

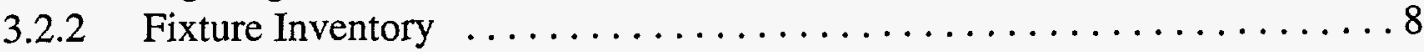

4 GENERAL RETROFIT OPTIONS $\ldots \ldots \ldots \ldots \ldots \ldots \ldots \ldots \ldots \ldots \ldots \ldots \ldots$

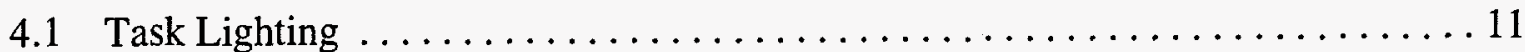

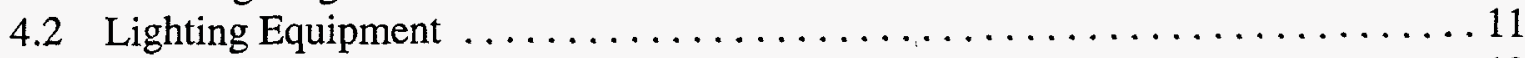

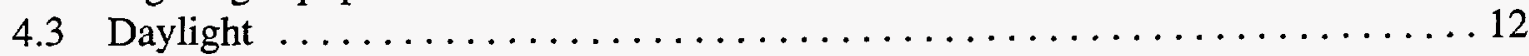

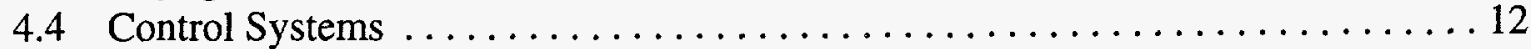

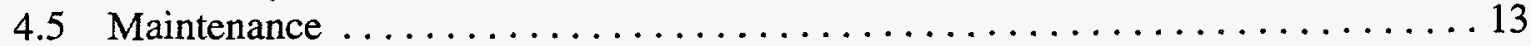

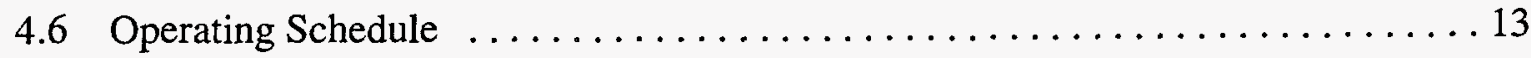

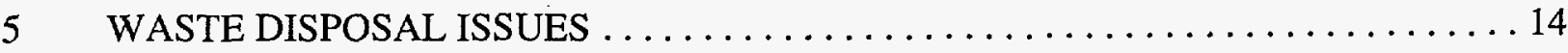

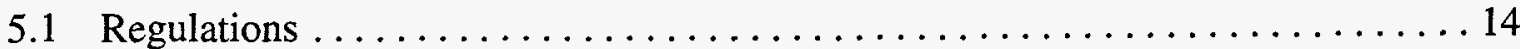

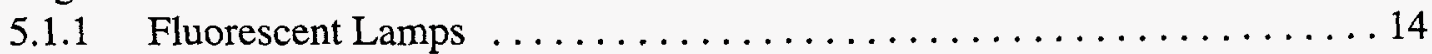

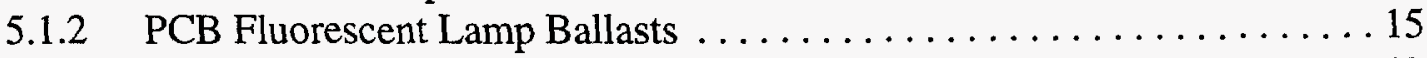

5.2 Cost Analysis for Disposal of Bulbs and Ballasts $\ldots \ldots \ldots \ldots \ldots \ldots \ldots \ldots 17$

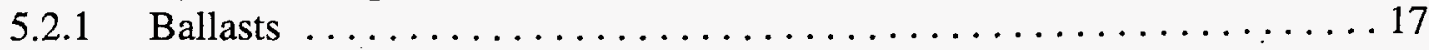




\section{CONTENTS (Cont.)}

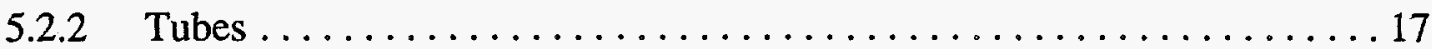

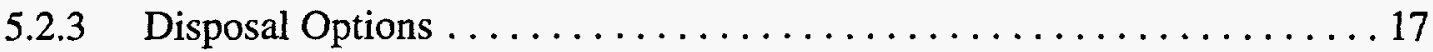

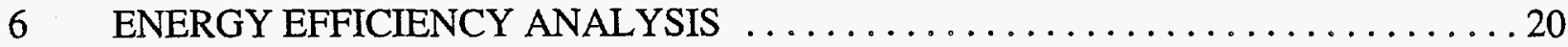

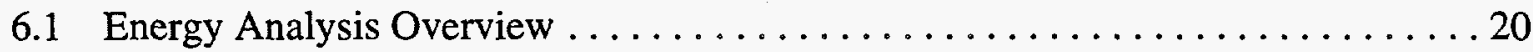

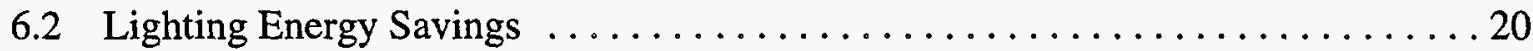

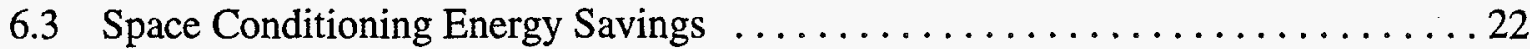

6.3 .1 Cooling System Savings . . . . . . . . . . . . . . . . . . . . 22

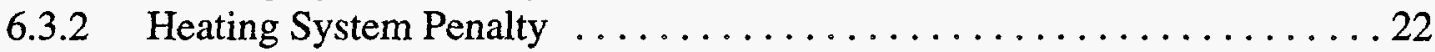

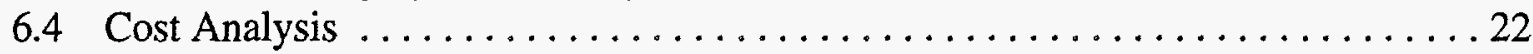

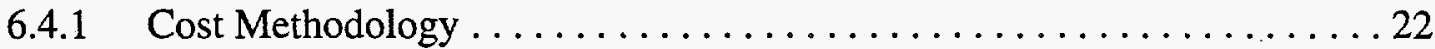

6.4.2 Existing Component Replacement Cost ...................25

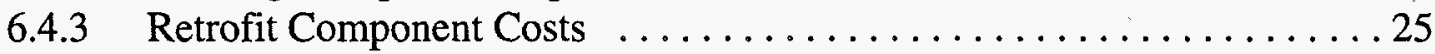

6.4.4 Cost Calculations for Interior and Exterior Buildings $\ldots \ldots \ldots \ldots \ldots 25$

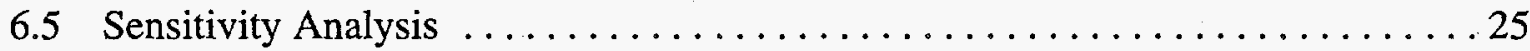

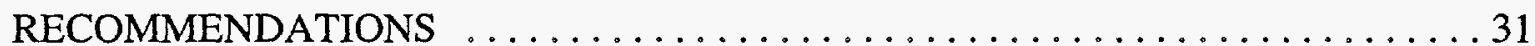

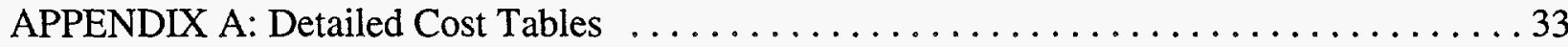

APPENDIX B: Fluorescent Lamp and Ballast Recyclers $\ldots \ldots \ldots \ldots \ldots \ldots \ldots \ldots \ldots$

APPENDIX C: EPA Information on Fluorescent Lamp Disposal $\ldots \ldots \ldots \ldots \ldots \ldots 6$

\section{TABLES}

1 Room Types and Lighting Usage $\ldots \ldots \ldots \ldots \ldots \ldots \ldots \ldots \ldots \ldots \ldots \ldots \ldots \ldots \ldots \ldots$

$2 \quad$ Areas Requiring Some Heating $\ldots \ldots \ldots \ldots \ldots \ldots \ldots \ldots \ldots \ldots \ldots$

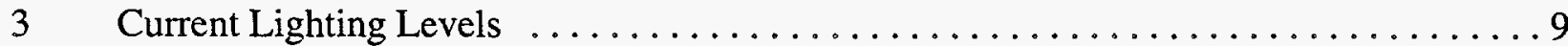

$4 \quad$ Summary of Lighting Fixtures in Interior Buildings $\ldots \ldots \ldots \ldots \ldots \ldots \ldots \ldots$

$5 \quad$ Disposal Costs . . . . . . . . . . . . . . . . . . . . . . . . . . . . . . . . 19

6 Specifications for Three Levels of Retrofit ....................... 20

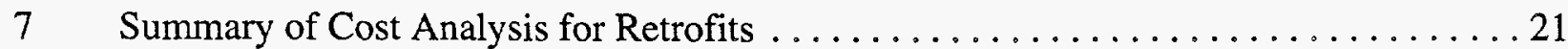




\section{TABLES (Cont.)}

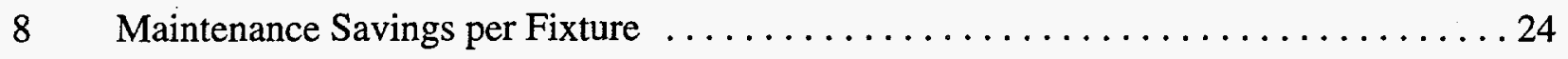

9 Costs for Existing Component Replacement $\ldots \ldots \ldots \ldots \ldots \ldots \ldots \ldots \ldots$

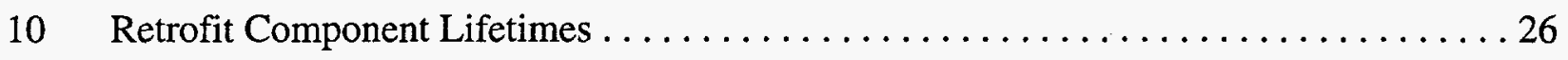

11 Summary of Cost Analysis for Minimal Retrofit Option $\ldots \ldots \ldots \ldots \ldots \ldots 27$

12 Summary of Cost Analysis for Intermediate Retrofit Option $\ldots \ldots \ldots \ldots \ldots \ldots \ldots 28$

13 Summary of Cost Analysis for Advanced Retrofit Option $\ldots \ldots \ldots \ldots \ldots \ldots \ldots 29$

A.1 Overall Cost Savings from Using Retrofit Options at CMAS $\ldots \ldots \ldots \ldots \ldots \ldots$

A.2 Cost Savings from Using Retrofit Options at Building $1 \ldots \ldots \ldots \ldots \ldots \ldots \ldots \ldots$

A.3 Cost Savings from Using Retrofit Options at Building $2 \ldots \ldots \ldots \ldots \ldots \ldots \ldots$

A.4 Cost Savings from Using Retrofit Options at Building $3 \ldots \ldots \ldots \ldots \ldots \ldots$

A.5 Cost Savings from Using Retrofit Options at Building $4 \ldots \ldots \ldots \ldots \ldots \ldots$

A.6 Cost Savings from Using Retrofit Options at Building $5 \ldots \ldots \ldots \ldots \ldots \ldots \ldots$

A.7 Cost Savings from Using Retrofit Options at Building $6 \ldots \ldots \ldots \ldots \ldots \ldots$

A.8 Cost Savings from Using Retrofit Options at Building $7 \ldots \ldots \ldots \ldots \ldots \ldots \ldots$

A.9 Cost Savings from Using Retrofit Options at Building $8 \ldots \ldots \ldots \ldots \ldots \ldots \ldots 4$

A.10 Cost Savings from Using Retrofit Options at Building $9 \ldots \ldots \ldots \ldots \ldots \ldots$

A.11 Cost Savings from Using Retrofit Options at Building $10 \ldots \ldots \ldots \ldots \ldots \ldots$

A.12 Cost Savings from Using Retrofit Options at Building $11 \ldots \ldots \ldots \ldots \ldots \ldots$

A.13 Cost Savings from Using Retrofit Options at Building $101 \ldots \ldots \ldots \ldots \ldots \ldots$

A.14 Cost Savings from Using Retrofit Options at Building $617 \ldots \ldots \ldots \ldots \ldots . \ldots 49$

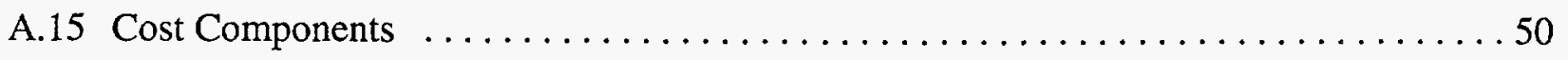

B.1 Fluorescent Lamp and Ballast Recyclers $\ldots \ldots \ldots \ldots \ldots \ldots \ldots \ldots \ldots \ldots \ldots \ldots \ldots \ldots \ldots \ldots$ 


\section{FIGURE}

1 Sensitivity of Payback to Electricity Rate 


\title{
LIGHTING ENERGY EFFICIENCY OPPORTUNITIES AT CHEYENNE MOUNTAIN AIR STATION
}

\author{
by \\ J.C. Molburg, A.J. Rozo, J.K. Sarles, R.A. Haffenden, \\ P.R. Thimmapuram, and J.D. Cavallo

\section{PROJECT OVERVIEW AND BACKGROUND}

\subsection{BACKGROUND}

Each year, Cheyenne Mountain Air Station (CMAS) consumes approximately 43 million kilowatt-hours $(\mathrm{kWh})$ of electrical energy, primarily for space conditioning, lighting, and communications systems. It now purchases most of this power from the local utility, at a cost of about $4 \notin / \mathrm{kWh}$. A declining fraction, currently about one-third, is self-generated, at a cost of about $14 \phi / \mathrm{kWh}$. Given the current share of self-generation, CMAS's annual power cost is about \$3.1 million. Even though the continuing shift to grid power will result in substantial savings, additional savings could be realized through improvements in lighting energy efficiency. Such efficiency improvements would also offer two indirect benefits: (1) reduced need for fuel if grid power were to become unavailable and (2) reduced number of local and regional environmental effects from CMAS operations.

In view of these potential benefits, Argonne National Laboratory (ANL) was asked to evaluate opportunities for lighting-related energy conservation at CMAS. The evaluation included an on-site inspection of current lighting systems, analysis of energy-efficient retrofit options, and investigation of the environmental effects that these lighting system retrofits could have when they are ready to be disposed of as waste. The project team is associated with ANL's Existing Buildings Efficiency Research Program. The work was done with the support of the CMAS Environmental Office.

\subsection{RESEARCH INTERESTS}

Because ANL seeks projects that extend the boundaries of technical analysis, its interest in the CMAS project, with its extraordinary operating environment, was high. Most of the buildings included in the project scope are located inside Cheyenne Mountain. Such a location has significant implications for lighting systems, particularly because the facility is operated 24 hours (h) per day. In addition, the CMAS Environmental Office expressed concern about the environmental effects that might result from the disposal of any materials associated with a retrofit program. This interest is consistent with one of ANL's strong program areas: environmental and regulatory research. 
The unusual environment and uses of CMAS offer an opportunity for further lightingrelated research that was not in scope of this study. In particular, the psychological effects of lighting systems as well as the effects of these systems on the health and performance of CMAS personnel could be studied. Aside from a consideration of color rendering and ambient noise, these issues have not been addressed.

\subsection{OBJECTIVES}

The overall objective was to estimate the potential energy and economic benefits available as a result of energy-efficient lighting retrofits. Retrofit options had to be consistent with environmental regulations and the maintenance of an effective work environment. The overall objective was to be achieved by completing a series of tasks to be identified during the project. The statement of work for the lighting audit and energy efficiency study at CMAS proposed six tasks. After the site survey on March 26-27, 1996, discussions with the lead CMAS environmental officer led to minor task revisions. The task descriptions listed below allow the original objectives to be accomplished but more precisely define the work to be undertaken.

1. Establish baseline electrical energy use.

2. Survey all areas (except where security restrictions apply) of the underground buildings and aboveground administrative facilities to assess existing light levels and existing equipment and the potential for energy savings from redesigning or retrofitting equipment. Categorize rooms and spaces according to how they are used.

3. Recommend up to three levels of retrofit for each usage category.

4. Estimate the life-cycle costs for each retrofit option. These estimates will cover the initial investment for materials and labor; cost for disposal of existing fixtures; and net energy, maintenance, and ultimate disposal costs.

5. Describe the advantages and disadvantages of each option, considering convenience, reliability, color rendering qualities, and lighting adequacy per Illuminating Engineering Society (IES) standards, in addition to the cost analysis.

6. Prepare a report on the analysis of the life-cycle and social costs of all existing and potentially cost-effective lighting systems, taking purchases, installation, maintenance, removal, and proper disposal into account. 


\subsection{SCOPE}

CMAS consists of 14 buildings and support facilities located inside the mountain and several administrative, security, and support buildings located outside. The interior buildings were of primary interest, although the scope of work was extended to include two exterior administrative buildings. Because of security restrictions, information on usage and current lighting was unavailable for several areas within the mountain. Lighting retrofit options were defined for each accessible area, and an analysis of the retrofit cost and energy savings was conducted for these options. Up to three options were evaluated for each room type. Options include task lighting, luminaire refurbishment or replacement, and automatic controls.

Costs for retrofit equipment, installation labor, and waste disposal were considered in the analysis. The figure of merit is simple payback - the quotient of net investment and annual cost savings. These savings include the direct savings from reduced lighting energy demand and the indirect savings from reduced cooling load attributable to reduced energy consumption by the lighting. A penalty for increased heating demand was also assigned. Maintenance and disposal cost savings or penalties for each retrofit option were included in the total savings figure.

\subsection{METHODOLOGY}

\subsubsection{Lighting Survey}

Basic lighting retrofit options are well-defined as a result of more than a decade of aggressive lighting retrofit programs. These basic options, which are listed in Section 4, have broad applicability. However, each facility is unique in terms of architectural features, existing lighting systems, daylight availability, usage patterns, and occupant preferences. The unique character of a given facility can only be captured by an on-site survey. On March 26 and 27, 1996, the project team performed a survey of accessible CMAS facilities. Findings of that survey are incorporated in the results and recommendations of this analysis. Each accessible room was surveyed for (1) current installed lighting fixture type and count, (2) current light levels, (3) primary room function, (4) occupant preferences and concerns, and (5) aptness of retrofit options. The survey was supplemented by reference to electrical system drawings to establish exact fixture specifications and counts.

\subsubsection{Analysis of Retrofit Options}

Current installed lighting energy consumption was estimated from the fixture count, fixture specifications, and operating hours. Each proposed retrofit option implies a room-by-room change 
in fixture specification and count. Lighting control options, such as motion detectors, imply a change in operating hours as well. These changes were reflected in calculated energy use under each retrofit option. The cost of retrofit was balanced against the energy savings (including heating and cooling effects) and maintenance and disposal savings in a simple payback calculation, which provides the figure of merit for evaluation of the retrofit options. Payback is simply the ratio of initial investment to annual reduction in energy and other costs. The initial investment included both equipment cost and installation labor. Calculations were implemented on spreadsheets (available on the CD-ROM version of this report), and a sensitivity analysis was conducted by marginally altering the price of electricity.

\subsubsection{Waste Disposal}

Fluorescent lamps contain small amounts of mercury, which has been shown to be hazardous to the environment and human health. In addition, ballasts can contain polychlorinated biphenyls (PCBs). Proper disposal of fluorescent lamps and ballasts has been researched for this project by Argonne lawyers specializing in environmental issues. This report describes proper disposal methods and provides a list (in Appendix B) of recyclers registered with the Ohio Environmental Protection Agency. 


\section{FACILITY DESCRIPTION}

\subsection{BUILDINGS AND ENVIRONS}

CMAS is located on the outskirts of Colorado Springs on and within Cheyenne Mountain at an elevation of $7,200 \mathrm{ft}$. Of the $335,000 \mathrm{ft}^{2}$ of building space, $201,000 \mathrm{ft}^{2}$ are in the 17 administrative buildings and $91,000 \mathrm{ft}^{2}$ are in industrial facilities. Fourteen buildings and facilities are within the mountain. The largest of these are three-story, steel structures similar in layout to conventional office buildings. Enclosed corridors connect all interior buildings. The facilities include open office spaces with dividers, individual offices, conference rooms, shops, medical facilities, exercise facilities, a commercial kitchen, a cafeteria, storage areas, and physical plant facilities. An ongoing program of facility maintenance and upgrades has resulted in a very diverse array of lighting systems.

The mountain interior provides a unique context for building energy systems. Although there is a complete absence of daylight, CMAS's need for lighting fixtures is only slightly greater than that of a conventional location, since lights are required for operation in nonperimeter spaces in any facility. The lack of daylight also does not increase the number of hours that the lights need to operate, since lights in most buildings are on even in daylight hours. However, the lack of daylight restricts design and retrofit options, which could normally exploit daylight. The unusual environment of the mountain interior also affects the interaction of the lighting and space conditioning system. Normally, lighting provides a substantial fraction of building heating energy and increases the air conditioning load substantially as well. Therefore, a reduction in lighting power consumption decreases the energy consumption for air conditioning but increases the demand for heat. The net benefit is a trade-off that reflects the relative demand for heating and for air conditioning in a particular setting. Although ANL has not studied CMAS's heating and cooling requirements in detail, CMAS environmental staff reported that very little heat is required, even in winter months. This situation could reflect a tempering effect of the mountain mass, reduction in wind-related heat loss, high occupancy, or the extensive lighting loads. In this case, the result is a favorable balance, in which reduced lighting power consumption will result in net savings in space conditioning.

\subsection{FACILITY USAGE}

The key issue with regard to facility usage is that the CMAS operates on a 24-h basis. It therefore experiences a full lighting load for roughly twice the number of hours as do typical commercial facilities. This situation therefore doubles the rate of payback for any lighting retrofit. The usage issue that is second in importance is the diversity of usage, which is described in some detail in Sections 3.1.1 and 6.1. 


\section{LIGHTING SURVEY}

\subsection{GENERAL FINDINGS}

\subsubsection{Room Types and Tasks}

Sixteen room types were defined according to the tasks that are performed in them. These room types, which are listed in Table 1, can be used to simplify the analysis of retrofit options by allowing generic options to be specified for each room type. In addition, the survey burden is reduced because information from one room can be extrapolated to other rooms of the same type that were not accessible for the survey.

TABLE 1 Room Types and Lighting Usage

\begin{tabular}{llr}
\hline \multicolumn{1}{c}{ Room Type } & \multicolumn{1}{c}{ Lighting Used } & $\begin{array}{c}\text { Number of } \\
\text { Hours }\end{array}$ \\
\hline Corridors & Primarily fluorescent, with some incandescent & 24 \\
Stairwells & Fluorescent & 24 \\
Tunnels & Incandescent & 24 \\
Caverns & High-intensity discharge (HID) & 24 \\
Storage & Fluorescent & 8 \\
Bathrooms & Combination of fluorescent and incandescent & 12 \\
Mechanical rooms & Combination of fluorescent and incandescent & 4 \\
Open office & Primarily fluorescent & 8 \\
Private office & Primarily fluorescent & 8 \\
Conference rooms & Combination of fluorescent and incandescent & 6 \\
Dining rooms & Combination of fluorescent and incandescent & 6 \\
Control rooms & Primarily fluorescent & 24 \\
Computer rooms & Fluorescent & 24 \\
Maintenance shops & Fluorescent & 12 \\
Medical rooms & Fluorescent & 24 \\
\hline
\end{tabular}




\subsubsection{Lighting Retrofit Concerns}

The lighting survey team was introduced to room occupants, many of whom seemed to view the prospect of a lighting retrofit with some concern. In general, they were very satisfied with the current lighting systems and perceived that lighting levels would be reduced by the retrofit. The occupants were assured that this was not the intention. Nevertheless, it is common practice in lighting retrofits to reduce lighting levels in over-lighted areas. Two situations call for such lighting reductions. One is where current lighting is excessive for the tasks at hand. The other is where general or background lighting can be reduced and replaced with task lighting. (The complete absence of daylight in the interior buildings may be a psychological factor to be considered when deciding whether to retrofit, but such considerations were outside the scope of this analysis.)

Some occupants were more enthusiastic about the prospect of a lighting retrofit, identifying specific needs or shortcomings in the existing system and expressing support for the energy savings motive. Some specific requests were for (1) improved task lighting in the medical examination facilities, (2) glare reduction in central computing facilities, and (3) reduced background lighting in some office areas with high computer usage. Other concerns included light color rendition, audible ballast hum, and harmonic interference with existing electrical system operations.

\subsubsection{Current Lighting Systems and Levels}

Current lighting levels were found to be adequate to excessive, except in some areas affected by shadowing caused by partitions and a few areas with lamps that were not operating. Many areas also experienced lighting well below system design levels because of the deterioration of plastic diffusers, dirt accumulation, and lamp aging. Table 1 provides more specifics. The fact that existing lighting systems were largely below original design effectiveness yet remained adequate suggests that less installed wattage could be used, particularly if the retrofit fixtures are more regularly maintained or less prone to deterioration.

Lighting system upgrading had accompanied CMAS building renovations, even though energy conservation had not been the focus of these upgrades. The renovated areas, which incorporate more effective and more efficient systems, have provided an in-house example of how efficiency can be served without compromising lighting adequacy.

Most general office areas had adequate lighting for accomplishing office tasks without a need for supplemental, or task, lighting. However, shadowing caused by partitions did create a need for some task lighting, which was provided by shelf-mounted fluorescent fixtures. 


\subsubsection{Heating and Cooling}

As described above, lighting systems affect heating and cooling loads. Therefore, the survey included discussions with site engineers to characterize the heating and cooling systems and their typical operating profiles. In general terms, industrial areas (those with mechanical equipment) do not require heat. Most building areas are primarily offices and do require some heat during the winter. Table 2 lists the building areas that require some heating. Specific operating hours for the heating system were not available, so the heating hours are handled parametrically in the analysis.

\subsection{SPECIFIC DATA}

\subsubsection{Lighting Levels}

Light meter readings were taken in the surveyed rooms. These readings and the IES standards for the tasks performed in those rooms are summarized in Table 3.

\subsubsection{Fixture Inventory}

A fixture inventory was taken as part of the survey. Time did not permit examination of each fixture to verify ballast type and bulb specifications, but the survey results, supplemented by data from engineering drawings of the lighting systems, have provided an accurate estimate of current installed lighting. The detailed inventory appears in Appendix A. Table 4 provides a summary of the fixture inventory. 
TABLE 2 Areas Requiring Some Heating

\begin{tabular}{ll}
\hline Bldg. & \multicolumn{1}{c}{ Heat Required } \\
\hline 3 & $\begin{array}{l}\text { All three floors require some heat, although not } \\
\text { much heating demand is expected }\end{array}$ \\
4 & Some heat demand occurs in Oct.-May \\
5 & Third floor only requires heat; very little is required \\
6 & Office areas require some heat \\
7 & Office areas require some heat \\
8 & This is being converted to office areas and will \\
9 & require some heat \\
10 & First floor only requires heat \\
11 & Office areas require some heat \\
12 & Third floor only requires some heat \\
\hline
\end{tabular}

TABLE 3 Current Lighting Levels

\begin{tabular}{llcc}
\hline \multicolumn{1}{c}{ Room Type } & \multicolumn{1}{c}{ Example Room } & $\begin{array}{c}\text { Meter Readings } \\
\text { (foot-candles) }\end{array}$ & IES Standard \\
\hline Corridors & In Bldg. 1, third floor & $5-10$ & $5-10$ \\
Stairwells & In Bldg. 1 & $15-20$ & $10-20$ \\
Tunnels & At Bldg. 4 entrance & $15-30$ & $5-10$ \\
Caverns & At entrance to facility & $50-60$ & None \\
Storage & Rooms 4204, 4201, and 12107 & $25-65$ & $50-100$ \\
Bathrooms & Room 4207 & $30-40$ & $5-10$ \\
Mechanical rooms & Room 1106 & $15-25$ & $15-20$ \\
Open office & Room 4102 & $20-30$ & $30-50$ \\
Private office & Room 4102B & $30-50$ & $30-50$ \\
Dining rooms & Room 1309 & $35-55$ & $40-50$ \\
Control rooms & & Lights on dimmer & \\
& & controls & $25-30$ \\
Computer rooms & Room 2101 & $95-100$ & $500-750$ \\
Maintenance shops & Room 4105 & $450-600$ & $50-75$ \\
Medical rooms & Room 1205 & $45-55$ & \\
\hline
\end{tabular}


TABLE 4 Summary of Lighting Fixtures in Interior Buildings ${ }^{a}$

\begin{tabular}{lrrrrrrr}
\hline & \multicolumn{3}{c}{ Fluorescent per Type of Fixture } & & \multicolumn{2}{c}{ Incandescent } \\
\cline { 3 - 4 } \cline { 7 - 8 } Bldg. & 1-Lamp & 2-Lamp & 3-Lamp & 4-Lamp & & $<100 \mathrm{~W}$ & $>100 \mathrm{~W}$ \\
\hline & & & & & & & \\
1 & 161 & 136 & 71 & 26 & & 73 & 59 \\
2 & 24 & 94 & 3 & 75 & & 22 & 79 \\
3 & 9 & 73 & 7 & 207 & & 3 & 84 \\
4 & 45 & 180 & 6 & 28 & & 17 & 45 \\
5 & 22 & 105 & 9 & 1 & & 21 & 17 \\
6 & 30 & 36 & 0 & 28 & & 20 & 5 \\
7 & 24 & 92 & 0 & 4 & & 34 & 20 \\
8 & 6 & 122 & 0 & 66 & & 31 & 15 \\
9 & 30 & 239 & 0 & 40 & & 18 & 31 \\
10 & 14 & 65 & 0 & 43 & & 13 & 18 \\
11 & 23 & 222 & 64 & 0 & & 19 & 30 \\
Total & 388 & 1,364 & 160 & 518 & 271 & 403 \\
\hline
\end{tabular}

a This table lists most, but not all, of the existing fixtures and includes the most likely retrofit candidates. Exit lighting and some other special-purpose lighting are excluded. 


\section{GENERAL RETROFIT OPTIONS}

The lighting system retrofit encompasses a broad spectrum of activities, from replacing bulbs to using automatic controls to changing room or building usage. This section provides a context for the retrofit options that ANL has analyzed by listing the full spectrum of retrofit activities identified in the IES lighting ready reference document. Although some of these activities are not applicable to CMAS, it is useful to itemize the full set of activities from which recommended options have been built. The descriptions here are from the referenced IES publication. Some are taken verbatim from its checklist of energy-saving lighting ideas.

\subsection{TASK LIGHTING}

The basic concept of task lighting is to reduce the total lighting load by providing lighting as required for a particular task. General background lighting can be reduced to levels required for safety or aesthetics. A related opportunity is to reduce current lighting where it exceeds that required for the task at hand. Only in extreme cases is task lighting to be provided in areas with no visual task requirements. Identifying such opportunities requires a detailed review of daily operations, which could not be done under the scope of this study. Solutions include reducing general lighting and supplementing it with task lighting, grouping work areas according to task, isolating unused areas to eliminate lighting use, removing stacks or lighting obstructions, lowering luminaires, relocating luminaires, eliminating partitions (which cause shadows), and using light-colored room surface treatments.

Among the concerns raised by these approaches are that (1) the lighting system operating costs are a secondary consideration to effective task performance, and reorganization of work spaces must consider performance factors first, and (2) very specific lighting system designs reduce the flexibility of space utilization options.

\subsection{LIGHTING EQUIPMENT}

The focus of the analysis was on lighting equipment options for energy conservation, primarily the retrofit of more efficient fixtures and lamps. However, lighting equipment options include more than lamp and fixture retrofit and replacement. One important option is to upgrade luminaire maintenance through regular washing and replacement cycles. A maintenance schedule is nearly as important as an equipment retrofit program. Equipment replacement options include these:

- Use lamps with higher output per watt input. 
- Replace a group of low-wattage incandescents with fewer high-wattage lamps.

- Use reflector (R), parabolic aluminized reflector (PAR), or $\mathrm{ER}^{1}$ lamps to obtain required light with lower wattage.

- Use reduced-current ballasts.

- Use low-maintenance luminaires.

- Use ballasts that can accommodate high-pressure sodium or metal halide lamps.

- Use multilevel ballasts to allow for intermittent reduction in light.

- Substitute high-pressure sodium lamps for existing mercury lamps (retrofit ballast is required).

- Use heat removal luminaires to reduce the operating temperature of the lamp and excess heat in occupied space.

\subsection{DAYLIGHT}

The exterior buildings would better exploit outside daylight if the lighting near daylight areas could be reduced. The most demanding visual tasks could be located near sources of daylight. Window treatments could be modified to better use daylight. However, the use of daylight must be evaluated in the context of its effect on heating and cooling loads, since overall energy efficiency might require restrictions on peak "daylighting."

\subsection{CONTROL SYSTEMS}

The most basic control system option for improving efficiency is to install selective switching, so that lighting for small areas can be independently controlled. Switches and dimmers can be installed to provide the flexibility required for spaces with alternative visual tasks. Conference rooms at CMAS have such systems. Flexibility can also be provided with plug-in luminaires. These can accommodate changes in room use since they can be readily interchanged. Photocells provide

1 These designations refer to integral reactors. A PAR is often used in conjunction with a tungsten-halogen capsule in a flood lamp. This type of lamp is a convenient replacement for conventional incandescent lamps. 
on-off capability, particularly in response to varying daylight. Time switches can provide on-off functionality synchronized to work schedules. Manual alternatives include reminders to shut lights off and coding systems to remind crews of any preferred on-off schedule. Motion detectors and occupancy sensors provide an alternative to timer controls for rooms used irregularly. The most sophisticated control systems operate with low-voltage controls and computer supervision.

\subsection{MAINTENANCE}

The basic maintenance requirements are to replace bulbs, clean reflectors and diffusers, and repair failed components. Replacing failed luminaires with high-efficiency models as a matter of routine maintenance procedure is a relatively slow way of accomplishing a retrofit, but it has virtually no additional cost. Luminaires should be selected with consideration given to their rate of deterioration and maintenance requirements. New fluorescent fixtures with open grids, for example, deteriorate less quickly and accumulate less dirt than enclosed fixtures with plastic diffusers.

\subsection{OPERATING SCHEDULE}

Operating schedule options are a sophisticated version of "turn the lights off when you leave the room." They require a review of occupancy and use patterns. Some alternatives are to (1) schedule cleaning during rather than after operating hours, (2) restrict parking during low-use periods to specified lighted areas, and (3) educate occupants on the efficient operation of various lighting types. Incandescent lamps, for example, should be turned off immediately after use. Fluorescent lamps should be turned off if they are not needed for a period of more than 5 minutes. HID lamps should be turned off if they are not needed for 30 minutes or longer. 


\section{WASTE DISPOSAL ISSUES}

\subsection{REGULATIONS}

\subsubsection{Fluorescent Lamps}

Currently in Colorado, fluorescent lamps that contain mercury may be a hazardous waste under the Resource Conservation and Recovery Act (RCRA). According to the Colorado Code of Regulations (CCR), the generator of the waste is responsible for determining if the waste bulbs demonstrate the characteristic of toxicity (6 CCR $262.11 ; 261.24)$. If the waste fails the toxicity characteristic leaching procedure (TCLP) test for mercury $(0.02 \mathrm{mg} / \mathrm{L})$, it would be considered a hazardous waste. ${ }^{2}$

Therefore, as a hazardous waste, lamps may be accumulated at or near the point of generation in an amount less than the equivalent of 55 gal, as long as the containers are compatible, in good condition, and labeled with the words "hazardous waste" or other words describing the contents (e.g., "waste fluorescent lamps"). As long as the waste does not exceed the 55-gal limit, there is no time limit on the accumulation of the lamps. However, if the number of bulbs exceeds the equivalent of $55 \mathrm{gal}$, the waste must comply with generator standards. These allow hazardous waste in any amount to be stored for 90 days, as long as the containers are compatible, in good condition, and labeled with the words "hazardous waste." The storage area must be supervised by a trained manager who performs weekly inspections. The area must be maintained to prevent release of the hazardous waste, and there must be emergency response planning for the area.

If storage of the waste lamps is to exceed the 55-gal and 90-day limits, the storage area has to obtain a treatment, storage, and/or disposal facility permit from the Colorado Department of Public Health and the Environment (CDPHE), and the storage facility has to comply with all the siting, security, design, and operation requirements for a permitted facility.

Shipment of waste lamps off site to a treatment or disposal facility requires the use of a hazardous waste manifest containing the name of the RCRA-authorized shipper and the properly permitted destination facility. A copy of the manifest, signed by the receiving facility, must be returned to the Defense Reutilization and Marketing Office (DRMO) at Fort Carson, Colorado, within 35 days. The manifested shipment must be accompanied by a Certificate of Land Disposal

2 The generator may also declare the waste a hazardous waste without chemical analysis, on the basis of process knowledge. However, a treatment, storage; or disposal facility may require a chemical analysis to accept the waste. 
Restriction containing the information that the treatment or disposal facility needs to allow proper land disposal of the waste.

The CDPHE's policy prefers recycling to treatment and disposal (Cathy Hadivek, CDPHE, telephone conversation with R. Haffenden, ANL, May 7, 1996). If lamps are to be recycled, crushing (as a necessary step of a legitimate recycling process) is exempt under RCRA Section 261.6(c). Crushing activities may occur at the generator's or recycler's facility and still remain exempt. However, the generator must ensure that the crushed bulbs are ultimately recycled and not disposed of in a landfill (EPA, Office of Solid Waste and Emergency Response, letter on crushing of mercurycontaining lamps, to RCRA Compliance Branch, Land Division, Alabama Department of Environment, June 5, 1995). Appendix B contains information from a publication by the State of Ohio EPA listing U.S. fluorescent lamp recyclers.

In Colorado, crushing waste lamps in accumulation tanks or containers to make them more suitable for recycling or reclamation or to reduce their volume or toxicity is permitted by 6 CCR 1007-3, Section 110.21(d)(1). However, the mercury vapor must be captured by the treatment process. Also, the generator must comply with all generator standards and must file a Notification and Waste Analysis Plan with the CDPHE 30 days before beginning the treatment activity. Therefore, the Colorado generator may crush the waste lamps to consolidate them for disposal or recycling.

\subsubsection{PCB Fluorescent Lamp Ballasts}

If the ballasts are not leaking, they are considered solid waste under the Toxic Substance Control Act (TSCA) and can be disposed of in a solid waste landfill, with the permission of the landfill operator. ${ }^{3}$ They do not have to be shipped with a manifest, and there is no time limit on storage pending disposal.

If the ballasts are leaking, they must be disposed of in an EPA-approved PCB incinerator, according to TSCA. Leaking PCB ballasts must be in drums clearly labeled with the words "caution: contains PCBs" on a yellow label (40 CFR 761.40) and must bear the name and address of the generator, weight, the date the ballasts were first removed from service, a description (e.g., RQ

3 A PCB small capacitor may be disposed of as municipal solid waste (40 CFR 761.60(b)(2)(ii)). A small

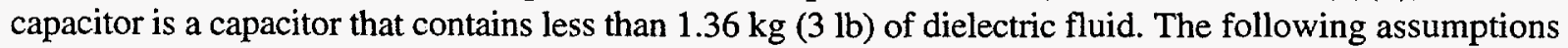
may be used if the actual weight of the dielectric fluid is unknown. A capacitor whose total volume is less

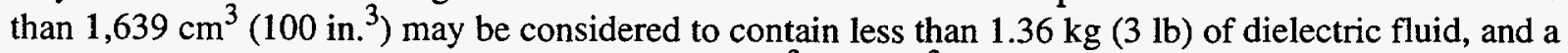
capacitor whose total volume is more than $3,278 \mathrm{~cm}^{3}\left(200 \mathrm{in}^{3}\right)$ may be considered to contain more than $1.36 \mathrm{~kg}(3 \mathrm{lb})$ of dielectric fluid. A capacitor whose volume is between 1,639 and $3,278 \mathrm{~cm}^{3}$ may be considered to contain less than $1.36 \mathrm{~kg}(3 \mathrm{lb})$ of dielectric fluid if the total weight of the capacitor is less than $4.08 \mathrm{~kg}(9 \mathrm{lb})$. 
Polychlorinated Biphenyls, 9, UN231.5, PG II), and a unique container tracking number. Leaking ballasts must be shipped with a hazardous waste manifest. The generator must receive a certificate of disposal from the disposal facility.

The CDPHE encourages generators to use TSCA incineration facilities for the disposal of all PCB articles (leaking and nonleaking) because such facilities handle the waste in an appropriate manner (Cathy Hadivek, CDPHE, telephone conversation with R. Haffenden, ANL, May 8, 1996). Incineration is costly, but as a result of using the approved methodology, the generator will not have the long-term liability associated with drums that contain a large quantity of ballasts that are releasing PCBs to a landfill. ${ }^{4}$ Under the Comprehensive Environmental Response, Compensation and Liability Act of 1980 (CERCLA), anyone disposing of more than $1 \mathrm{lb}$ of PCBs or mercury in any landfill is a potentially responsible party in any subsequent Superfund cleanup of that landfill.

If leaking PCB small capacitors are to be stored pending disposal, storage areas must comply with the TSCA requirements. Compliance includes having an adequate roof and walls to prevent rain from entering and an impervious floor with continuous curbing of 6 in. and no drains, expansion joints, or other openings. The storage area must be properly placarded and inspected every 30 days for leaking articles or containers. All containers and articles must also be marked with the date they were removed from service.

Many facilities maintain an annual document $\log$ that includes all manifests and certificates of disposal and identifies each PCB article placed in storage. ${ }^{5}$ For shipments of leaking capacitors, which require a manifest to an EPA-approved TSCA disposal facility, the generator must maintain the final signed manifests and certificates of disposal for each shipment of PCBs for three years.

4 Contact the EPA regional office to ascertain its definition of "large quantities." Usually, if a combined amount of $3 \mathrm{lb}$ or more of PCBs is contained in a number of small capacitors, the capacitors should be managed as large capacitors, which includes being disposed of by incineration (see PCB Question and Answer Guide, 1994 edition, published by the EPA, Operations Branch, Chemical Management Division, Office of Pollution Prevention and Toxics).

5 This requirement applies only to owners or operators of a facility that stores at any one time at least $45 \mathrm{~kg}$ (99.4 lb) of PCBs contained in containers, or one or more PCB transformers, or 50 or more PCB large highvoltage or low-voltage capacitors. A storage facility that stores only small capacitors would not be required to keep such a log. 


\subsection{COST ANALYSIS FOR DISPOSAL OF BULBS AND BALLASTS}

\subsubsection{Ballasts}

The following guidelines should be used to determine if ballasts contain PCBs:

1. All ballasts manufactured through 1979 contain PCBs.

2. Ballasts manufactured after 1979 are assumed to contain PCBs unless labeled "no PCBs."

In Colorado, PCB-containing ballasts must be handled and disposed of as hazardous waste. Hazardous waste disposal from CMAS is handled by the Fort Carson DRMO. Intact, nonleaking, non-PCB ballasts may be disposed of as solid waste. PCB-containing ballasts that have been damaged and are leaking require special handling and must be incinerated in an EPA-approved, high-temperature incinerator.

\subsubsection{Tubes}

Fluorescent light tubes contain mercury, which, under RCRA, demonstrates the characteristic of hazardous waste (D009). The disposal of mercury-containing waste is regulated by the EPA under 40 CFR 261. Such waste must be tested to determine proper handling requirements. The number of tests being performed must be sufficient to ensure a valid classification of each type of tube being discarded. If the tubes pass a TCLP test, they can be disposed of in any municipal solid waste landfill. If the tubes fail, they must be handled as hazardous waste and disposed of through the Fort Carson DRMO.

The CMAS solid waste contractor, Waste Management of Southern Colorado, has disposed of fluorescent tubes as solid waste. After the tubes had passed TCLP tests, they were packaged to ensure safe handling and picked up as a special shipment.

\subsubsection{Disposal Options}

There are three disposition destinations for tubes and ballasts. Solid waste landfills can be used for non-PCB ballasts and tubes that pass the TCLP test. Hazardous waste can be disposed of through the Fort Carson DRMO for ultimate disposal in an approved hazardous waste treatment, storage, and disposal (TSD) facility. Alternatively, tubes and ballasts can be sent to a recycling 
facility. A list of companies that recycle fluorescent light bulbs was obtained from the CDPHE. The costs for the various options are presented in Table 5 and summarized below:

1. Recycle both tubes and ballasts: $\$ 7,643$.

2. Dispose of both tubes and ballasts as hazardous waste: $\$ 15,562$.

3. Dispose of tubes that have passed TCLP tests as solid waste for $\$ 313$ and dispose of all ballasts as hazardous waste for $\$ 7,000$ : $\$ 7,313$.

4. Dispose of tubes that have passed TCLP tests as solid waste for $\$ 313$ and recycle ballasts for $\$ 5,250$ plus $\$ 793: \$ 6,356$.

The calculations assume that all ballasts must be disposed of as hazardous waste. If some ballasts were labeled "no PCBs," disposal costs would decrease accordingly. Such non-PCB ballasts could also be recycled, but the cost of recycling is much higher than the cost of disposal as solid waste. However, a conservative assumption is that most ballasts are likely to require handling as hazardous waste. 
TABLE 5 Disposal Costs

\begin{tabular}{|c|c|c|c|c|c|c|c|c|c|}
\hline \multirow{2}{*}{$\begin{array}{l}\text { HW } \\
\text { Item }\end{array}$} & \multirow[b]{2}{*}{ Quantity } & \multicolumn{3}{|c|}{ Weight (lb) } & \multicolumn{2}{|c|}{$\begin{array}{l}\text { Cost of HW } \\
\text { Disposal }(\$) \\
\end{array}$} & \multicolumn{2}{|c|}{$\begin{array}{c}\text { Cost of HW } \\
\text { Recycling (\$) }\end{array}$} & \multirow{2}{*}{$\begin{array}{c}\text { Savings } \\
(\%)\end{array}$} \\
\hline & & Each & Packing & Total & Pound & Total & per Item & Total & \\
\hline Tube & 5,000 & 0.63 & 1.25 & 6,250 & 1.37 & 8,563 & $0.32 /$ unit & 1,600 & 81 \\
\hline \multirow[t]{2}{*}{ Ballast } & 2,500 & 3.25 & 3.50 & 8,750 & 0.80 & 7,000 & $0.60 / \mathrm{lb}$ & 5,250 & 25 \\
\hline & & & & & & & Other charge & 793 & \\
\hline \multirow[t]{2}{*}{ Total } & & & & & & 15,562 & & 7,643 & 51 \\
\hline & & & Weight (lb & & \multicolumn{2}{|c|}{$\begin{array}{l}\text { Cost of SW } \\
\text { Disposal }(\$)\end{array}$} & & & \\
\hline $\begin{array}{l}\text { SW } \\
\text { Item } \\
\end{array}$ & Quantity & Each & $\begin{array}{c}\text { with } \\
\text { Packing }\end{array}$ & Total & $\begin{array}{c}\text { per } \\
\text { Pound } \\
\end{array}$ & Total & & & \\
\hline Tube & 5,000 & 0.63 & 1.25 & 6,250 & $0.05 / \mathrm{lb}$ & 312 & & & \\
\hline Total & & & & & & 313 & & & \\
\hline
\end{tabular}

a $\mathrm{HW}=$ hazardous waste, $\mathrm{SW}=$ solid waste. 


\section{ENERGY EFFICIENCY ANALYSIS}

\subsection{ENERGY ANALYSIS OVERVIEW}

The analysis of energy usage under the different retrofit options was conducted by means of spreadsheets designed specifically for this purpose. The spreadsheets are provided on the CDROM version of this report. They may also be requested upon written request. Summary tables of the cost savings are provided as Tables A.1-A.14 in Appendix A. Table 6 shows the options for retrofit considered for each fixture or control.

\subsection{LIGHTING ENERGY SAVINGS}

Analysts strongly believe that total cost savings should be considered when decisions related to a proposed lighting retrofit are being made. However, they may view maintenance savings separately. For these reasons and to facilitate decisions, the payback periods for the retrofit options were separated. Table 7 shows the retrofit payback periods, with and without estimated maintenance savings. Interior and exterior buildings are treated separately.

TABLE 6 Specifications for Three Levels of Retrofit

\begin{tabular}{|c|c|c|c|}
\hline Existing System & Minimal Retrofit & Intermediate Retrofit & Advanced Retrofit \\
\hline $\begin{array}{l}\mathrm{T}-12,40-\mathrm{W} \text { fluorescent } \\
\text { 1-lamp fixture }\end{array}$ & $\begin{array}{l}\text { Replace with T-12, } \\
34-W \text { fluorescent }\end{array}$ & $\begin{array}{l}\text { Replace with } \mathrm{T}-8,32-\mathrm{W} \\
\text { fluorescent with } \\
\text { electronic ballast in } \\
\text { existing luminaire }\end{array}$ & $\begin{array}{l}\text { Replace with } \mathrm{T}-8,32-\mathrm{W} \\
\text { fluorescent with electronic } \\
\text { ballast, parabolic reflectors }\end{array}$ \\
\hline 2-lamp fixture & $\begin{array}{l}\text { No change in lamp } \\
\text { count }\end{array}$ & No change in lamp count & $\begin{array}{l}\text { Replace with } 1 \text {-lamp } \\
\text { fixtures with added task } \\
\text { lighting }\end{array}$ \\
\hline 3- and 4-lamp fixtures & $\begin{array}{l}\text { No change in lamp } \\
\text { count }\end{array}$ & No change in lamp count & $\begin{array}{l}\text { Replace with } 2 \text {-lamp } \\
\text { fixtures with added task } \\
\text { lighting }\end{array}$ \\
\hline Incandescent, $<100 \mathrm{~W}$ & No change & $\begin{array}{l}\text { Replace with compact } \\
\text { fluorescent }\end{array}$ & $\begin{array}{l}\text { Replace with compact } \\
\text { fluorescent }\end{array}$ \\
\hline Incandescent, $>100 \mathrm{~W}$ & No change & $\begin{array}{l}\text { Replace with PAR } 38 \\
\text { floods }\end{array}$ & $\begin{array}{l}\text { Replace with PAR } 38 \\
\text { floods }\end{array}$ \\
\hline Switch control only & No change & $\begin{array}{l}\text { Add motion detectors in } \\
\text { selected storage facilities }\end{array}$ & $\begin{array}{l}\text { Add motion detectors in } \\
\text { selected storage and } \\
\text { industrial facilities and in } \\
\text { small offices }\end{array}$ \\
\hline
\end{tabular}




\section{TABLE 7 Summary of Cost Analysis for Retrofits}

a. Interior Buildings without Maintenance Savings

\begin{tabular}{|c|c|c|c|c|c|c|}
\hline \multirow[b]{2}{*}{ Retrofit } & \multicolumn{4}{|c|}{ Annual Amount (\$) } & \multirow[b]{2}{*}{$\begin{array}{l}\text { Retrofit } \\
\text { Cost }(\$)\end{array}$} & \multirow[b]{2}{*}{$\begin{array}{c}\text { Payback } \\
\text { Period (yr) }\end{array}$} \\
\hline & $\begin{array}{c}\text { Lighting } \\
\text { Saved }\end{array}$ & $\begin{array}{l}\text { Cooling } \\
\text { Saved }\end{array}$ & $\begin{array}{l}\text { Heating } \\
\text { Penalty }\end{array}$ & $\begin{array}{l}\text { Total } \\
\text { Saved }\end{array}$ & & \\
\hline Minimal & 12,544 & 3,950 & 683 & 15,811 & 69,351 & 4.39 \\
\hline Moderate & 41,746 & 13,147 & 2,277 & 52,616 & 197,831 & 3.76 \\
\hline Advanced & 69,724 & 21,959 & 3,803 & 87,880 & 235,503 & 2.68 \\
\hline
\end{tabular}

Annual Amount (\$)

\begin{tabular}{lcrrrrrr}
\cline { 2 - 4 } \multicolumn{1}{c}{ Retrofit } & $\begin{array}{c}\text { Lighting } \\
\text { Saved }\end{array}$ & $\begin{array}{c}\text { Cooling } \\
\text { Saved }\end{array}$ & $\begin{array}{c}\text { Heating } \\
\text { Penalty }\end{array}$ & $\begin{array}{c}\text { Maintenance } \\
\text { Saved }\end{array}$ & $\begin{array}{r}\text { Total } \\
\text { Saved }\end{array}$ & $\begin{array}{r}\text { Retrofit } \\
\text { Cost }(\$)\end{array}$ & $\begin{array}{c}\text { Payback } \\
\text { Period (yr) }\end{array}$ \\
\hline Minimal & 12,544 & 3,950 & 683 & 19,840 & 35,651 & 69,351 & 1.95 \\
Moderate & 41,746 & 12,147 & 2,277 & 81,075 & 133,691 & 197,831 & 1.48 \\
Advanced & 69,724 & 21,959 & 3,803 & 82,295 & 170,175 & 235,503 & 1.38
\end{tabular}

c. Exterior Buildings without Maintenance Savings

\begin{tabular}{|c|c|c|c|c|c|c|}
\hline \multirow[b]{2}{*}{ Retrofit } & \multicolumn{4}{|c|}{ Annual Amount (\$) } & \multirow[b]{2}{*}{$\begin{array}{l}\text { Retrofit } \\
\text { Cost }(\$)\end{array}$} & \multirow[b]{2}{*}{$\begin{array}{l}\text { Payback } \\
\text { Period (yr) }\end{array}$} \\
\hline & $\begin{array}{l}\text { Lighting } \\
\text { Saved }\end{array}$ & $\begin{array}{l}\text { Cooling } \\
\text { Saved }\end{array}$ & $\begin{array}{l}\text { Heating } \\
\text { Penalty }\end{array}$ & $\begin{array}{l}\text { Total } \\
\text { Saved }\end{array}$ & & \\
\hline Minimal & 2,039 & 642 & 111 & 2,570 & 11,055 & 4.30 \\
\hline Moderate & 3,713 & 1,169 & 203 & 4,679 & 11,498 & 2.46 \\
\hline Advanced & 7,144 & 2,250 & 390 & 9,004 & 19,492 & 2.16 \\
\hline
\end{tabular}

Annual Amount (\$)

\begin{tabular}{lccccrrr} 
Retrofit & $\begin{array}{c}\text { Lighting } \\
\text { Saved }\end{array}$ & $\begin{array}{c}\text { Cooling } \\
\text { Saved }\end{array}$ & $\begin{array}{c}\text { Heating } \\
\text { Penalty }\end{array}$ & $\begin{array}{c}\text { Maintenance } \\
\text { Saved }\end{array}$ & $\begin{array}{c}\text { Total } \\
\text { Saved }\end{array}$ & $\begin{array}{c}\text { Retrofit } \\
\text { Cost }(\$)\end{array}$ & $\begin{array}{c}\text { Payback } \\
\text { Period (yr) }\end{array}$ \\
\hline Minimal & 2,039 & 642 & 111 & 3,234 & 5,804 & 11,055 & 1.905 \\
Moderate & 3,713 & 1,169 & 203 & 10,505 & 15,184 & 11,498 & 0.757 \\
Advanced & 7,144 & 2,250 & 390 & 10,487 & 19,491 & 19,492 & 1.000 \\
\hline
\end{tabular}


All payback periods are short, whether or not maintenance is included. This result indicates the strong benefit of an energy-efficient retrofit in a heavily used installation like CMAS.

\subsection{SPACE CONDITIONING ENERGY SAVINGS}

All electrical power delivered to the lighting system eventually manifests itself as heat. Unless the system is specially designed to remove heat by means of ducts that allow air to flow through the fixtures and away from the room, this heat adds to the cooling load or reduces the heating requirement for the lighted space. In any case, the energy converted to light and transferred to the space affects the space conditioning requirement. A net energy savings results from the reduction in the electrical load for lighting, which is the product of the balance between the cooling energy benefit during chiller operation and the heating energy penalty during boiler operation.

\subsubsection{Cooling System Savings}

The energy savings estimate for the cooling system is based on the assumption that $1.25 \mathrm{~kW}$ of power is required per ton of air conditioning load. This figure has been recommended by ASHRAE for this type of calculation. Specific data for the CMAS system may differ. This area is open for further investigation.

\subsubsection{Heating System Penalty}

The heating system energy penalty is estimated on the basis of the assumption that the entire lighting load is converted to heat, so any reduction in lighting load directly increases heat demand. In fact, some heat from lighting fixtures is simply exhausted with purged air. In addition, a system efficiency of $85 \%$ is assumed. That is, $75 \%$ of the chemical potential energy in the fuel is converted to heat in the conditioned space. The balance is lost as flue gas sensible heat, combustion loss, duct loss, and piping heat loss. The 75\% figure may exceed actual system performance. The errors implicit in these simplifying assumptions offset each other.

\subsection{COST ANALYSIS}

\subsubsection{Cost Methodology}

The cost analysis is essentially a payback period analysis with enhancements to reflect the effect of a retrofit decision on lighting maintenance costs. A payback analysis is commonly used in 
lighting analysis because of its simplicity and because the concept of years required to cover initial investment is easily understood. The basic payback period is the ratio of initial investment to resulting annual energy savings. It does not account for differences in future investments that arise because of differences in equipment lifetimes and cost. It also does not account for the fact that existing equipment may be worn and will eventually be replaced. Finally, a payback value gives no indication of the total value of savings.

The basic payback approach has been enhanced by the addition of a maintenance savings calculation. Most energy lighting retrofits also result in reduced maintenance costs because the retrofit equipment has a longer expected life. Maintenance savings can be added to the energy savings so that payback is calculated on the basis of total savings.

As an example, consider the decision to retrofit an existing fluorescent fixture by only replacing the lamp. Without the retrofit, a cost for maintenance is incurred for routine bulb replacement. The expected bulb life of the standard 40-W T-12 lamp is $9,000 \mathrm{~h}$. Thus, about $97 \%$ $(8,760 / 9,000)$ of the existing bulbs would be replaced each year if they were used on a $24-\mathrm{h}$ basis. This calculation is based on the assumption that the existing bulbs are uniformly distributed by age (e.g., $5 \%$ of the bulbs are in the last $5 \%$ of their expected life at any time). The annual maintenance cost per existing lamp would therefore be $97 \%$ of the lamp replacement cost, including labor. For the retrofit 34-W T-12 lamp, the expected bulb life is $15,000 \mathrm{~h}$. Initially, the retrofit bulbs would not be uniformly distributed by age because they would be installed at the same time. However, after a few years of random replacement, the lamps would be distributed uniformly by age, and $58 \%$ of them $(8,760 / 15,000)$ would be replaced each year. Thus, the annual maintenance cost per existing lamp would be $58 \%$ of the lamp replacement cost. The actual maintenance cost in the first year is expected to be much lower because all the bulbs are new. This fact improves the payback calculation. However, the $58 \%$ figure has been used here because it is more representative of the long-term maintenance cost.

The maintenance savings is the difference between the maintenance cost for ongoing replacement of the existing lamps and the maintenance cost for ongoing replacement of the longerlived retrofit lamps; i.e., $97 \%$ of the existing lamp replacement minus $58 \%$ of the retrofit lamp replacement. This savings per lamp is multiplied by the number of lamps. A summary of the maintenance savings for each unit retrofit is provided in Table 8. The calculations have been performed as outlined above. Two additional assumptions are reflected in the calculations. First, maintenance is assumed to occur at the end of the year and has been discounted at $10 \%$ to the beginning of the year when retrofit occurs. Second, because of the long expected life of electronic ballasts, significant failure rates are not expected for many years, so zero maintenance costs are assumed. Certainly, ballast failures will not affect the payback calculation. 
TABLE 8 Maintenance Savings per Fixture

\begin{tabular}{|c|c|c|c|}
\hline Existing Component & Retrofit Scenario & Retrofit & $\begin{array}{l}\text { Maintenance } \\
\text { Savings (\$) }\end{array}$ \\
\hline \multirow[t]{3}{*}{$\mathrm{T}-12,40-\mathrm{W}, 1$-lamp fixture } & Minimal & $\begin{array}{l}\text { Replace lamps with } \mathrm{T}-12 \text {, } \\
34-\mathrm{W} \text { lamps }\end{array}$ & 3.50 \\
\hline & Moderate & $\begin{array}{l}\text { Replace with new T-8, } \\
32-W, 1 \text {-lamp fixture }\end{array}$ & 12.75 \\
\hline & Advanced & $\begin{array}{l}\text { Replace with new T-8, } \\
\text { 32-W, 1-lamp fixture }\end{array}$ & 12.75 \\
\hline \multirow[t]{3}{*}{ T-12, 40-W, 2-lamp fixture } & Minimal & $\begin{array}{l}\text { Replace lamps with } T-12 \text {, } \\
34-W \text { lamps }\end{array}$ & 7.00 \\
\hline & Moderate & $\begin{array}{l}\text { Rebuild fixture with two } \\
\mathrm{T}-8,32-\mathrm{W} \text { lamps and one } \\
\text { electronic ballast }\end{array}$ & 20.00 \\
\hline & Advanced & $\begin{array}{l}\text { Replace with new } \mathrm{T}-8 \text {, } \\
32-\mathrm{W} 1 \text {-lamp fixture and } \\
\text { electronic ballast }\end{array}$ & 22.60 \\
\hline \multirow[t]{3}{*}{$\mathrm{T}-12,40-\mathrm{W}, 3$-lamp fixture } & Minimal & $\begin{array}{l}\text { Replace lamps with } \mathrm{T}-12 \text {, } \\
34-\mathrm{W} \text { lamps }\end{array}$ & 10.50 \\
\hline & Moderate & $\begin{array}{l}\text { Rebuild fixture with three } \\
\mathrm{T}-8,32-\mathrm{W} \text { lamps and one } \\
\text { electronic ballast }\end{array}$ & 27.25 \\
\hline & Advanced & $\begin{array}{l}\text { Replace with new T-8, } \\
32-\mathrm{W}, 2 \text {-lamp fixture and } \\
\text { electronic ballasts }\end{array}$ & 29.90 \\
\hline \multirow[t]{3}{*}{$\mathrm{T}-12,40-\mathrm{W}, 4$-lamp fixture } & Minimal & $\begin{array}{l}\text { Replace lamps with T-12, } \\
34-W \text { lamps }\end{array}$ & 14.00 \\
\hline & Moderate & $\begin{array}{l}\text { Rebuild fixture with four } \\
\mathrm{T}-8,32-\mathrm{W} \text { lamps and one } \\
\text { electronic ballast }\end{array}$ & 34.50 \\
\hline & Advancèd & $\begin{array}{l}\text { Replace with new } T-8, \\
32-W, 2 \text {-lamp fixture and } \\
\text { electronic ballasts }\end{array}$ & 39.70 \\
\hline Magnetic ballast & Moderate $^{\mathrm{a}}$ & $\begin{array}{l}\text { Replace with electronic } \\
\text { ballasts }\end{array}$ & 5.50 \\
\hline Incandescent $<100 \mathrm{~W}$ & Moderate and advanced & $\begin{array}{l}\text { Replace with compact } \\
\text { fluorescent }\end{array}$ & 13.90 \\
\hline Incandescent $>100 \mathrm{~W}$ & Moderate and advanced & $\begin{array}{l}\text { Replace with 75-W, } \\
\text { PAR } 38\end{array}$ & 56.70 \\
\hline
\end{tabular}

a This maintenance savings is incorporated in the fixture rebuild and new fixture maintenance costs as listed above. It is isolated here for information only. 


\subsubsection{Existing Component Replacement Cost}

Table 9 lists the costs and component lifetimes assumed for estimating existing component maintenance costs. The costs for multiple lamp fixtures are simple multiples of the single-lamp cost. Replacements are assumed to occur on an as-needed basis only, so that only one lamp or ballast is replaced at a time. The cost figures for multiple-lamp fixtures are costs for maintaining those fixtures over time, not for the simultaneous replacement of all bulbs in the fixture.

\subsubsection{Retrofit Component Costs}

Table 10 lists the lifetimes of components used in the retrofit options. Table A.15 in Appendix A lists the equipment cost. The retrofit labor cost includes a $20 \%$ reduction as an economy of scale, since the retrofit involves the simultaneous replacement of multiple lighting components. The retrofit total cost is used to estimate the initial cost of a retrofit option. The maintenance total cost is used to estimate the maintenance savings as described in Section 6.5.1.

A single-lamp fixture is not included in the fixture rebuild options because it is cheaper to replace single-lamp fixtures than to rebuild them. Therefore, single-lamp fluorescent fixtures are replaced in the moderate retrofit option. Larger fixtures are rebuilt.

\subsubsection{Cost Calculations for Interior and Exterior Buildings}

Detailed cost tables in Appendix A list the energy (in kilowatt-hours) and dollar savings for each floor in each building. (The spreadsheets used to calculate the savings are provided on the CD-ROM version of this report.) Summary tables for each retrofit option are given in Tables 11-13. The summary tables focus only on the cost savings, retrofit costs, and payback period.

\subsection{SENSITIVITY ANALYSIS}

To examine the robustness of the results, a sensitivity analysis of the payback under different assumed electricity rates was conducted. The method used was to marginally alter the price of electricity in the spreadsheets and recalculate the costs, savings, and payback period. The results of numerous marginal changes are graphically presented in Figure 1. Additional sensitivity analysis can be implemented if further research is undertaken. 
TABLE 9 Costs for Existing Component Replacement

\begin{tabular}{cccccc}
\hline & & \multicolumn{5}{c}{ Cost $(\$)$} \\
\cline { 3 - 5 } Component & Life $(\mathrm{h})$ & Ballast & Lamp & Labor & Total \\
\hline & & & & & \\
T-12, 40-W fluorescent & & & & \\
1-lamp fixture & 9,000 & & 5.75 & 2.58 & 8.33 \\
2-lamp fixture & 9,000 & & 11.50 & 5.16 & 16.66 \\
3-lamp fixture & 9,000 & & 17.25 & 7.74 & 24.99 \\
4-lamp fixture & 9,000 & & 23.00 & 10.32 & 33.32 \\
& & & & & \\
Magnetic ballast & 90,000 & 22.50 & & 32.28 & 54.78 \\
& & & & & \\
Incandescent & & & & & \\
< 100W & 1,000 & & 1.50 & 2.58 & 4.08 \\
$>$ 100W & 750 & & 4.50 & 2.58 & 7.08 \\
\hline
\end{tabular}

TABLE 10 Retrofit Component Lifetimes

\begin{tabular}{lr}
\hline \multicolumn{1}{c}{ Component } & Life (h) \\
\hline T-12, 34-W, 1-lamp & 15,000 \\
T-8, 32-W, 1-lamp & 20,000 \\
T-8, 32-W, 2-lamp & 20,000 \\
T-8, 32-W, 3-lamp & 20,000 \\
T-8, 32-W, 4-lamp & 20,000 \\
T-8, 1×4, 1-lamp & 20,000 \\
T-8, 2×4, 2-lamp & 20,000 \\
Electronic ballast & 240,000 \\
Compact fluorescent light & 10,000 \\
75-W, PAR 38 floodlight & 2,500 \\
\hline
\end{tabular}


TABLE 11 Summary of Cost Analysis for Minimal Retrofit Option

\begin{tabular}{lrrrrrrr}
\hline \multicolumn{7}{c}{ Annual Amount $(\$)$} & \\
Bldg. & $\begin{array}{c}\text { Lighting } \\
\text { Saved }\end{array}$ & $\begin{array}{c}\text { Cooling } \\
\text { Saved }\end{array}$ & $\begin{array}{c}\text { Heating } \\
\text { Penalty }\end{array}$ & $\begin{array}{c}\text { Maintenance } \\
\text { Saved }\end{array}$ & $\begin{array}{c}\text { Total } \\
\text { Saved }\end{array}$ & $\begin{array}{r}\text { Retrofit } \\
\text { Cost }(\$)\end{array}$ & $\begin{array}{c}\text { Payback } \\
\text { Period (yr) }\end{array}$ \\
\cline { 2 - 5 } 1 & 1,656 & 521 & 90 & 2,625 & 4,712 & 9,177 & 1.95 \\
2 & 1,181 & 372 & 64 & 1,824 & 3,312 & 6,375 & 1.92 \\
3 & 2,216 & 698 & 121 & 3,514 & 6,307 & 12,285 & 1.95 \\
4 & 1,181 & 372 & 64 & 1,873 & 3,361 & 6,546 & 1.95 \\
5 & 581 & 183 & 32 & 921 & 1,652 & 3,218 & 1.95 \\
6 & 472 & 149 & 26 & 749 & 1,344 & 2,618 & 1.95 \\
7 & 494 & 156 & 27 & 784 & 1,407 & 2,741 & 1.95 \\
8 & 1,135 & 357 & 62 & 1,799 & 3,229 & 6,289 & 1.95 \\
9 & 1,475 & 464 & 80 & 2,338 & 4,197 & 8,173 & 1.95 \\
10 & 698 & 220 & 38 & 1,106 & 1,985 & 3,866 & 1.95 \\
11 & 1,455 & 458 & 79 & 2,307 & 4,140 & 8,063 & 1.95 \\
101 & 1,982 & 624 & 108 & 3,143 & 5,642 & 10,744 & 1.90 \\
617 & 57 & 18 & 3 & 91 & 163 & 311 & 1.90 \\
Total & 14,583 & 4,593 & 796 & 23,072 & 41,452 & 80,407 & 1.94 \\
\hline
\end{tabular}


TABLE 12 Summary of Cost Analysis for Intermediate Retrofit Option

\begin{tabular}{|c|c|c|c|c|c|c|c|}
\hline \multirow[b]{2}{*}{ Bldg. } & \multicolumn{5}{|c|}{ Annual Amount (\$) } & \multirow[b]{2}{*}{$\begin{array}{l}\text { Retrofit } \\
\text { Cost }(\$)\end{array}$} & \multirow[b]{2}{*}{$\begin{array}{c}\text { Payback } \\
\text { Period }(\mathrm{yr})\end{array}$} \\
\hline & $\begin{array}{l}\text { Lighting } \\
\text { Saved }\end{array}$ & $\begin{array}{c}\text { Cooling } \\
\text { Saved }\end{array}$ & $\begin{array}{l}\text { Heating } \\
\text { Penalty }\end{array}$ & $\begin{array}{l}\text { Maintenance } \\
\text { Saved }\end{array}$ & $\begin{array}{l}\text { Total } \\
\text { Saved }\end{array}$ & & \\
\hline 1 & 6,512 & 2,051 & 355 & 11,965 & 20,172 & 30,482 & 1.51 \\
\hline 2 & 5,038 & 1,587 & 275 & 9,640 & 15,990 & 16,797 & 1.05 \\
\hline 3 & 7,195 & 2,266 & 393 & 13,712 & 22,781 & 26,081 & 1.14 \\
\hline 4 & 4,224 & 1,330 & 230 & 8,091 & 13,415 & 20,265 & 1.51 \\
\hline 5 & 2,043 & 644 & 111 & 3,916 & 6,492 & 10,893 & 1.68 \\
\hline 6 & 1,347 & 424 & 73 & 2,630 & 4,328 & 7,620 & 1.76 \\
\hline 7 & 2,655 & 836 & 145 & 3,891 & 7,237 & 9,905 & 1.37 \\
\hline 8 & 2,985 & 940 & 163 & 6,075 & 9,837 & 16,656 & 1.69 \\
\hline 9 & 3,649 & 1,149 & 199 & 8,550 & 13,150 & 24,453 & 1.86 \\
\hline 10 & 2,218 & 698 & 121 & 4,163 & 6,959 & 10,178 & 1.46 \\
\hline 11 & 3,880 & 1,222 & 212 & 8,442 & 13,333 & 24,501 & 1.84 \\
\hline 101 & 3,554 & 1,119 & 194 & 10,075 & 14,554 & 11,167 & 0.77 \\
\hline 617 & 159 & 50 & 9 & 430 & 631 & 331 & 0.52 \\
\hline TotaI & 45,461 & 14,318 & 2,480 & 91,580 & 148,878 & 209,330 & 1.41 \\
\hline
\end{tabular}


TABLE 13 Summary of Cost Analysis for Advanced Retrofit Option

\begin{tabular}{|c|c|c|c|c|c|c|c|}
\hline \multirow[b]{2}{*}{ Bldg. } & \multicolumn{5}{|c|}{ Annual Amount (\$) } & \multirow[b]{2}{*}{$\begin{array}{l}\text { Retrofit } \\
\text { Cost }(\$)\end{array}$} & \multirow[b]{2}{*}{$\begin{array}{l}\text { Payback } \\
\text { Period (yr) }\end{array}$} \\
\hline & $\begin{array}{l}\text { Lighting } \\
\text { Saved }\end{array}$ & $\begin{array}{l}\text { Cooling } \\
\text { Saved }\end{array}$ & $\begin{array}{l}\text { Heating } \\
\text { Penalty }\end{array}$ & $\begin{array}{c}\text { Maintenance } \\
\text { Saved }\end{array}$ & $\begin{array}{l}\text { Total } \\
\text { Saved }\end{array}$ & & \\
\hline 1 & 10,324 & 3,251 & 563 & 12,641 & 25,654 & 33,743 & 1.42 \\
\hline 2 & 8,688 & 2,736 & 474 & 10,283 & 21,233 & 19,405 & 0.99 \\
\hline 3 & 14,466 & 4,556 & 789 & 14,996 & 33,228 & 34,284 & 1.15 \\
\hline 4 & 7,785 & 2,452 & 425 & 8,721 & 18,533 & 20,965 & 1.24 \\
\hline 5 & 3,751 & 1,181 & 205 & 4,218 & 8,945 & 10,951 & 1.35 \\
\hline 6 & 2,701 & 851 & 147 & 2,869 & 6,274 & 8,683 & 1.54 \\
\hline 7 & 4,127 & 1,300 & 225 & 4,151 & 9,352 & 9,767 & 1.12 \\
\hline 8 & 6,723 & 2,117 & 367 & 6,735 & 15,208 & 18,874 & 1.40 \\
\hline 9 & 8,344 & 2,628 & 455 & 9,380 & 19,897 & 25,248 & 1.42 \\
\hline 10 & 4,440 & 1,398 & 242 & 4,556 & 10,152 & 11,552 & 1.26 \\
\hline 11 & 8,089 & 2,548 & 441 & 9,189 & 19,385 & 26,392 & 1.53 \\
\hline 101 & 8,454 & 2,663 & 461 & 10,951 & 21,607 & 34,148 & 1.83 \\
\hline 617 & 351 & 110 & 19 & 464 & 906 & 982 & 1.21 \\
\hline Total & 88,242 & 27,791 & 4,814 & 99,154 & 210,374 & 254,995 & 1.34 \\
\hline
\end{tabular}




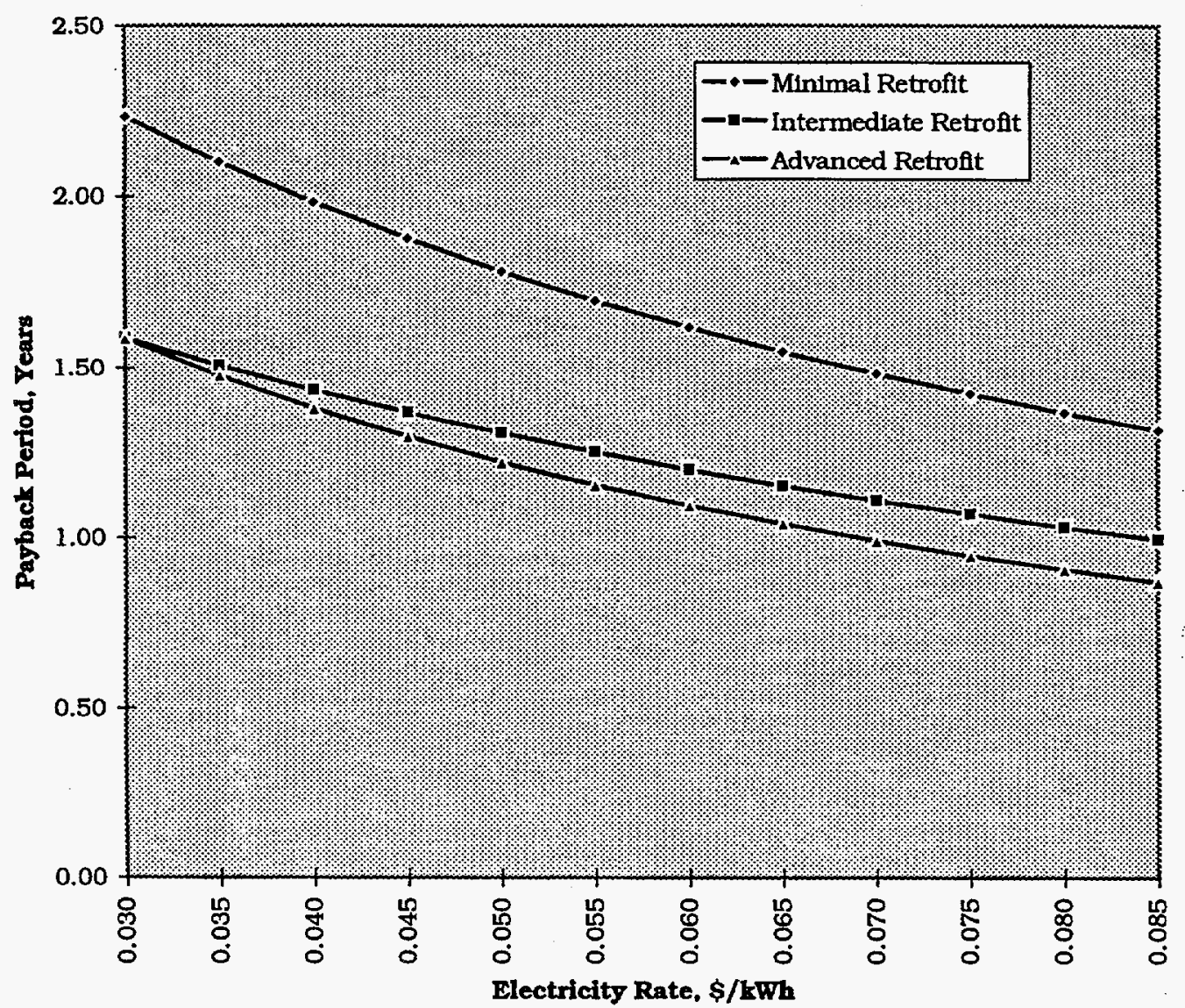

FIGURE 1 Sensitivity of Payback to Electricity Rate 


\section{RECOMMENDATIONS}

Since the payback periods for all three options are less than two years, it would seem that the best option would be the one that requires the least outlay of funds. However, this is not the case. As detailed in the cost analysis section of this report, other factors must be considered when selecting which lighting option to implement. For this reason, we recommend that CMAS pursue the advanced retrofit option.

The minimal retrofit option only takes advantage of lower-wattage lamps. It does not address light levels, light quality, or harmonics - all issues that affect the work space. By ignoring fluorescent ballasts, it postpones the inevitable disposal issue. The lamps used in this option do improve energy efficiency by reducing lumen output. (For a typical two-lamp system, lumen output is reduced by $18 \%$ to $20 \%$ ). However, unless these energy-saving (ES) lamps are installed only in areas that are currently overlit, their use might reduce light levels below recommended IES standards. Finally, there is no guarantee the estimated savings from this option would be fully realized; there is nothing to prevent the reinstallation of $40-\mathrm{W}$ lamps sometime in the future. For these reasons, we could not support the minimal retrofit option.

Of the two remaining retrofit options, the advanced retrofit would be the most cost-effective option because it would reduce the overall number of fixtures while maintaining or improving light levels as determined by IES standards. Implementation of this option would result in the best overall reduction in the use of energy for lighting and further reduce costs by reducing cooling requirements. Installing light control systems in selected areas should reduce overall energy use even more. Estimates of energy savings resulting from control systems were not factored into the energy use totals; energy use figures for the areas where controls might be used were based on a 24-h period of operation. The use of control systems in areas of infrequent use would decrease energy demand, since lights would be shut off when people are not present. The advanced retrofit option would also immediately reduce light maintenance costs, not only because most fixtures and lamps would be new but also because the expected life spans of the recommended light equipment are longer than those of the existing equipment. (For example, magnetic ballasts are rated for $90,000 \mathrm{~h}$ of operation; electronic ballasts, which run cooler, are estimated to run for $240,000 \mathrm{~h}$, more than two and one-half times longer.) This feature translates into a decrease in long-term maintenance costs. Finally, and most importantly, the lamps recommended in the advanced retrofit option can provide a better quality of light for the price. T-8 lamps provide a color rendering index (CRI) range of 70 to 85 , which compares favorably with natural daylight's CRI of 80 to 89 . For installations that never receive natural daylight, light quality is an important consideration. 
APPENDIX A:

DETAILED COST TABLES 
TABLE A.1 Overall Cost Savings from Using Retrofit Options at CMAS

Minimal Retrofit

\begin{tabular}{|c|c|c|c|c|c|c|c|c|c|c|c|c|c|c|}
\hline BLDG & $\begin{array}{c}\text { Currently } \\
\text { Installed } \\
\mathrm{KW}\end{array}$ & Retrofit kW & kW Savings & $\begin{array}{c}\text { Hours per } \\
\text { year }\end{array}$ & $\begin{array}{c}\text { Lighting kWh } \\
\text { Saved }\end{array}$ & $\begin{array}{l}\text { Cooling } \\
\text { MMBtu } \\
\text { Saved }\end{array}$ & $\begin{array}{l}\text { Heating } \\
\text { Penally } \\
\text { (MMBtu) }\end{array}$ & $\begin{array}{c}\text { Lighting \$ } \\
\text { Saved }\end{array}$ & $\begin{array}{l}\text { Cooling \$ } \\
\text { Saved }\end{array}$ & $\begin{array}{l}\text { Heating \$ } \\
\text { Penalty }\end{array}$ & $\begin{array}{c}\text { Maintenance \$ } \\
\text { Saved }\end{array}$ & Total \$ Saved & Retrofit Cost & $\begin{array}{c}\text { Payback } \\
\text { (years) }\end{array}$ \\
\hline 1 & 54.28 & 49.78 & 4.50 & 8,760 & 39,420 & 119.15 & 15.35 & $\$ 1,656$ & $\$ 521$ & $\$ 90$ & $\$ 2,625$ & $\$ 4,712$ & $\$ 9,177$ & 1.95 \\
\hline 2 & 41.34 & 38.13 & 3.21 & 8,760 & 28,120 & 84.99 & 10.95 & $\$ 1,181$ & $\$ 372$ & $\$ 64$ & $\$ 1,824$ & $\$ 3,312$ & $\$ 6,375$ & 1.92 \\
\hline 3 & 66.39 & 60.37 & 6.02 & 8,760 & 52.770 & 159.50 & 20.55 & $\$ 2,216$ & $\$ 698$ & $\$ 121$ & $\$ 3,514$ & $\$ 6,307$ & $\$ 12,285$ & 1.95 \\
\hline 4 & 37.08 & 33.87 & 3.21 & 8,760 & 28,120 & 84.99 & 10.95 & $\$ 1,181$ & $\$ 372$ & $\$ 64$ & $\$ 1,873$ & $\$ 3,361$ & $\$ 6,546$ & 1.95 \\
\hline 5 & 18.07 & 16.50 & 1.58 & 8,760 & 13,823 & 41.78 & 5.38 & $\$ 581$ & $\$ 183$ & $\$ 32$ & . $\$ 921$ & $\$ 1,652$ & $\$ 3,218$ & 1.95 \\
\hline 6 & 13.18 & 11.90 & 1.28 & 8,760 & 11.248 & 34.00 & 4.38 & $\$ 472$ & $\$ 149$ & $\$ 26$ & $\$ 749$ & $\$ 1,344$ & $\$ 2,618$ & 1.95 \\
\hline 7 & 19.02 & 17.68 & 1.34 & 8,760 & 11.773 & 35.59 & 4.59 & $\$ 494$ & $\$ 156$ & $\$ 27$ & $\$ 784$ & $\$ 1,407$ & $\$ 2,741$ & 1.95 \\
\hline 8 & 30.63 & 27.55 & 3.08 & 8,760 & 27.016 & 81.66 & 10.52 & $\$ 1.135$ & $\$ 357$ & $\$ 62$ & $\$ 1.799$ & $\$ 3,229$ & $\$ 6,289$ & 1.95 \\
\hline 9 & 39.41 & 35.41 & 4.01 & 8,760 & 35,110 & 106.12 & 13.68 & $\$ 1,475$ & $\$ 464$ & $\$ 80$ & $\$ 2,338$ & $\$ 4,197$ & $\$ 8,173$ & 1.95 \\
\hline 10 & 21,14 & 19.24 & 1.90 & 8,760 & 16,609 & 50.20 & 6.47 & $\$ 698$ & $\$ 220$ & $\$ 38$ & $\$ 1,106$ & $\$ 1,985$ & $\$ 3,866$ & 1.95 \\
\hline 11 & 39.84 & 35,89 & 3.95 & 8.760 & 34,637 & 104.69 & 13.49 & $\$ 1,455$ & $\$ 458$ & $\$ 79$ & $\$ 2,307$ & $\$ 4,140$ & $\$ 8,063$ & 1.95 \\
\hline 101 & 48.08 & 42.69 & 5.39 & 8,760 & 47,199 & 142.66 & 18.38 & $\$ 1,982$ & $\$ 624$ & $\$ 108$ & $\$ 3,143$ & $\$ 5,642$ & $\$ 10,744$ & 1.90 \\
\hline 617 & 6.50 & 6.34 & 0.16 & 8,760 & 1.367 & 4.13 & 0.53 & $\$ 57$ & $\$ 18$ & $\$ 3$ & $\$ 91$ & $\$ 163$ & $\$ 311$ & 1.90 \\
\hline TOTALS & 434.98 & 395.34 & 34.09 & 8,760 & 298,646 & $1,049.45$ & 135.24 & $\$ 14,583$ & $\$ 4,593$ & $\$ 796$ & $\$ 23,072$ & $\$ 41,452$ & $\$ 80,407$ & 1.94 \\
\hline
\end{tabular}

Infermediate Retrofit

\begin{tabular}{|c|c|c|c|c|c|c|c|c|c|c|c|c|c|c|}
\hline BLDG & $\begin{array}{c}\text { Currently } \\
\text { Installed } \\
\mathrm{kW}\end{array}$ & Retrofit $\mathrm{kW}$ & kW Savings & $\begin{array}{c}\text { Hours per } \\
\text { year }\end{array}$ & $\begin{array}{c}\text { Lighting kWh } \\
\text { Saved }\end{array}$ & $\begin{array}{l}\text { Cooling } \\
\text { MMBtu } \\
\text { Saved }\end{array}$ & $\begin{array}{c}\text { Heating } \\
\text { Penalty } \\
\text { (MMBtu) }\end{array}$ & $\begin{array}{l}\text { Lighting \$ } \\
\text { Saved }\end{array}$ & $\begin{array}{l}\text { Cooling \$ } \\
\text { Saved }\end{array}$ & $\begin{array}{l}\text { Healing \$ } \\
\text { Penalty }\end{array}$ & $\begin{array}{c}\text { Maintenance } \$ \\
\text { Saved }\end{array}$ & Total \$ Saved & Retrofit Cost & $\begin{array}{c}\text { Payback } \\
\text { (years) }\end{array}$ \\
\hline 1 & 54.28 & 36.58 & 17.70 & 8,760 & 155,052 & 468.65 & 60.39 & $\$ 6,512$ & $\$ 2,051$ & $\$ 355$ & $\$ 11,965$ & $\$ 20,172$ & $\$ 30,482$ & 1.51 \\
\hline 2 & 41.34 & 27.65 & 13.69 & 8,760 & 119,951 & 362.55 & 46.72 & $\$ 5,038$ & $\$ 1,587$ & $\$ 275$ & $\$ 9,640$ & $\$ 15,990$ & $\$ 16,797$ & 1.05 \\
\hline 3 & 66.39 & 46.84 & 19.56 & B,760 & 171,319 & 517.81 & 66.73 & $\$ 7,195$ & $\$ 2,266$ & $\$ 393$ & $\$ 13,712$ & $\$ 22,781$ & $\$ 26,081$ & 1.14 \\
\hline 4 & 37.08 & 25.60 & 11.48 & 8,760 & 100,565 & 303.96 & 39.17 & $\$ 4,224$ & $\$ 1,330$ & $\$ 230$ & $\$ 8,091$ & $\$ 13,415$ & $\$ 20,265$ & 1.51 \\
\hline 5 & 18.07 & 12.52 & 5.55 & 8,760 & 48,653 & 147.05 & 18.95 & $\$ 2,043$ & $\$ 644$ & $\$ 111$ & $\$ 3,916$ & $\$ 6,492$ & $\$ 10,893$ & 1.68 \\
\hline 6 & 13.18 & 9.52 & 3.66 & 8,760 & 32,079 & 96.96 & 12.49 & $\$ 1 ; 347$ & $\$ 424$ & $\$ 73$ & $\$ 2,630$ & $\$ 4,328$ & $\$ 7.620$ & 1.76 \\
\hline 7 & 19.02 & 11.81 & 7.22 & 8,760 & 63,221 & 191.09 & 24.62 & $\$ 2,655$ & $\$ 836$ & $\$ 145$ & $\$ 3,891$ & $\$ 7,237$ & $\$ 9,905$ & 1.37 \\
\hline 8 & 30.63 & 22.52 & 8.11 & 8,760 & 71,061 & 214.78 & 27.68 & $\$ 2,985$ & $\$ 940$ & $\$ 163$ & $\$ 6,075$ & $\$ 9,837$ & $\$ 16,656$ & 1.69 \\
\hline 9 & 39.41 & 29.50 & 9.92 & 8,760 & 86,890 & 262.63 & 33.84 & $\$ 3,649$ & $\$ 1,149$ & $\$ 199$ & $\$ 8,550$ & $\$ 13,150$ & $\$ 24,453$ & 1.86 \\
\hline 10 & 21.14 & 15.11 & 6.03 & 8,760 & 52,805 & 159.60 & 20.57 & $\$ 2,218$ & $\$ 698$ & $\$ 121$ & $\$ 4,163$ & $\$ 6,959$ & $\$ 10,178$ & 1.46 \\
\hline 11 & 39.84 & 29.30 & 10.55 & 8,760 & 92,392 & 279.25 & 35.99 & $\$ 3,880$ & $\$ 1,222$ & $\$ 212$ & $\$ 8,442$ & $\$ 13,333$ & $\$ 24,501$ & 1.84 \\
\hline 101 & 48.08 & 38.42 & 9.66 & 8,760 & 84,613 & 255.74 & 32.96 & $\$ 3,554$ & $\$ 1,119$ & $\$ 194$ & $\$ 10,075$ & $\$ 14,554$ & $\$ 11.167$ & 0.77 \\
\hline 617 & 6.50 & 6.07 & 0.43 & 8,760 & 3,793 & 11.46 & 1.48 & $\$ 159$ & $\$ 50$ & $\$ 9$ & $\$ 430$ & $\$ 631$ & $\$ 331$ & 0.52 \\
\hline TOTALS & 434.98 & 311.41 & 113.47 & 8.760 & 993,988 & $3,271.54$ & 421.59 & $\$ 45,461$ & $\$ 14,318$ & $\$ 2,480$ & $\$ 91,580$ & $\$ 148,878$ & $\$ 209,330$ & 1.41 \\
\hline
\end{tabular}


TABLE A.1 (Cont.)

\section{Advanced Retrofit}

\begin{tabular}{|c|c|c|c|c|c|c|c|c|c|c|c|c|c|c|}
\hline BLDG & $\begin{array}{c}\text { Currently } \\
\text { installod } \\
\mathrm{kW}\end{array}$ & Retrofit $\mathrm{kW}$ & kW Savings & $\begin{array}{c}\text { Hours per } \\
\text { year }\end{array}$ & $\begin{array}{c}\text { Lighting kWh } \\
\text { Savod }\end{array}$ & $\begin{array}{l}\text { Cooling } \\
\text { MMBtu } \\
\text { Savod }\end{array}$ & $\begin{array}{c}\text { Heating } \\
\text { Penalty } \\
\text { (MMBtu) }\end{array}$ & $\begin{array}{l}\text { Lighting \$ } \\
\text { Saved }\end{array}$ & $\begin{array}{c}\text { Cooling } \$ \\
\text { Saved }\end{array}$ & $\begin{array}{l}\text { Healing \$ } \\
\text { Penalty }\end{array}$ & $\begin{array}{c}\text { Maintenance } \$ \\
\text { Saved }\end{array}$ & Total \$ Saved & Retrofit Cost & $\begin{array}{c}\text { Payback } \\
\text { (yoars) }\end{array}$ \\
\hline 1 & 54.28 & 29.17 & 25.12 & 8,760 & 220,007 & 664.97 & 85.69 & $\$ 9,240$ & $\$ 2,910$ & $\$ 504$ & $\$ 12,035$ & $\$ 23,681$ & $\$ 33,743$ & 1.42 \\
\hline 2 & 41.34 & 20.21 & 21.13 & 8,760 & 185,081 & 559.41 & 72.09 & $\$ 7,773$ & $\$ 2,448$ & $\$ 424$ & $\$ 9,783$ & $\$ 19,581$ & $\$ 19,405$ & 0.99 \\
\hline 3 & 66.39 & 32.05 & 34.34 & B.760 & 300,836 & 909.28 & 117.17 & $\$ 12,635$ & $\$ 3,979$ & $\$ 689$ & $\$ 13,961$ & $\$ 29,886$ & $\$ 34,284$ & 1.15 \\
\hline 4 & 37.08 & 18.37 & 18.71 & 8.760 & 163.900 & 495.39 & 63.84 & $\$ 6,884$ & $\$ 2,168$ & $\$ 376$ & $\$ 8,221$ & $\$ 16,897$ & $\$ 20,965$ & 1.24 \\
\hline 5 & 18.07 & 9.09 & 8.99 & 8.760 & 78,744 & 238.00 & 30.67 & $\$ 3,307$ & $\$ 1,042$ & $\$ 180$ & $\$ 3,968$ & $\$ 8,137$ & $\$ 10,951$ & 1.35 \\
\hline 6 & 13.18 & 6.76 & 6.42 & 8,760 & 56,257 & 170.04 & 21.91 & $\$ 2,363$ & $\$ 744$ & $\$ 129$ & $\$ 2,670$ & $\$ 5,648$ & $\$ 8,683$ & 1.54 \\
\hline 7 & 19.02 & 8.81 & 10.22 & 8,760 & 89,501 & 270.52 & 34.86 & $\$ 3,759$ & $\$ 1,184$ & $\$ 205$ & $\$ 3,947$ & $\$ 8,685$ & $\$ 9,767$ & 1.12 \\
\hline 8 & 30.63 & 14.90 & 15.73 & 8,760 & 137.812 & 416.54 & 53.68 & $\$ 5,788$ & $\$ 1,823$ & $\$ 316$ & $\$ 6,210$ & $\$ 13,505$ & $\$ 18,874$ & 1.40 \\
\hline 9 & 39.41 & 19.93 & 19.49 & 8,760 & 170,724 & 516.01 & 66.50 & $\$ 7.170$ & $\$ 2,258$ & $\$ 391$ & $\$ 8.727$ & $\$ 17.765$ & $\$ 25,248$ & 1.42 \\
\hline 10 & 21.14 & 10.58 & 10.56 & 8,760 & 92,488 & 279.55 & 36.02 & $\$ 3,884$ & $\$ 1,223$ & $\$ 212$ & $\$ 4,250$ & $\$ 9,146$ & $\$ 11,552$ & 1.26 \\
\hline 11 & 39.84 & 21.04 & 18.81 & 8.760 & 164,749 & 497.96 & 64.17 & $\$ 6,919$ & $\$ 2,179$ & $\$ 377$ & $\$ 8,521$ & $\$ 17,242$ & $\$ 26,392$ & 1.53 \\
\hline 101 & 48.08 & 29.49 & 18.59 & 8.760 & 162,883 & 492.32 & 63.44 & $\$ 6,841$ & $\$ 2,155$ & $\$ 373$ & $\$ 10,054$ & $\$ 18,677$ & $\$ 34,148$ & 1.83 \\
\hline 617 & 6.50 & 5.68 & 0.82 & 8,760 & 7,209 & 21.79 & 2.81 & $\$ 303$ & $\$ 95$ & $\$ 17$ & $\$ 433$ & $\$ 815$ & $\$ 982$ & 1.21 \\
\hline OTALS & 434.98 & 226.05 & 189.51 & 8,760 & $1,660,099$ & $5,531.76$ & 712.86 & $\$ 76,868$ & $\$ 24,209$ & $\$ 4,193$ & $\$ 92,782$ & $\$ 189,666$ & $\$ 254,995$ & 1.34 \\
\hline
\end{tabular}


TABLE A.2 Cost Savings from Using Retrofit Options at Building 1

\begin{tabular}{|c|c|c|c|c|c|c|c|c|c|c|c|c|c|c|c|}
\hline BLDG & Floor & $\begin{array}{c}\text { Currently } \\
\text { Installod } \\
\mathrm{kW}\end{array}$ & Retrofit $\mathrm{kW}$ & $\begin{array}{c}\mathrm{kW} \\
\text { Savings }\end{array}$ & $\begin{array}{c}\text { Hours } \\
\text { peryear }\end{array}$ & $\begin{array}{c}\text { Lighting } \\
\text { kWh Savod }\end{array}$ & $\begin{array}{l}\text { Cooling } \\
\text { MMBtu } \\
\text { Saved }\end{array}$ & $\begin{array}{c}\text { Heating } \\
\text { Penalty } \\
\text { (MMBtu) }\end{array}$ & $\begin{array}{l}\text { Lighting \$ } \\
\text { Saved }\end{array}$ & $\begin{array}{c}\text { Cooling } \$ \\
\text { Saved }\end{array}$ & $\begin{array}{l}\text { Heating } \$ \\
\text { Penalty }\end{array}$ & $\begin{array}{c}\text { Maintenance } \\
\text { \$ Saved }\end{array}$ & $\begin{array}{l}\text { Total \$ } \\
\text { Saved }\end{array}$ & Retrofit Costs & $\begin{array}{l}\text { Payback } \\
\text { (years) }\end{array}$ \\
\hline 1 & FIRST FLOOA & 11.55 & 10.33 & 1.22 & 8,760 & 10,722 & 32.41 & 4.18 & $\$ 450$ & $\$ 142$ & $\$ 25$ & $\$ 714$ & $\$ 1,282$ & $\$ 2,496$ & 1.95 \\
\hline 1 & SECOND FLOOA & 20.89 & 18.68 & 2.20 & 8,760 & 19,290 & 58.30 & 7.51 & $\$ 810$ & $\$ 255$ & $\$ 44$ & $\$ 1,285$ & $\$ 2,306$ & $\$ 4,491$. & 1.95 \\
\hline 1 & THIRD FLOOR & 21.84 & 20.77 & 1.07 & 8,760 & 9,408 & 28.44 & 3.66 & $\$ 395$ & $\$ 124$ & $\$ 22$ & $\$ 627$ & $\$ 1.125$ & $\$ 2,190$ & 1.95 \\
\hline TOTAL & & 54.28 & 49,78 & 4.50 & 8,760 & 39,420 & 119.15 & 15.35 & $\$ 1,656$ & $\$ 521$ & $\$ 90$ & $\$ 2,625$ & $\$ 4,712$ & $\$ 9,177$ & .95 \\
\hline
\end{tabular}

Intrermedlate Retrofit

\begin{tabular}{|c|c|c|c|c|c|c|c|c|c|c|c|c|c|c|c|}
\hline BLDG & Floor & $\begin{array}{c}\text { Currently } \\
\text { Installed } \\
\mathrm{kW}\end{array}$ & Retrofit kW & $\begin{array}{c}k W \\
\text { Savings }\end{array}$ & $\begin{array}{c}\text { Hours } \\
\text { per year }\end{array}$ & $\begin{array}{c}\text { Lighting } \\
\text { kWh Saved }\end{array}$ & $\begin{array}{l}\text { Cooling } \\
\text { MMBtu } \\
\text { Saved }\end{array}$ & $\begin{array}{c}\text { Heatung } \\
\text { Penalty } \\
\text { (MMB(U) }\end{array}$ & $\begin{array}{l}\text { Lighting \$ } \\
\text { Saved }\end{array}$ & $\begin{array}{l}\text { Cooling S } \\
\text { Saved }\end{array}$ & $\begin{array}{c}\text { Heating \$ } \\
\text { Penalty }\end{array}$ & $\begin{array}{c}\text { Maintenance } \\
\text { \$ Saved }\end{array}$ & $\begin{array}{l}\text { Totals } \\
\text { Saved } \\
\end{array}$ & Retrofit Costs & $\begin{array}{l}\text { Payback } \\
\text { (years) }\end{array}$ \\
\hline 1 & FIRST FLOOR & 11.55 & 9.05 & 2.51 & 8.760 & 21,961 & 66.38 & 8.55 & $\$ 922$ & $\$ 290$ & $\$ 50$ & $\$ 2,537$ & $\$ 3,700$ & $\$ 6,351$ & 1.72 \\
\hline 1 & SECOND FLOOR & 20.89 & 15.93 & 4.96 & 8,760 & 43,458 & 131.35 & 16.93 & $\$ 1,825$ & $\$ 575$ & $\$ 100$ & $\$ 4,387$ & $\$ 6,688$ & $\$ 12,624$ & 1.89 \\
\hline 1 & THIRD FLOOR & 21.84 & 11.61 & 10.23 & 8,760 & 89,632 & 270.91 & 34.91 & $\$ 3,765$ & $\$ 1,186$ & $\$ 205$ & $\$ 5,040$ & $\$ 9,785$ & $\$ 11,507$ & 1.18 \\
\hline
\end{tabular}

Advanced Retrofit

\begin{tabular}{|c|c|c|c|c|c|c|c|c|c|c|c|c|c|c|c|}
\hline BLDG & Floor & $\begin{array}{c}\text { Currently } \\
\text { Installed } \\
\mathrm{kW}\end{array}$ & Retrofit kW & $\begin{array}{c}\text { kW } \\
\text { Savings }\end{array}$ & $\begin{array}{c}\text { Hours } \\
\text { per year }\end{array}$ & $\begin{array}{l}\text { Lighting } \\
\text { kWh Saved }\end{array}$ & $\begin{array}{l}\text { Cooling } \\
\text { MMBtu } \\
\text { Saved }\end{array}$ & $\begin{array}{c}\text { Heating } \\
\text { Penalty } \\
\text { (MMBtu) }\end{array}$ & $\begin{array}{l}\text { Lighting } \$ \\
\text { Saved }\end{array}$ & $\begin{array}{c}\text { Cooling } \$ \\
\text { Saved }\end{array}$ & $\begin{array}{l}\text { Heating \$ } \\
\text { Penalty }\end{array}$ & $\begin{array}{c}\text { Maintenance } \\
\text { \$ Saved }\end{array}$ & $\begin{array}{l}\text { Total \$ } \\
\text { Saved }\end{array}$ & Retrofit Costs & $\begin{array}{l}\text { Payback } \\
\text { (years) }\end{array}$ \\
\hline 1 & FIRST FLOOR & 11.55 & 6.18 & 5.37 & 8,760 & 47,059 & 142.24 & 18.33 & $\$ 1,976$ & $\$ 622$ & $\$ 108$ & $\$ 2,588$ & $\$ 5,079$ & $\$ 7,344$ & 1.45 \\
\hline 1 & SECOND FLOOR & 20.89 & 12.16 & 8.73 & 8,760 & 76,484 & 231.17 & 29.79 & $\$ 3,212$ & $\$ 1,012$ & $\$ 175$ & $\$ 4,390$ & $\$ 8,439$ & $\$ 15,017$ & 1.78 \\
\hline 1 & THIRD FLOOR & 21.84 & 10.83 & 11.01 & 8,760 & 96,465 & 291.57 & 37.57 & $\$ 4,052$ & $\$ 1,276$ & $\$ 221$ & $\$ 5,057$ & $\$ 10,163$ & $\$ 11,381$ & 1.12 \\
\hline TOTALS & & 54.28 & 29.17 & 25.12 & 8,760 & 220,007 & 664.97 & 85.69 & $\$ 9,240$ & $\$ 2,910$ & $\$ 504$ & $\$ 12,035$ & $\$ 23,681$ & $\$ 33,743$ & 1.42 \\
\hline
\end{tabular}


TABLE A.3 Cost Savings from Using Retrofit Options at Building 2

\begin{tabular}{|c|c|c|c|c|c|c|c|c|c|c|c|c|c|c|c|}
\hline BLDG & Floor & \begin{tabular}{|c|} 
Currently \\
Installed \\
$\mathrm{KW}$
\end{tabular} & Retrofit KW & $\begin{array}{c}\mathrm{KW} \\
\text { Savings }\end{array}$ & $\begin{array}{c}\text { Hours } \\
\text { per year }\end{array}$ & $\begin{array}{c}\text { Lighting } \\
\text { KWH Savod }\end{array}$ & $\begin{array}{l}\text { Cooling } \\
\text { MMBtu } \\
\text { Saved }\end{array}$ & $\begin{array}{l}\text { Heating } \\
\text { Penalty } \\
\text { (MMBtu) }\end{array}$ & $\begin{array}{l}\text { Lighting } \$ \\
\text { Saved }\end{array}$ & $\begin{array}{c}\text { Cooling } \$ \\
\text { Saved }\end{array}$ & $\begin{array}{l}\text { Heating S } \\
\text { Penatty }\end{array}$ & $\begin{array}{l}\text { Maintenance } \\
\text { \$S Saved }\end{array}$ & $\begin{array}{l}\text { Total \$ } \\
\text { Saved }\end{array}$ & $\begin{array}{l}\text { Retrofit } \\
\text { Costs }\end{array}$ & $\begin{array}{l}\text { Payback } \\
\text { (years) }\end{array}$ \\
\hline 2 & FIRST FLOOA & 25.92 & 23.80 & 2.124 & 8,760 & 18,606 & 56.24 & 7.25 & $\$ 781$ & $\$ 246$ & $\$ 43$ & $\$ 1,239$ & $\$ 2,22$ & $\$ 4,331$ & 1.95 \\
\hline 2 & SECOND FLOOR & 6.40 & 5.83 & 0.576 & 8,760 & 5,046 & 15.25 & 1.97 & $\$ 212$ & $\$ 67$ & $\$ 12$ & $\$ 336$ & $\$ 60$ & $\$ 1,175$ & 1.95 \\
\hline 2 & THIRD FLOOR & 9.02 & 8.51 & 0.51 & 8.760 & 4,468 & 13.50 & 1.74 & $\$ 188$ & $\$ 59$ & $\$ 10$ & $\$ 249$ & $\$ 489$ & $\$ 869$ & 1.79 \\
\hline
\end{tabular}

\begin{tabular}{|c|c|c|c|c|c|c|c|c|c|c|c|c|c|c|c|}
\hline BLDG & Floor & $\begin{array}{c}\text { Currently } \\
\text { Installed } \\
\mathrm{KW}\end{array}$ & Retrofit KW & $\begin{array}{c}\mathrm{KW} \\
\text { Savings }\end{array}$ & $\begin{array}{c}\text { Hours } \\
\text { per year }\end{array}$ & $\begin{array}{c}\text { Lighting } \\
\text { KWH Saved }\end{array}$ & $\begin{array}{l}\text { Cooling } \\
\text { MMBtu } \\
\text { Saved }\end{array}$ & $\begin{array}{c}\text { Heating } \\
\text { Penalty } \\
\text { (MMBtu) }\end{array}$ & $\begin{array}{l}\text { Lighting } \$ \\
\text { Saved }\end{array}$ & $\begin{array}{l}\text { Cooling \$ } \\
\text { Saved }\end{array}$ & $\begin{array}{l}\text { Heating } \$ \\
\text { Penalty }\end{array}$ & $\begin{array}{c}\text { Maintenance \$ } \\
\text { Saved }\end{array}$ & Total \$ Saved & $\begin{array}{l}\text { Retrofit } \\
\text { Costs }\end{array}$ & $\begin{array}{l}\text { Payback } \\
\text { (years) }\end{array}$ \\
\hline $\begin{array}{l}2 \\
2\end{array}$ & $\begin{array}{l}\text { FIRST FLOOR } \\
\text { SECOND FLOOR }\end{array}$ & $\begin{array}{r}25.92 \\
6.40\end{array}$ & $\begin{array}{r}17.62 \\
4.43\end{array}$ & $\begin{array}{l}8.307 \\
1.968\end{array}$ & $\begin{array}{l}8,760 \\
8,760\end{array}$ & $\begin{array}{l}72,769 \\
17,240\end{array}$ & $\begin{array}{r}219.95 \\
52.11\end{array}$ & $\begin{array}{r}28.34 \\
6.71\end{array}$ & $\$ 3,056$ & $\begin{array}{l}\$ 963 \\
\$ 228\end{array}$ & $\begin{array}{r}\$ 167 \\
\$ 39\end{array}$ & $\$ 5,700$ & $\begin{array}{l}\$ 9,552 \\
\$ 2,108 \\
\$ 4,329\end{array}$ & $\begin{array}{l}\$ 9,690 \\
\$ 3,994 \\
\$ 113\end{array}$ & $\begin{array}{l}1.01 \\
1.89 \\
072\end{array}$ \\
\hline 2 & THIRD FLOOR & 9.02 & 5.60 & 3.418 & 8,760 & 29,942 & 90.50 & $\frac{11.66}{46.72}$ & 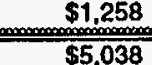 & $\begin{array}{l}\$ 396 \\
\$ 1,587\end{array}$ & $\begin{array}{l}\$ 69 \\
\$ 275\end{array}$ & $\$$ & 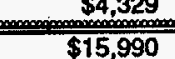 & \$16,797 & 1.05 \\
\hline
\end{tabular}

\begin{tabular}{|c|c|c|c|c|c|c|c|c|c|c|c|c|c|c|c|}
\hline BLDG & Floor & $\begin{array}{c}\text { Currently } \\
\text { Installed } \\
\mathrm{KW}\end{array}$ & Retrofit KW & $\begin{array}{c}\mathrm{KW} \\
\text { Savings }\end{array}$ & $\begin{array}{c}\text { Hours } \\
\text { per year }\end{array}$ & $\begin{array}{c}\text { Lighting } \\
\text { KWH Saved }\end{array}$ & $\begin{array}{l}\text { Cooling } \\
\text { MMBtu } \\
\text { Saved }\end{array}$ & $\begin{array}{l}\text { Heating } \\
\text { Penalty } \\
\text { (MMBlu) }\end{array}$ & $\begin{array}{l}\text { Lighting \$ } \\
\text { Savod }\end{array}$ & $\begin{array}{l}\text { Cooling \$ } \\
\text { Saved }\end{array}$ & $\begin{array}{l}\text { Heating } \$ \\
\text { Penalty }\end{array}$ & $\begin{array}{c}\text { Maintenance } \$ \\
\text { Saved }\end{array}$ & Total \$ Saved & $\begin{array}{l}\text { Retrofit } \\
\text { Costs }\end{array}$ & $\begin{array}{l}\text { Payback } \\
\text { (years) }\end{array}$ \\
\hline 2 & FIRST FLOOR & 25.92 & 12.59 & 13.337 & 8,760 & 116,832 & 353.13 & 45.51 & . $\$ 4,907$ & $\$ 1,545$ & $\$ 268$ & $\$ 5,801$ & $\$ 11,986$ & $\$ 12,500$ & 1.04 \\
\hline 2 & SECOND FLOOR & 6.40 & 3.09 & 3.313 & 8.760 & 29,022 & 87.72 & 11.30 & $\$ 1,219$ & $\$ 384$ & $\$ 66$ & $\$ 1,226$ & $\$ 2,762$ & $\$ 3,830$ & 1.39 \\
\hline 2 & THIRD FLOOR & 9.02 & 4.54 & 4.478 & 8.760 & 39,227 & 118.56 & 15.28 & $\$ 1,648$ & $\$ 519$ & $\$ 90$ & $\$ 2,756$ & $\$ 4,833$ & $\$ 3,075$ & 0.64 \\
\hline OTALS & & 41.34 & 20.21 & 21.128 & 8,760 & 185,081 & 559.41 & 72.09 & $\$ 7.773$ & $\$ 2,448$ & $\$ 424$ & $\$ 9,783$ & $\$ 19,581$ & $\$ 19,405$ & 0.99 \\
\hline
\end{tabular}


TABLE A.4 Cost Savings from Using Retrofit Options at Building 3

\begin{tabular}{|c|c|c|c|c|c|c|c|c|c|c|c|c|c|c|c|}
\hline BLDG & Floor & $\begin{array}{c}\text { Installed } \\
\mathrm{KW}\end{array}$ & Retrofit KW & $\begin{array}{c}\mathrm{KW} \\
\text { Savings }\end{array}$ & $\begin{array}{c}\text { Hours } \\
\text { per year }\end{array}$ & $\begin{array}{c}\text { Lighting } \\
\text { KWH Saved }\end{array}$ & $\begin{array}{l}\text { MMBtu } \\
\text { Saved }\end{array}$ & $\begin{array}{l}\text { Penalty } \\
\text { (MMBtu) }\end{array}$ & $\begin{array}{l}\text { Lighting } \$ \\
\text { Saved }\end{array}$ & $\begin{array}{l}\text { Cooling \$ } \\
\text { Saved }\end{array}$ & $\begin{array}{l}\text { Heating s } \\
\text { Penalty }\end{array}$ & $\begin{array}{l}\text { Maintenance } \\
\text { \$ Saved }\end{array}$ & $\begin{array}{l}\text { Total \$ } \\
\text { Saved }\end{array}$ & Retrofit Costs & $\begin{array}{l}\text { Payback } \\
\text { (years) }\end{array}$ \\
\hline 3 & FIRSTFLOOR & 9.76 & 8.91 & 0.86 & 8,760 & 7.516 & 22.72 & 2.93 & $\$ 316$ & $\$ 99$ & $\$ 17$ & $\$ 501$ & $\$ 898$ & $\$ 1,750$ & 1.95 \\
\hline 3 & SECOND FLOOR & 9.60 & 8.69 & 0.91 & 8,760 & 7,937 & 23.99 & 3.09 & $\$ 333$ & $\$ 105$ & $\$ 18$ & $\$ 529$ & $\$ 949$ & $\$ 1,848$ & 1.95 \\
\hline 3 & THIRD FLOOR & 39.53 & 35.27 & 4.26 & $B, 760$ & 37,318 & 112.79 & 14.54 & $\$ 1,567$ & $\$ 494$ & $\$ 86$ & $\$ 2,485$ & $\$ 4,460$ & $\$ 8,687$ & 1.95 \\
\hline 3 & $\mathrm{AB} / \mathrm{BB}$ & 7.50 & 7.50 & 0.00 & 8,760 & 0 & 0.00 & 0.00 & so & $\$ 0$ & $\$ 0$ & so & so & so & \\
\hline OTALS & & 66.39 & 60.37 & 6.02 & 8,760 & 52,770 & 159.50 & 20.55 & $\$ 2,216$ & $\$ 698$ & $\$ 121$ & $\$ 3,514$ & $\$ 6,307$ & $\$ 12,285$ & 1.9 \\
\hline
\end{tabular}

\begin{tabular}{|c|c|c|c|c|c|c|c|c|c|c|c|c|c|c|c|}
\hline BLDG & Floor & $\begin{array}{c}\text { Currently } \\
\text { Installed } \\
\mathrm{KW}\end{array}$ & Retrofit KW & $\begin{array}{c}\mathrm{KW} \\
\text { Savings }\end{array}$ & $\begin{array}{c}\text { Hours } \\
\text { per year }\end{array}$ & $\begin{array}{c}\text { Lighting } \\
\text { KWH Saved }\end{array}$ & $\begin{array}{l}\text { Cooling } \\
\text { MMBtu } \\
\text { Saved }\end{array}$ & $\begin{array}{c}\text { Heating } \\
\text { Ponalty } \\
\text { (MMBtu) }\end{array}$ & $\begin{array}{l}\text { Lighting \$ } \\
\text { Saved }\end{array}$ & $\begin{array}{l}\text { Cooling \$ } \\
\text { Saved }\end{array}$ & $\begin{array}{l}\text { Heating \$ } \\
\text { Penalty }\end{array}$ & $\begin{array}{c}\text { Maintenance \$ } \\
\text { Saved }\end{array}$ & Total \$ Saved & Retrofit Costs & $\begin{array}{l}\text { Payback } \\
\text { (yoars) }\end{array}$ \\
\hline 3 & FIRST FLOOR & 9.76 & 7.07 & 2.69 & 8,760 & 23,599 & 71.33 & 9.19 & $\$ 991$ & $\$ 312$ & $\$ 54$ & $\$ 2,431$ & $\$ 3,681$ & $\$ 5,392$ & 1.46 \\
\hline 3 & SECOND FLOOR & 9.60 & 7.02 & 2.58 & 8.760 & 22,627 & 68.39 & 8.81 & $\$ 950$ & $\$ 299$ & $\$ 52$ & $\$ 1,864$ & $\$ 3,061$ & $\$ 3,960$ & 1.29 \\
\hline 3 & THIRD FLOOR & 39.53 & 30.88 & 8.66 & 8,760 & 75,818 & 229.16 & 29.53 & $\$ 3,184$ & $\$ 1,003$ & $\$ 174$ & $\$ 7,999$ & $\$ 12,013$ & $\$ 16,557$ & 1.38 \\
\hline 3 & $A B / B B$ & 7.50 & 1.88 & 5.63 & 8760 & 49,275 & 148.93 & 19.19 & $\$ 2,070$ & $\$ 652$ & $\$ 113$ & $\$ 1,418$ & $\$ 4,026$ & $\$ 171$ & 0.04 \\
\hline TOTALS & & 66.39 & 46.84 & 19.56 & 8,760 & 171,319 & 517.81 & 66.73 & $\$ 7,195$ & $\$ 2,266$ & $\$ 393$ & $\$ 13,712$ & $\$ 22,781$ & $\$ 26,081$ & $\overline{1.14}$ \\
\hline
\end{tabular}

\begin{tabular}{|c|c|c|c|c|c|c|c|c|c|c|c|c|c|c|c|}
\hline BLDG & Floor & $\begin{array}{c}\text { Currently } \\
\text { Installed } \\
\mathrm{KW}\end{array}$ & Retrofit KW & $\begin{array}{c}K W \\
\text { Savings }\end{array}$ & $\begin{array}{c}\text { Hours } \\
\text { per year }\end{array}$ & $\begin{array}{c}\text { Lighting } \\
\text { KWH Saved }\end{array}$ & $\begin{array}{l}\text { Cooling } \\
\text { MMBtu } \\
\text { Saved }\end{array}$ & $\begin{array}{l}\text { Heating } \\
\text { Penalty } \\
\text { (MMBtu) }\end{array}$ & $\begin{array}{l}\text { Lighting \$ } \\
\text { Saved }\end{array}$ & $\begin{array}{l}\text { Cooling \$ } \\
\text { Saved }\end{array}$ & $\begin{array}{c}\text { Heating \$ } \\
\text { Penalty }\end{array}$ & $\begin{array}{c}\text { Maintenance \$ } \\
\text { Saved }\end{array}$ & Total \& Saved & Retrofit Costs & $\begin{array}{l}\text { Payback } \\
\text { (years) }\end{array}$ \\
\hline 3 & FIRST FLOOR & 9.76 & 4.94 & 4.82 & 8,760 & 42,258 & 127.73 & 16.46 & $\$ 1,775$ & $\$ 559$ & $\$ 97$ & $\$ 2,463$ & $\$ 4,700$ & $\$ 5,438$ & 1.16 \\
\hline 3 & SECOND FLOOR & 9.60 & 5.01 & 4.59 & 8,760 & 40,191 & 121.48 & 15.65 & $\$ 1,688$ & $\$ 532$ & $\$ 92$ & $\$ 1,888$ & $\$ 4,015$ & $\$ 5,407$ & 1.35 \\
\hline 3 & THIRD FLOOR & 39.53 & 20.23 & 19.31 & 8,760 & 169,112 & 511.14 & 65.87 & $\$ 7,103$ & $\$ 2,237$ & $\$ 387$ & $\$ 8,193$ & $\$ 17,145$ & $\$ 23,268$ & 1.36 \\
\hline 3 & $A B / B B$ & 7.50 & 1.88 & 5,63 & 8,760 & 49,275 & 148.93 & 19.19 & $\$ 2,070$ & $\$ 652$ & $\$ 113$ & $\$ 1,418$ & $\$ 4,026$ & $\$ 171$ & 0.04 \\
\hline TOTALS & & 66.39 & 32.05 & 34.34 & 8,760 & 300,836 & 909.28 & 117.17 & $\$ 12,635$ & $\$ 3,979$ & $\$ 689$ & $\$ 13,961$ & $\$ 29,886$ & $\$ 34,284$ & 1.15 \\
\hline
\end{tabular}


TABLE A.5 Cost Savings from Using Retrofit Options at Building 4

\begin{tabular}{|c|c|c|c|c|c|c|c|c|c|c|c|c|c|c|c|}
\hline BLDG & Floor & $\begin{array}{c}\text { Currently } \\
\text { Installed } \\
\mathrm{KW}\end{array}$ & Retrofit KW & $\begin{array}{c}\text { KW } \\
\text { Savings }\end{array}$ & $\begin{array}{c}\text { Hours } \\
\text { per year }\end{array}$ & $\begin{array}{c}\text { Lighting } \\
\text { KWH Saved }\end{array}$ & $\begin{array}{l}\text { Cooling } \\
\text { MMBtu } \\
\text { Saved }\end{array}$ & \begin{tabular}{|c|} 
Heating \\
Penalty \\
(MMBtu)
\end{tabular} & $\begin{array}{c}\text { Lighting \$ } \\
\text { Savod }\end{array}$ & $\begin{array}{c}\text { Cooling \$ } \\
\text { Saved }\end{array}$ & $\begin{array}{l}\text { Heating \$ } \\
\text { Penalty }\end{array}$ & $\begin{array}{l}\text { Maintenance } \\
\$ \text { Saved }\end{array}$ & $\begin{array}{l}\text { Total \$ } \\
\text { Saved }\end{array}$ & $\begin{array}{l}\text { Retrofit } \\
\text { Costs }\end{array}$ & $\begin{array}{l}\text { Payback } \\
\text { (years) }\end{array}$ \\
\hline 4 & FIAST FLOOR & 12.28 & 11.02 & 1.26 & 8.760 & 11,038 & 33.36 & 4.30 & $\$ 464$ & $\$ 146$ & $\$ 25$ & $\$ 735$ & $\$ 1,319$ & $\$ 2,570$ & 1.95 \\
\hline 4 & SECOND FLOOR & 12.26 & 11.19 & 1.07 & 8,760 & 9,356 & 28.28 & 3.64 & $\$ 393$ & $\$ 124$ & $\$ 21$ & $\$ 623$ & $\$ 1,118$ & $\$ 2,178$ & 1.95 \\
\hline 4 & THIRD FLOOR & 11.94 & 11.06 & $0.8 B$ & 8,760 & 7,726 & 23.35 & 3.01 & $\$ 325$ & $\$ 102$ & $\$ 18$ & $\$ 515$ & $\$ 924$ & $\$ 1,799$ & 1.95 \\
\hline 4 & $A B / B B$ & 0.60 & 0.60 & 0.00 & 8,760 & 0 & 0.00 & 0.00 & $\$ 0$ & $\$ 0$ & $\$ 0$ & $\$ 0$ & so & $\$ 0$ & \\
\hline \multicolumn{2}{|c|}{ TOTALS } & 37.08 & 33.87 & 3.21 & 8,760 & 28,120 & 84.99 & 10.95 & $\$ 1,181$ & $\$ 372$ & $\$ 64$ & $\$ 1,873$ & $\$ 3,361$ & $\$ 6,546$ & 1.95 \\
\hline
\end{tabular}

\begin{tabular}{|c|c|c|c|c|c|c|c|c|c|c|c|c|c|c|c|}
\hline BLDG & Floor & $\begin{array}{c}\text { Currently } \\
\text { Installed } \\
\mathrm{KW}\end{array}$ & Retrofit KW & $\begin{array}{c}\mathrm{KW} \\
\text { Savings }\end{array}$ & $\begin{array}{c}\text { Hours } \\
\text { per year }\end{array}$ & $\begin{array}{c}\text { Lighting } \\
\text { KWH Saved }\end{array}$ & $\begin{array}{l}\text { Cooling } \\
\text { MMBtu } \\
\text { Saved }\end{array}$ & $\begin{array}{c}\text { Heating } \\
\text { Penalty } \\
\text { (MMBtu) }\end{array}$ & $\begin{array}{l}\text { Lighting \$ } \\
\text { Saved }\end{array}$ & $\begin{array}{l}\text { Cooling \$ } \\
\text { Saved }\end{array}$ & $\begin{array}{l}\text { Heating \$ } \\
\text { Penalty }\end{array}$ & $\begin{array}{c}\text { Maintenance \$ } \\
\text { Saved }\end{array}$ & Total \$ Saved & $\begin{array}{l}\text { Retrofit } \\
\text { Costs }\end{array}$ & $\begin{array}{l}\text { Payback } \\
\text { (years) }\end{array}$ \\
\hline 4 & FIRST FLOOR & 12.28 & 9.03 & 3.26 & 8.760 & 28,514 & 86.18 & 11.11 & $\$ 1,198$ & $\$ 377$ & $\$ 65$ & $\$ 2,461$ & $\$ 3,970$ & $\$ 7,201$ & $\begin{array}{l}1.81 \\
1.54\end{array}$ \\
\hline 4 & SECOND FLOOR & 12.26 & 8.21 & 4.05 & 8,760 & 35,469 & 107.21 & 13.82 & $\$ 1,490$ & $\$ 469$ & $\$ 81$ & $\$ 2,491$ & $\$ 4,369$ & $\$ 6,739$ & 1.54 \\
\hline 4 & THIRD FLOOR & 11.94 & 8.22 & 3.73 & 8,760 & 32,640 & 98.65 & 12.71 & $\$ 1,371$ & $\$ 432$ & $\$ 75$ & $\$ 3,026$ & $\$ 4,754$ & $\$ 6,312$ & 1.33 \\
\hline 4 & $A B / B B$ & 0.60 & 0.15 & 0.45 & 8,760 & 3,942 & 11.91 & 1.54 & $\$ 166$ & $\$ 52$ & $\$ 9$ & $\$ 113$ & $\$ 322$ & $\$ 14$ & 0.04 \\
\hline OTAL: & & 37.08 & 25.60 & 11.48 & 8,760 & 100,565 & 303.96 & 39.17 & $\$ 4,224$ & $\$ 1,330$ & $\$ 230$ & $\$ 8,091$ & $\$ 13.415$ & $\$ 20,265$ & 1.51 \\
\hline
\end{tabular}

\begin{tabular}{|c|c|c|c|c|c|c|c|c|c|c|c|c|c|c|c|}
\hline BLDG & Floor & $\begin{array}{c}\text { Currently } \\
\text { Installed } \\
\mathrm{KW}\end{array}$ & Retrofit KW & $\begin{array}{c}\mathrm{KW} \\
\text { Savings }\end{array}$ & $\begin{array}{c}\text { Hours } \\
\text { per year }\end{array}$ & $\begin{array}{c}\text { Lighting } \\
\text { KWH Saved }\end{array}$ & $\begin{array}{l}\text { Cooling } \\
\text { MMBtu } \\
\text { Saved }\end{array}$ & $\begin{array}{c}\text { Heating } \\
\text { Penalty } \\
\text { (MMBtu) }\end{array}$ & $\begin{array}{l}\text { Lighting } \$ \\
\text { Saved }\end{array}$ & $\begin{array}{l}\text { Cooling \$ } \\
\text { Saved }\end{array}$ & $\begin{array}{c}\text { Heating } \$ \\
\text { Penalty }\end{array}$ & $\begin{array}{c}\text { Maintenance } \$ \\
\text { Saved }\end{array}$ & Total $\$$ Saved & $\begin{array}{l}\text { Retrofit } \\
\text { Costs }\end{array}$ & $\begin{array}{l}\text { Payback } \\
\text { (yøars) }\end{array}$ \\
\hline 4 & FIRST FLOOR & 12.28 & 6.27 & 6.02 & 8,760 & 52,691 & 159.26 & 20.52 & $\$ 2,213$ & $\$ 697$ & $\$ 121$ & $\$ 2,504$ & $\$ 5,293$ & $\$ 8,080$ & 1.53 \\
\hline 4 & SECOND FLOOR & 12.26 & 5.72 & 6.54 & 8,760 & 57,282 & 173.13 & 22.31 & $\$ 2,406$ & $\$ 758$ & $\$ 131$ & $\$ 2,539$ & $\$ 5,571$ & $\$ 6,812$ & 1.22 \\
\hline 4 & THIRD FLOOR & 11.94 & 6.24 & 5.71 & 8,760 & 49,985 & 151.08 & 19.47 & $\$ 2,099$ & $\$ 661$ & $\$ 115$ & $\$ 3,065$ & $\$ 5,711$ & $\$ 6,059$ & 1.06 \\
\hline 4 & $A B / B B$ & 0.60 & 0.15 & 0.45 & 8.760 & 3,942 & 11.91 & 1.54 & $\$ 166$ & $\$ 52$ & $\$ 9$ & $\$ 113$ & $\$ 322$ & $\$ 14$ & 0.04 \\
\hline TOTALS & & 37.08 & 18.37 & 18.71 & 8,760 & 163,900 & 495.39 & 63.84 & $\$ 6,884$ & $\$ 2,168$ & $\$ 376$ & $\$ 8,221$ & $\$ 16,897$ & $\$ 20,965$ & 1.24 \\
\hline
\end{tabular}


TABLE A.6 Cost Savings from Using Retrofit Options at Building 5

\begin{tabular}{|c|c|c|c|c|c|c|c|c|c|c|c|c|c|c|c|}
\hline BLDG & Floor & \begin{tabular}{c|} 
Currently \\
installed \\
$\mathrm{KW}$
\end{tabular} & Retrofit $\mathrm{KW}$ & $\begin{array}{c}\mathrm{KW} \\
\text { Savings }\end{array}$ & $\begin{array}{c}\text { Hours } \\
\text { per year }\end{array}$ & $\begin{array}{l}\text { Lighting } \\
\text { KWH Saved }\end{array}$ & $\begin{array}{l}\text { Cooling } \\
\text { MMBtu } \\
\text { Saved }\end{array}$ & $\begin{array}{c}\text { Heating } \\
\text { Penalty } \\
\text { (MMBtu) }\end{array}$ & $\begin{array}{l}\text { Lighting \$ } \\
\text { Saved }\end{array}$ & $\begin{array}{l}\text { Cooling } \$ \\
\text { Saved }\end{array}$ & $\begin{array}{l}\text { Heating \$ } \\
\text { Penalty }\end{array}$ & $\begin{array}{c}\text { Maintenance } \\
\$ \text { Saved }\end{array}$ & $\begin{array}{l}\text { Total\$ } \\
\text { Saved }\end{array}$ & $\begin{array}{l}\text { Rotrofit } \\
\text { Costs }\end{array}$ & $\begin{array}{l}\text { Payback } \\
\text { (years) }\end{array}$ \\
\hline & FIRST FLOOR & 6.62 & 5.90 & 0.72 & 8,760 & 6,307 & 19.06 & 2.46 & $\$ 265$ & $\$ 83$ & $\$ 14$ & $\$ 420$ & $\$ 754$ & $\$ 1,468$ & 1.95 \\
\hline 5 & SECOND FLOOR & 5.18 & 4.96 & 0.23 & 8,760 & 1,997 & 6.04 & 0.78 & $\$ 84$ & $\$ 26$ & $\$ 5$ & $\$ 133$ & $\$ 239$ & $\$ 465$ & 1.95 \\
\hline 5 & THIRD FLOOR & 5.57 & 4.94 & 0.63 & 8,760 & 5,519 & 16.68 & 2.15 & $\$ 232$ & $\$ 73$ & $\$ 13$ & $\$ 368$ & $\$ 660$ & $\$ 1,285$ & 1.95 \\
\hline 5 & $A B / B B$ & 0.70 & 0.70 & 0.00 & 8.760 & 0 & 0.00 & 0.00 & $\$ 0$ & $\$ 0$ & $\$ 0$ & \$o & $\$ 0$ & so & \\
\hline TOTAL. & & 18.07 & 16.50 & 1.58 & 8,760 & 13,823 & 41.78 & 5.38 & $\$ 581$ & $\$ 183$ & $\$ 32$ & $\$ 921$ & $\$ 1,652$ & $\$ 3,218$ & 1.95 \\
\hline
\end{tabular}

Intermedlate Retrofit

\begin{tabular}{|c|c|c|c|c|c|c|c|c|c|c|c|c|c|c|c|}
\hline BLDG & Floor & $\begin{array}{c}\text { Currenlly } \\
\text { Installed } \\
\mathrm{KW}\end{array}$ & Retrofit KW & $\begin{array}{c}\mathrm{kW} \\
\text { Savings }\end{array}$ & $\begin{array}{c}\text { Hours } \\
\text { per year }\end{array}$ & $\begin{array}{c}\text { Lighting } \\
\text { KWH Saved }\end{array}$ & $\begin{array}{l}\text { Cooling } \\
\text { MMBtu } \\
\text { Saved }\end{array}$ & $\begin{array}{c}\text { Heating } \\
\text { Penalty } \\
\text { (MMBiu) }\end{array}$ & $\begin{array}{l}\text { Lighting \$ } \\
\text { Saved }\end{array}$ & $\begin{array}{l}\text { Cooling \$ } \\
\text { Saved }\end{array}$ & $\begin{array}{l}\text { Heating } \$ \\
\text { Penalty }\end{array}$ & $\begin{array}{c}\text { Maintenance } \\
\text { \$ Saved }\end{array}$ & Totals Saved & $\begin{array}{l}\text { Retrofit } \\
\text { Costs }\end{array}$ & $\begin{array}{l}\text { Payback } \\
\text { (years) }\end{array}$ \\
\hline 5 & FIRST FLOOR & 6.62 & 5.21 & 1.41 & 8,760 & 12,352 & 37.33 & 4.81 & $\$ 519$ & $\$ 163$ & $\$ 28$ & $\$ 1,466$ & $\$ 2,119$ & $\$ 4,778$ & 2.25 \\
\hline 5 & SECOND FLOOR & 5.18 & 2.78 & 2.40 & 8,760 & 21,059 & 63.65 & 8.20 & $\$ 884$ & $\$ 279$ & $\$ 48$ & $\$ 1,231$ & $\$ 2,346$ & $\$ 1,610$ & 0.69 \\
\hline 5 & THIRD FLOOR & 5.57 & 4.36 & 1.22 & 8,760 & 10,643 & 32.17 & 4.15 & $\$ 447$ & $\$ 141$ & $\$ 24$ & $\$ 1,122$ & $\$ 1,685$ & $\$ 4,312$ & 2.56 \\
\hline 5 & $A B / B B$ & 0.70 & 0.18 & 0.53 & 8.760 & 4,599 & 13.90 & 1.79 & $\$ 193$ & $\$ 61$ & $\$ 11$ & $\$ 97$ & $\$ 341$ & $\$ 193$ & 0.57 \\
\hline TOTALS & & 18.07 & 12.52 & 5.55 & 8,760 & 48,653 & 147.05 & 18.95 & $\$ 2,043$ & $\$ 644$ & $\$ 111$ & $\$ 3,916$ & $\$ 6,492$ & $\$ 10,893$ & 1.68 \\
\hline
\end{tabular}

\begin{tabular}{|c|c|c|c|c|c|c|c|c|c|c|c|c|c|c|c|}
\hline BLDG & Floor & $\begin{array}{c}\text { Currently } \\
\text { Installed } \\
\mathrm{KW}\end{array}$ & Retrofit $\mathrm{KW}$ & $\begin{array}{c}\mathrm{KW} \\
\text { Savings }\end{array}$ & $\begin{array}{l}\text { Hours } \\
\text { per year }\end{array}$ & $\begin{array}{c}\text { Lighting } \\
\text { KWH Saved }\end{array}$ & $\begin{array}{l}\text { Cooling } \\
\text { MMBtu } \\
\text { Saved }\end{array}$ & $\begin{array}{l}\text { Heating } \\
\text { Penalty } \\
\text { (MMBtu) }\end{array}$ & $\begin{array}{l}\text { Lighting \$ } \\
\text { Savod }\end{array}$ & $\begin{array}{c}\text { Cooling \$ } \\
\text { Savod }\end{array}$ & $\begin{array}{l}\text { Heating \$ } \\
\text { Penalty }\end{array}$ & $\begin{array}{c}\text { Maintenance } \\
\text { \$ Saved }\end{array}$ & Total \$ Saved & $\begin{array}{l}\text { Retrofit } \\
\text { Costs }\end{array}$ & $\begin{array}{l}\text { Payback } \\
\text { (years) }\end{array}$ \\
\hline 5 & FIRST FLOOR & 6.62 & 3.47 & 3.15 & 8,760 & 27.594 & 83.40 & 10.75 & $\$ 1,159$ & $\$ 365$ & $\$ 63$ & $\$ 1.494$ & $\$ 2,955$ & $\$ 4,627$ & 1.57 \\
\hline 5 & SECOND FLOOR & 5.18 & 2.47 & 2.72 & 8,760 & 23,818 & 71.99 & 9.28 & $\$ 1,000$ & $\$ 315$ & $\$ 55$ & $\$ 1,227$ & $\$ 2,488$ & $\$ 1,964$ & 0.79 \\
\hline 5 & THIRD FLOOR & 5.57 & 2.98 & 2.60 & 8,760 & 22,732 & 68.71 & 8.85 & $\$ 955$ & $\$ 301$ & $\$ 52$ & $\$ 1,150$ & $\$ 2,353$ & $\$ 4,167$ & 1.77 \\
\hline 5 & $A B / B B$ & 0.70 & 0.18 & 0.53 & 8.760 & 4,599 & 13.90 & 1.79 & $\$ 193$ & $\$ 61$ & $\$ 11$ & $\$ 97$ & $\$ 341$ & $\$ 193$ & 0.57 \\
\hline TOTALS & & 18.07 & 9.09 & 8.99 & 8,760 & 78,744 & 238.00 & 30.67 & $\$ 3,307$ & $\$ 1,042$ & $\$ 180$ & $\$ 3,968$ & $\$ 8,137$ & $\$ 10,951$ & 1.35 \\
\hline
\end{tabular}


TABLE A.7 Cost Savings from Using Retrofit Options at Building 6

\begin{tabular}{|c|c|c|c|c|c|c|c|c|c|c|c|c|c|c|c|}
\hline$B L D G$ & Floor & $\begin{array}{c}\text { Currently } \\
\text { Installed } \\
\mathrm{KW}\end{array}$ & Retrofit $\mathrm{KW}$ & $\begin{array}{c}\mathrm{KW} \\
\text { Savings }\end{array}$ & $\begin{array}{c}\text { Hours } \\
\text { per year }\end{array}$ & $\begin{array}{c}\text { Lighting } \\
\text { KWH Saved }\end{array}$ & $\begin{array}{l}\text { Cooling } \\
\text { MMBlu } \\
\text { Saved }\end{array}$ & \begin{tabular}{|c|} 
Heating \\
Penalty \\
(MMBtu)
\end{tabular} & $\begin{array}{l}\text { Lighting \$ } \\
\text { Saved }\end{array}$ & $\begin{array}{l}\text { Cooling } \$ \\
\text { Saved }\end{array}$ & $\begin{array}{l}\text { Heating \$ } \\
\text { Penalty }\end{array}$ & $\begin{array}{c}\text { Maintenance \$ } \\
\text { Saved }\end{array}$ & $\begin{array}{l}\text { Total \$ } \\
\text { Saved }\end{array}$ & $\begin{array}{l}\text { Retrofit } \\
\text { Costs }\end{array}$ & $\begin{array}{l}\text { Payback } \\
\text { (years) }\end{array}$ \\
\hline 6 & FIRST FLOOR & 2.99 & 2.74 & 0.26 & 8,760 & 2,260 & 6.83 & 0.88 & $\$ 95$ & $\$ 30$ & $\$ 5$ & $\$ 151$ & $\$ 270$ & $\$ 526$ & 1.95 \\
\hline 6 & SECOND FLOOR & 4.62 & 4.12 & 0.49 & 8,760 & 4.310 & 13.03 & 1.68 & $\$ 181$ & $\$ 57$ & $\$ 10$ & $\$ 287$ & $\$ 515$ & $\$ 1,003$ & 1.95 \\
\hline 6 & THIRO FLOOR & 4.97 & 4.44 & 0.53 & 8,760 & 4,678 & 14.14 & 1.82 & $\$ 196$ & $\$ 62$ & $\$ 11$ & $\$ 312$ & $\$ 559$ & $\$ 1,089$ & 1.95 \\
\hline 6 & $A B / B B$ & 0.60 & 0.60 & 0.00 & 8,760 & 0 & 0.00 & 0.00 & $\$ 0$ & $\$ 0$ & $\$ 0$ & $\$ 0$ & $\$ 0$ & $\$ 0$ & \\
\hline DTALS & & 13.18 & 11.90 & 1.28 & 8,760 & 11,248 & 34.00 & 4.38 & $\$ 472$ & $\$ 149$ & $\$ 26$ & $\$ 749$ & $\$ 1,344$ & $\$ 2,618$ & 1.95 \\
\hline
\end{tabular}

\begin{tabular}{|c|c|c|c|c|c|c|c|c|c|c|c|c|c|c|c|}
\hline BLDG & Floor & \begin{tabular}{|c|}
$\begin{array}{c}\text { Currently } \\
\text { Installed } \\
\mathrm{KW}\end{array}$ \\
\end{tabular} & Retrofit KW & $\begin{array}{c}\text { KW } \\
\text { Savings }\end{array}$ & $\begin{array}{l}\text { Hours } \\
\text { per year }\end{array}$ & $\begin{array}{c}\text { Lighting } \\
\text { KWH Savod }\end{array}$ & $\begin{array}{l}\text { Cooling } \\
\text { MMBtu } \\
\text { Saved }\end{array}$ & $\begin{array}{l}\text { heating } \\
\text { Penally } \\
\text { (MMBtu) }\end{array}$ & $\begin{array}{l}\text { Lighting \$ } \\
\text { Saved }\end{array}$ & $\begin{array}{l}\text { Cooling } \$ \\
\text { Saved }\end{array}$ & $\begin{array}{c}\text { Heating } \$ \\
\text { Penally }\end{array}$ & $\begin{array}{c}\text { Maintenance \$ } \\
\text { Saved }\end{array}$ & Total \$ Saved & $\begin{array}{l}\text { Rotrolit } \\
\text { Costs }\end{array}$ & $\begin{array}{l}\text { Payback } \\
\text { (years) }\end{array}$ \\
\hline 6 & FIRST FLOOR & 2.99 & 2.05 & 0.94 & 8,760 & 8,269 & 24.99 & 3.22 & $\$ 347$ & $\$ 109$ & $\$ 19$ & $\$ 602$ & $\$ 1,040$ & $\$ 1,460$ & 1.40 \\
\hline 6 & SECOND FLOOR & 4.62 & 3.51 & 1.11 & 8,760 & 9,689 & 29.28 & 3.77 & $\$ 407$ & $\$ 128$ & $\$ 22$ & $\$ 971$ & $\$ 1,484$ & $\$ 3,544$ & 2.39 \\
\hline 6 & THIRD FLOOR & 4.97 & 3.81 & 1.16 & 8,760 & 10,179 & 30.77 & 3.96 & $\$ 428$ & $\$ 135$ & $\$ 23$ & $\$ 974$ & $\$ 1,513$ & $\$ 2,451$ & 1,62 \\
\hline 6 & $\mathrm{AB} / \mathrm{BB}$ & 0.60 & 0.15 & 0.45 & 8,760 & 3,942 & 11.91 & 1.54 & $\$ 166$ & $\$ 52$ & $\$ 9$ & $\$ 83$ & $\$ 292$ & $\$ 165$ & 0.57 \\
\hline OTALS & & 13.18 & 9.52 & 3.66 & 8,760 & 32,079 & 96.96 & 12.49 & $\$ 1,347$ & $\$ 424$ & $\$ 73$ & $\$ 2,630$ & $\$ 4,328$ & $\$ 7,620$ & 1.76 \\
\hline
\end{tabular}

\begin{tabular}{|c|c|c|c|c|c|c|c|c|c|c|c|c|c|c|c|}
\hline BLDG & Floor & $\begin{array}{c}\text { Currently } \\
\text { Installed } \\
\mathrm{KW}\end{array}$ & Retrofit KW & $\begin{array}{c}\mathrm{KW} \\
\text { Savings }\end{array}$ & $\begin{array}{c}\text { Hours } \\
\text { per year }\end{array}$ & $\begin{array}{c}\text { Lighting } \\
\text { KWH Saved }\end{array}$ & $\begin{array}{l}\text { Cooling } \\
\text { MMBtu } \\
\text { Saved }\end{array}$ & $\begin{array}{c}\text { Healing } \\
\text { Penalty } \\
\text { (MMBtu) }\end{array}$ & $\begin{array}{l}\text { Lighting } \$ \\
\text { Saved }\end{array}$ & $\begin{array}{l}\text { Cooling } \$ \\
\text { Saved }\end{array}$ & $\begin{array}{c}\text { Heating \$ } \\
\text { Penalty }\end{array}$ & $\begin{array}{c}\text { Maintenance \$ } \\
\text { Saved }\end{array}$ & Total \$ Saved & $\begin{array}{l}\text { Retrofit } \\
\text { Costs }\end{array}$ & $\begin{array}{l}\text { Payback } \\
\text { (years) }\end{array}$ \\
\hline 6 & FIRST FLOOR & 2.99 & 1.51 & 1.48 & 8,760 & 13,000 & 39.29 & 5.06 & $\$ 546$ & $\$ 172$ & $\$ 30$ & $\$ 608$ & $\$ 1,296$ & $\$ 1.793$ & 1.38 \\
\hline 6 & SECOND FLOOR & 4.62 & 2.49 & 2.13 & 8,760 & 18,624 & 56.29 & 7.25 & $\$ 782$ & $\$ 246$ & $\$ 43$ & $\$ 983$ & $\$ 1,969$ & $\$ 3,506$ & 1.78 \\
\hline 6 & THIRD FLOOR & 4.97 & 2.61 & 2.36 & 8,760 & 20,691 & 62.54 & 8.06 & $\$ 869$ & $\$ 274$ & $\$ 47$ & $\$ 996$ & $\$ 2,092$ & $\$ 3,219$ & 1.54 \\
\hline 6 & AB/BB & 0.60 & 0.15 & 0.45 & 8,760 & 3,942 & 11.91 & 1.54 & $\$ 166$ & $\$ 52$ & $\$ 9$ & $\$ 83$ & $\$ 292$ & $\$ 165$ & 0.57 \\
\hline TOTALS & & 13.18 & 6.76 & 6.42 & 8,760 & 56,257 & 170.04 & 21.91 & $\$ 2,363$ & $\$ 744$ & $\$ 129$ & $\$ 2,670$ & $\$ 5,648$ & $\$ 8,683$ & 1.54 \\
\hline
\end{tabular}


TABLE A.8 Cost Savings from Using Retrofit Options at Building 7

\begin{tabular}{|c|c|c|c|c|c|c|c|c|c|c|c|c|c|c|c|}
\hline BLDG & Floor & $\begin{array}{c}\text { Currently } \\
\text { Installed } \\
\mathrm{KW}\end{array}$ & Retrofit KW & $\begin{array}{c}\text { KW } \\
\text { Savings }\end{array}$ & $\begin{array}{l}\text { Hours } \\
\text { per year }\end{array}$ & $\begin{array}{c}\text { Lighting } \\
\text { KWH Saved }\end{array}$ & $\begin{array}{l}\text { Cooling } \\
\text { MMBtu } \\
\text { Saved }\end{array}$ & $\begin{array}{c}\text { Heating } \\
\text { Penalty } \\
\text { (MMB(u) }\end{array}$ & $\begin{array}{l}\text { Lighting \$ } \\
\text { Saved }\end{array}$ & $\begin{array}{l}\text { Cooling \$. } \\
\text { Saved }\end{array}$ & $\begin{array}{l}\text { Heating \$ } \\
\text { Penalty }\end{array}$ & $\begin{array}{c}\text { Maintenance } \$ \\
\text { Saved }\end{array}$ & $\begin{array}{l}\text { Total \$ } \\
\text { Saved }\end{array}$ & $\begin{array}{l}\text { Retrofit } \\
\text { Costs }\end{array}$ & $\begin{array}{l}\text { Payback } \\
\text { (years) }\end{array}$ \\
\hline 7 & FIRST FLOOR & 5.34 & 4.79 & 0.56 & 8,760 & 4,888 & 14.77 & 1.90 & $\$ 205$ & $\$ 65$ & $\$ 11$ & $\$ 326$ & $\$ 584$ & $\$ 1,138$ & 1.95 \\
\hline 7 & SECOND FLOOR & 6.96 & 6.74 & 0.22 & 8,760 & 1,892 & 5.72 & 0.74 & $\$ 79$ & $\$ 25$ & $\$ 4$ & $\$ 126$ & $\$ 226$ & $\$ 440$ & 1.95 \\
\hline 7 & THIRD FLOOR & 5.92 & 5.35 & 0.57 & 8,760 & 4,993 & 15.09 & 1.94 & $\$ 210$ & $\$ 66$ & $\$ 11$ & $\$ 333$ & $\$ 597$ & $\$ 1,162$ & 1.95 \\
\hline 7 & $A B / B B$ & 0.80 & 0.80 & 0.00 & 8.760 & 0 & 0.00 & 0.00 & $\$ 0$ & $\$ 0$ & $\$ 0$ & $\$ 0$ & $\$ 0$ & $\$ 0$ & \\
\hline TOTALS & & 19.02 & 17.68 & 1.34 & 8,760 & 11,773 & 35.59 & 4.59 & $\$ 494$ & $\$ 156$ & $\$ 27$ & $\$ 784$ & $\$ 1,407$ & $\$ 2,741$ & 1.95 \\
\hline
\end{tabular}

Intermedlate Retrofit

\begin{tabular}{|c|c|c|c|c|c|c|c|c|c|c|c|c|c|c|c|}
\hline BLDG & Floor & $\begin{array}{c}\text { Currently } \\
\text { Installed } \\
\mathrm{KW}\end{array}$ & Rotrofit KW & $\begin{array}{c}\mathrm{KW} \\
\text { Savings }\end{array}$ & $\begin{array}{c}\text { Hours } \\
\text { per year }\end{array}$ & $\begin{array}{c}\text { Lighting } \\
\text { KWH Saved }\end{array}$ & $\begin{array}{l}\text { Cooling } \\
\text { MMBtu } \\
\text { Saved }\end{array}$ & \begin{tabular}{|c|} 
Healing \\
Penalty \\
(MMBtu)
\end{tabular} & $\begin{array}{l}\text { Lighting \$ } \\
\text { Saved }\end{array}$ & $\begin{array}{l}\text { Cooling } \$ \\
\text { Saved }\end{array}$ & $\begin{array}{l}\text { Heating \$ } \\
\text { Penalty }\end{array}$ & $\begin{array}{c}\text { Maintenance \$ } \\
\text { Saved }\end{array}$ & Total S Saved & $\begin{array}{l}\text { Retrofit } \\
\text { Costs }\end{array}$ & $\begin{array}{l}\text { Payback } \\
\text { (years) }\end{array}$ \\
\hline 7 & FIRST FLOOR & 5.34 & 4.15 & 1.19 & 8,760 & 10,459 & 31.61 & 4.07 & $\$ 439$ & $\$ 138$ & $\$ 24$ & $\$ 1,258$ & $\$ 1,811$ & $\$ 3,854$ & 2.13 \\
\hline 7 & SECOND FLOOR & 6.96 & 3.05 & 3.91 & 8.760 & 34,278 & 103.60 & 13.35 & $\$ 1,440$ & $\$ 453$ & $\$ 79$ & $\$ 1,195$ & $\$ 3,010$ & $\$ 2,258$ & 0.75 \\
\hline 7 & THIRD FLOOR & 5.92 & 4.41 & 1.51 & 8.760 & 13,228 & 39.98 & 5.15 & $\$ 556$ & $\$ 175$ & $\$ 30$ & $\$ 1,327$ & $\$ 2,027$ & $\$ 3,572$ & 1.76 \\
\hline 7 & $A B / B B$ & 0.80 & 0.20 & 0.60 & 8.760 & 5,256 & 15.89 & 2.05 & $\$ 221$ & $\$ 70$ & $\$ 12$ & $\$ 111$ & $\$ 389$ & $\$ 221$ & 0.57 \\
\hline TOTALS & & 19.02 & 11.81 & 7.22 & 8,760 & 63,221 & 191.09 & 24.62 & $\$ 2,655$ & $\$ 836$ & $\$ 145$ & $\$ 3,891$ & $\$ 7,237$ & $\$ 9,905$ & 1.37 \\
\hline
\end{tabular}

Advanced Petrofit

\begin{tabular}{|c|c|c|c|c|c|c|c|c|c|c|c|c|c|c|c|}
\hline BLDG & Floor & \begin{tabular}{|c|}
$\begin{array}{c}\text { Currenily } \\
\text { Installed } \\
\mathrm{KW}\end{array}$ \\
\end{tabular} & Retrofit KW & $\begin{array}{c}\mathrm{KW} \\
\text { Savings }\end{array}$ & $\begin{array}{c}\text { Hours } \\
\text { per year }\end{array}$ & $\begin{array}{c}\text { Lighting } \\
\text { KWH Saved }\end{array}$ & $\begin{array}{l}\text { Cooling } \\
\text { MMBtu } \\
\text { Saved }\end{array}$ & $\begin{array}{c}\text { Heating } \\
\text { Penalty } \\
\text { (MMBtu) }\end{array}$ & $\begin{array}{l}\text { Lighting \$ } \\
\text { Savod }\end{array}$ & $\begin{array}{l}\text { Cooling \$ } \\
\text { Saved }\end{array}$ & $\begin{array}{l}\text { Heating } \$ \\
\text { Penalty }\end{array}$ & $\begin{array}{c}\text { Maintenance } \$ \\
\text { Saved }\end{array}$ & Total \$ Saved & $\begin{array}{l}\text { Retrofit } \\
\text { Costs }\end{array}$ & $\begin{array}{l}\text { Payback } \\
\text { (years) }\end{array}$ \\
\hline 7 & FIRST FLOOR & 5.34 & 2.92 & 2.42 & 8,760 & 21,234 & 64.18 & 8.27 & $\$ 892$ & $\$ 281$ & $\$ 49$ & $\$ 1,283$ & $\$ 2,407$ & $\$ 3,708$ & 1.54 \\
\hline 7 & SECOND FLOOR & 6.96 & 2.69 & 4.27 & 8.760 & 37,431 & 113.14 & 14.58 & $\$ 1,572$ & $\$ 495$ & $\$ 86$ & $\$ 1,196$ & $\$ 3,177$ & $\$ 2,296$ & 0.72 \\
\hline 7 & THIRD FLOOR & 5.92 & 3.00 & 2.92 & 8,760 & 25,579 & 77.31 & 9.96 & $\$ 1,074$ & $\$ 338$ & $\$ 59$ & $\$ 1,357$ & $\$ 2,711$ & $\$ 3,543$ & 1.31 \\
\hline 7 & $A B / B B$ & 0.80 & 0.20 & 0.60 & 8,760 & 5,256 & 15.89 & 2.05 & $\$ 221$ & $\$ 70$ & $\$ 12$ & $\$ 111$ & $\$ 389$ & $\$ 221$ & 0.57 \\
\hline OTALS & & 19.02 & 8.81 & 10.22 & 8,760 & 89,501 & 270.52 & 34.86 & $\$ 3,759$ & $\$ 1,184$ & $\$ 205$ & $\$ 3,947$ & $\$ 8,685$ & $\$ 9,767$ & 1.12 \\
\hline
\end{tabular}


TABLE A.9 Cost Savings from Using Retrofit Options at Building 8

\begin{tabular}{|c|c|c|c|c|c|c|c|c|c|c|c|c|c|c|c|}
\hline BLDG & Floor & $\begin{array}{c}\text { Currently } \\
\text { Installed } \\
\mathrm{KW}\end{array}$ & Retrofit KW & $\begin{array}{c}K W \\
\text { Savings }\end{array}$ & $\begin{array}{c}\text { Hours } \\
\text { per year }\end{array}$ & $\begin{array}{c}\text { Lighting } \\
\text { KWH Saved }\end{array}$ & $\begin{array}{l}\text { Cooling } \\
\text { MMBtu } \\
\text { Saved }\end{array}$ & \begin{tabular}{|c|} 
Hoating \\
Penalty \\
(MMBiu)
\end{tabular} & $\begin{array}{l}\text { Lighting \$ } \\
\text { Saved }\end{array}$ & $\begin{array}{c}\text { Cooling \$ } \\
\text { Saved }\end{array}$ & $\begin{array}{c}\text { Heating \$ } \\
\text { Penalty }\end{array}$ & $\begin{array}{c}\text { Maintenance } \\
\text { \$ Saved }\end{array}$ & $\begin{array}{l}\text { Total \$ } \\
\text { Savod }\end{array}$ & $\begin{array}{l}\text { Retrofit } \\
\text { Costs }\end{array}$ & $\begin{array}{l}\text { Payback } \\
\text { (years) }\end{array}$ \\
\hline 8 & FIRSTFLOOR & 13.72 & 12.11 & 1.60 & 8,760 & 14,034 & 42.42 & 5.47 & $\$ 589$ & $\$ 186$ & $\$ 32$ & $\$ 935$ & $\$ 1,677$ & $\$ 3,267$ & 1.95 \\
\hline 8 & SECOND FLOOR & 5.56 & 5.12 & 0.43 & 8,760 & 3,784 & 11.44 & 1.47 & $\$ 159$ & $\$ 50$ & $\$ 9$ & $\$ 252$ & $\$ 452$ & $\$ 881$ & 1.95 \\
\hline 8 & THIIRD FLOOR & 10.26 & 9.21 & 1.05 & 8,760 & 9,198 & 27.80 & 3.58 & $\$ 386$ & $\$ 122$ & $\$ 21$ & $\$ 613$ & $\$ 1,099$ & $\$ 2,141$ & 1.95 \\
\hline 8 & $\mathrm{AB} / \mathrm{BB}$ & 1.10 & 1.10 & 0.00 & 8,760 & 0 & 0.00 & 0.00 & $\$ 0$ & $\$ 0$ & $\$ 0$ & $\$ 0$ & so & $\$ 0$ & \\
\hline TTI & & 30.63 & 27.55 & 3.08 & 8,760 & 27,016 & 81.66 & 10.52 & $\$ 1,135$ & $\$ 357$ & $\$ 62$ & $\$ 1,799$ & $\$ 3,229$ & $\$ 6,289$ & 10 \\
\hline
\end{tabular}

\begin{tabular}{|c|c|c|c|c|c|c|c|c|c|c|c|c|c|c|c|}
\hline BLDG & Floor & $\begin{array}{c}\text { Currently } \\
\text { Installed } \\
\mathrm{KW}\end{array}$ & Retrofit KW & $\begin{array}{c}\mathrm{KW} \\
\text { Savings }\end{array}$ & $\begin{array}{l}\text { Hours } \\
\text { per year }\end{array}$ & $\begin{array}{c}\text { Lighting } \\
\text { KWH Savod }\end{array}$ & $\begin{array}{l}\text { Cooling } \\
\text { MMBtu } \\
\text { Saved }\end{array}$ & \begin{tabular}{|c|} 
Heating \\
Penaity \\
(MMBtu)
\end{tabular} & $\begin{array}{l}\text { Lighting \$ } \\
\text { Saved }\end{array}$ & $\begin{array}{c}\text { Cooling } \$ \\
\text { Saved }\end{array}$ & $\begin{array}{l}\text { Heating \$ } \\
\text { Penalty }\end{array}$ & $\begin{array}{l}\text { Maintenance } \\
\text { \$ Saved }\end{array}$ & Total \$ Saved & $\begin{array}{l}\text { Retrofit } \\
\text { Cosis }\end{array}$ & $\begin{array}{l}\text { Payback } \\
\text { (years) }\end{array}$ \\
\hline 8 & FIRST FLOOR & 13.72 & 11.06 & 2.66 & 8,760 & 23,310 & 70.46 & 9.08 & $\$ 979$ & $\$ 308$ & $\$ 53$ & $\$ 2,584$ & $\$ 3,818$ & $\$ 6,245$ & 1.64 \\
\hline 8 & SECOND FLOOR & 5.56 & 3.56 & 2.00 & 8,760 & 17,529 & 52.98 & 6.83 & $\$ 736$ & $\$ 232$ & $\$ 40$ & $\$ 1,191$ & $\$ 2,119$ & $\$ 3,099$ & 1.46 \\
\hline 8 & THIRD FLOOR & 10.26 & 7.64 & 2.63 & 8,760 & 22,995 & 69.50 & 8.96 & $\$ 966$ & $\$ 304$ & $\$ 53$ & $\$ 2,147$ & $\$ 3,365$ & $\$ 7,009$ & 2.08 \\
\hline 8 & $A B / B B$ & 1.10 & 0.28 & 0.83 & 8,760 & 7,227 & 21.84 & 2.81 & $\$ 304$ & $\$ 96$ & $\$ 17$ & $\$ 153$ & $\$ 535$ & $\$ 303$ & 0.57 \\
\hline TOTALS & & 30.63 & 22.52 & 8.11 & 8,760 & 71.061 & 214.78 & 27.68 & $\$ 2,985$ & $\$ 940$ & $\$ 163$ & $\$ 6,075$ & $\$ 9,837$ & $\$ 16,656$ & 1.69 \\
\hline
\end{tabular}

\begin{tabular}{|c|c|c|c|c|c|c|c|c|c|c|c|c|c|c|c|}
\hline BLDG & Floor & $\begin{array}{c}\text { Currently } \\
\text { Installed } \\
\mathrm{KW}\end{array}$ & Rotrofit KW & $\begin{array}{c}\mathrm{KW} \\
\text { Savings }\end{array}$ & $\begin{array}{c}\text { Hours } \\
\text { per year }\end{array}$ & $\begin{array}{c}\text { Lighting } \\
\text { KWH Saved }\end{array}$ & $\begin{array}{l}\text { Cooling } \\
\text { MMBtu } \\
\text { Saved }\end{array}$ & \begin{tabular}{|c|} 
Heating \\
Penalty \\
(MMBtu)
\end{tabular} & $\begin{array}{l}\text { Lighting } \$ \\
\text { Saved }\end{array}$ & $\begin{array}{l}\text { Cooling } \$ \\
\text { Saved }\end{array}$ & $\begin{array}{c}\text { Heating \$ } \\
\text { Penalty }\end{array}$ & $\begin{array}{c}\text { Maintenance } \\
\text { \$ Saved }\end{array}$ & Total \$ Savod & $\begin{array}{l}\text { Retrofit } \\
\text { Costs }\end{array}$ & $\begin{array}{l}\text { Payback } \\
\text { (years) }\end{array}$ \\
\hline 8 & FIRST FLOOR & 13.72 & 7.10 & 6.62 & 8,760 & 58.000 & 175.31 & 22.59 & $\$ 2,436$ & $\$ 767$ & $\$ 133$ & $\$ 2.651$ & $\$ 5,722$ & $\$ 8,854$ & 1.55 \\
\hline 8 & SECOND FLOOR & 5,56 & 2.51 & 3.05 & 8,760 & 26,727 & 80.78 & 10.41 & $\$ 1,123$ & $\$ 354$ & $\$ 61$ & $\$ 1,205$ & $\$ 2,620$ & $\$ 3,042$ & 1.16 \\
\hline 8 & THIRD FLOOR & 10.26 & 5.03 & 5.24 & 8,760 & 45,859 & 138.61 & 17.86 & $\$ 1,926$ & $\$ 607$ & $\$ 105$ & $\$ 2,201$ & $\$ 4,628$ & $\$ 6,674$ & 1.44 \\
\hline 8 & $A B / B B$ & 1.10 & 0.28 & 0.83 & 8.760 & 7,227 & 21.84 & 2,81 & $\$ 304$ & $\$ 96$ & $\$ 17$ & $\$ 153$ & $\$ 535$ & $\$ 303$ & 0.57 \\
\hline TOTAL & & 30.63 & 14.90 & 15.73 & 8,760 & 137,812 & 416.54 & 53.68 & $\$ 5,788$ & $\$ 1,823$ & $\$ 316$ & $\$ 6,210$ & $\$ 13,505$ & $\$ 18,874$ & 1.40 \\
\hline
\end{tabular}


TABLE A.10 Cost Savings from Using Retrofit Options at Building 9

\begin{tabular}{|c|c|c|c|c|c|c|c|c|c|c|c|c|c|c|c|}
\hline BLDG & Floor & $\begin{array}{c}\text { Currently } \\
\text { Instailed } \\
\mathrm{KW}\end{array}$ & Retrofit KW & $\begin{array}{c}\text { KW } \\
\text { Savings }\end{array}$ & $\begin{array}{c}\text { Hours } \\
\text { per year }\end{array}$ & $\begin{array}{c}\text { Lighting } \\
\text { KWH Saved }\end{array}$ & $\begin{array}{l}\text { Cooling } \\
\text { MMBtu } \\
\text { Saved }\end{array}$ & $\begin{array}{l}\text { Heating } \\
\text { Penalty } \\
\text { (MMBlu) }\end{array}$ & $\begin{array}{l}\text { Lighting \$ } \\
\text { Saved }\end{array}$ & $\begin{array}{c}\text { Cooling \$ } \\
\text { Saved }\end{array}$ & $\begin{array}{l}\text { Heating \$ } \\
\text { Penalty }\end{array}$ & $\begin{array}{c}\text { Maintenance } \\
\text { \$ Saved }\end{array}$ & $\begin{array}{l}\text { Total \$ } \\
\text { Saved }\end{array}$ & $\begin{array}{l}\text { Retrofit } \\
\text { Costs }\end{array}$ & $\begin{array}{l}\text { Payback } \\
\text { (years) }\end{array}$ \\
\hline 9 & FIRST FLOOR & 12.73 & 11.49 & 1.25 & 8,760 & 10,932 & 33.04 & 4.26 & $\$ 459$ & $\$ 145$ & $\$ 25$ & $\$ 728$ & $\$ 1,307$ & $\$ 2,545$ & 1.95 \\
\hline 9 & SECOND FLOOA & 12.72 & 11.44 & 1.28 & 8,760 & 11,248 & 34.00 & 4.38 & $\$ 472$ & $\$ 149$ & $\$ 26$ & $\$ 749$ & $\$ 1,344$ & $\$ 2,618$ & 1.95 \\
\hline 9 & THIRD FLOOR & 13.06 & 11.58 & 1.48 & 8,760 & 12,930 & 39.08 & 5.04 & $\$ 543$ & $\$ 171$ & $\$ 30$ & $\$ 861$ & $\$ 1,545$ & $\$ 3,010$ & 1.95 \\
\hline 9 & AB/BB & 0.90 & 0.90 & 0.00 & 8,760 & 0 & 0.00 & 0.00 & $\$ 0$ & $\$ 0$ & $\$ 0$ & $\$ 0$ & $\$ 0$ & $\$ 0$ & \\
\hline OTAL: & & 39.41 & 35.41 & 4.01 & 8,760 & 35,110 & 106.12 & 13.68 & $\$ 1,475$ & $\$ 464$ & $\$ 80$ & $\$ 2,338$ & $\$ 4,197$ & $\$ 8,173$ & 1.95 \\
\hline
\end{tabular}

Intermediate Retrofit

\begin{tabular}{|c|c|c|c|c|c|c|c|c|c|c|c|c|c|c|c|}
\hline BLDG & Floor & $\begin{array}{c}\text { Currently } \\
\text { Instailled } \\
\mathrm{KW}\end{array}$ & Retrolit KW & $\begin{array}{c}\mathrm{KW} \\
\text { Savings }\end{array}$ & $\begin{array}{c}\text { Hours } \\
\text { per year }\end{array}$ & $\begin{array}{c}\text { Lighting } \\
\text { KWH Saved }\end{array}$ & $\begin{array}{l}\text { Cooling } \\
\text { MMBtu } \\
\text { Saved }\end{array}$ & \begin{tabular}{|c|} 
Heating \\
Penalty \\
(MMBtu)
\end{tabular} & $\begin{array}{l}\text { Llghting \$ } \\
\text { Saved }\end{array}$ & $\begin{array}{c}\text { Coolling } \$ \\
\text { Saved }\end{array}$ & $\begin{array}{c}\text { Heating \$ } \\
\text { Penalty }\end{array}$ & $\begin{array}{c}\text { Maintenance } \$ \\
\text { Saved }\end{array}$ & Total \$ Saved & $\begin{array}{l}\text { Retrofit } \\
\text { Costs }\end{array}$ & $\begin{array}{l}\text { Payback } \\
\text { (years) }\end{array}$ \\
\hline 9 & FIRST FLOOR & 12.73 & 9.20 & 3.54 & 8,760 & 31.002 & 93.70 & 12.08 & $\$ 1,302$ & $\$ 410$ & $\$ 71$ & $\$ 2,759$ & $\$ 4,400$ & $\$ 8,329$ & 1.89 \\
\hline 9 & SECOND FLOOR & 12.72 & 9.74 & 2.99 & 8,760 & 26,166 & 79.09 & 10.19 & $\$ 1,099$ & $\$ 346$ & $\$ 60$ & $\$ 3,046$ & $\$ 4,431$ & $\$ 8,563$ & 1.93 \\
\hline 9 & THIRD FLOOR & 13.06 & 10.34 & 2.72 & 8,760 & 23,810 & 71.96 & 9.27 & $\$ 1,000$ & $\$ 315$ & $\$ 55$ & $\$ 2,621$ & $\$ 3,881$ & $\$ 7,313$ & 1.88 \\
\hline 9 & $A B / B B$ & 0.90 & 0.23 & 0.68 & 8.760 & 5,913 & 17.87 & 2.30 & $\$ 248$ & $\$ 78$ & $\$ 14$ & $\$ 125$ & $\$ 438$ & $\$ 248$ & 0.57 \\
\hline TOTALS & & 39.41 & 29.50 & 9.92 & 8,760 & 86,890 & 262.63 & 33.84 & $\$ 3,649$ & $\$ 1.149$ & $\$ 199$ & $\$ 8,550$ & $\$ 13,150$ & $\$ 24,453$ & 1.86 \\
\hline
\end{tabular}

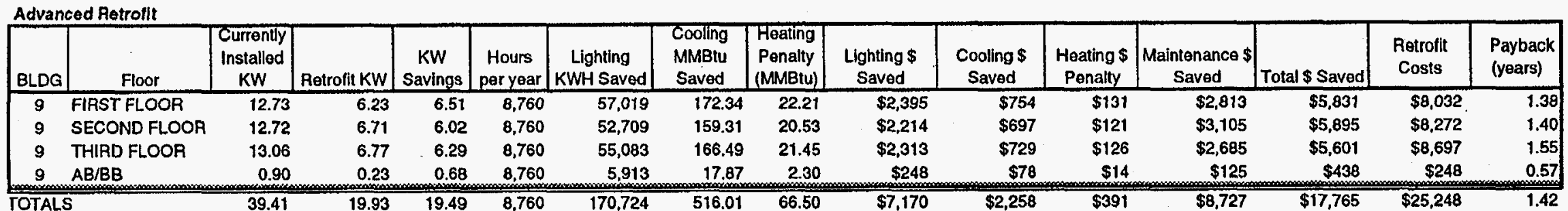


TABLE A.11 Cost Savings from Using Retrofit Options at Building 10

\begin{tabular}{|c|c|c|c|c|c|c|c|c|c|c|c|c|c|c|c|}
\hline BLDG & Floor & $\begin{array}{c}\text { Curronity } \\
\text { Installed } \\
\mathrm{KW}\end{array}$ & Retrofit KW & $\begin{array}{c}\text { KW } \\
\text { Savings }\end{array}$ & $\begin{array}{c}\text { Hours } \\
\text { per year }\end{array}$ & $\begin{array}{c}\text { Lighting } \\
\text { KWH Saved }\end{array}$ & $\begin{array}{l}\text { Cooling } \\
\text { MMBtu } \\
\text { Saved }\end{array}$ & $\begin{array}{l}\text { Heating } \\
\text { Penalty } \\
\text { (MMBtu) }\end{array}$ & $\begin{array}{l}\text { Lighting } \$ \\
\text { Saved }\end{array}$ & $\begin{array}{c}\text { Cooling } \$ \\
\text { Saved }\end{array}$ & $\begin{array}{l}\text { Heating \$ } \\
\text { Penalty }\end{array}$ & $\begin{array}{l}\text { Maintenance } \\
\$ \text { Saved }\end{array}$ & $\begin{array}{l}\text { Total \$ } \\
\text { Saved }\end{array}$ & $\begin{array}{l}\text { Petrofit } \\
\text { Costs }\end{array}$ & $\begin{array}{l}\text { Payback } \\
\text { (years) }\end{array}$ \\
\hline 10 & FIRST FLOOA & 4.19 & 3.85 & 0.35 & 8,760 & 3,048 & 9.21 & 1.19 & $\$ 128$ & $\$ 40$ & $\$ 7$ & $\$ 203$ & $\$ 364$ & $\$ 709.67$ & 1.95 \\
\hline 10 & SECOND FLOOR & 7.77 & 7.21 & 0.56 & 8,760 & 4,941 & 14.93 & 1.92 & $\$ 208$ & $\$ 65$ & $\$ 11$ & $\$ 329$ & $\$ 591$ & $\$ 1,150.16$ & 1.95 \\
\hline 10 & THIRD FLOOR & 8.17 & 7.19 & 0.98 & 8,760 & 8,620 & 26.05 & 3.36 & $\$ 362$ & $\$ 114$ & $\$ 20$ & $\$ 574$ & $\$ 1.030$ & $\$ 2,006.66$ & 1.95 \\
\hline 10 & $A B / B B$ & 1.00 & 1.00 & 0.00 & 8.760 & 0 & 0.00 & 0.00 & $\$ 0$ & $\$ 0$ & $\$ 0$ & $\$ 0$ & $\$ 0$ & $\$$ & \\
\hline OTAL & & 21.14 & 19.24 & 1.90 & 8,760 & 16,609 & 50.20 & 6.47 & $\$ 698$ & $\$ 220$ & $\$ 38$ & $\$ 1,106$ & 1,985 & 6.49 & 1.95 \\
\hline
\end{tabular}

Intermedlate Retrofit

\begin{tabular}{|c|c|c|c|c|c|c|c|c|c|c|c|c|c|c|c|}
\hline BLDG & Floor & $\begin{array}{c}\begin{array}{c}\text { Currently } \\
\text { Installed } \\
\mathrm{KW}\end{array} \\
\end{array}$ & Retrofit KW & $\begin{array}{c}\mathrm{KW} \\
\text { Savings }\end{array}$ & $\begin{array}{c}\text { Hours } \\
\text { per year }\end{array}$ & $\begin{array}{l}\text { Lighting } \\
\text { KWH Saved }\end{array}$ & $\begin{array}{l}\text { Cooling } \\
\text { MMBtu } \\
\text { Saved }\end{array}$ & $\begin{array}{l}\text { Heating } \\
\text { Penalty } \\
\text { (MMBtu) }\end{array}$ & $\begin{array}{l}\text { Lighting } \$ \\
\text { Saved }\end{array}$ & $\begin{array}{l}\text { Cooling } \$ \\
\text { Saved }\end{array}$ & $\begin{array}{c}\text { Heating \$ } \\
\text { Penally }\end{array}$ & $\begin{array}{c}\text { Maintenance \$ } \\
\text { Saved }\end{array}$ & Total \$ Saved & $\begin{array}{l}\text { Retrolit } \\
\text { Costs }\end{array}$ & $\begin{array}{l}\text { Payback } \\
\text { (years) }\end{array}$ \\
\hline 10 & FIRST FLOOA & 4.19 & 3.06 & 1.14 & 8,760 & 9,978 & 30.16 & 3.89 & $\$ 419$ & $\$ 132$ & $\$ 23$ & $\$ 1,107$ & $\$ 1,635$ & $\$ 2,409,94$ & 1.47 \\
\hline 10 & SECOND FLOOR & 7.77 & 5.17 & 2.60 & 8,760 & 22,794 & 68.89 & 8.88 & $\$ 957$ & $\$ 302$ & $\$ 52$ & $\$ 1,450$ & $\$ 2,657$ & $\$ 3,579.64$ & 1.35 \\
\hline 10 & THIRD FLOOR & 8.17 & 6.64 & 1.54 & 8,760 & 13,464 & 40.70 & 5.24 & $\$ 565$ & $\$ 178$ & $\$ 31$ & $\$ 1,467$ & $\$ 2,180$ & $\$ 3,913.25$ & 1.80 \\
\hline 10 & $A B / B B$ & 1.00 & 0.25 & 0.75 & 8,760 & 6.570 & 19.86 & 2.56 & $\$ 276$ & $\$ B 7$ & $\$ 15$ & $\$ 139$ & $\$ 487$ & 275.66 & 0.57 \\
\hline DTALS & & 21.14 & 15.11 & 6.03 & 8,760 & 52,805 & 159.60 & 20.57 & $\$ 2,218$ & $\$ 698$ & $\$ 121$ & $\$ 4,163$ & $\$ 6,959$ & $\$ 10,178,49$ & 1.46 \\
\hline
\end{tabular}

Advanced Retrofit

\begin{tabular}{|c|c|c|c|c|c|c|c|c|c|c|c|c|c|c|c|}
\hline BLDG & Floor & $\begin{array}{c}\text { Currently } \\
\text { Installed } \\
\mathrm{KW}\end{array}$ & Retrofit KW & $\begin{array}{c}\text { KW } \\
\text { Savings }\end{array}$ & $\begin{array}{c}\text { Hours } \\
\text { per year }\end{array}$ & $\begin{array}{c}\text { Lighting } \\
\text { KWH Saved }\end{array}$ & $\begin{array}{l}\text { Cooling } \\
\text { MMBtu } \\
\text { Saved }\end{array}$ & $\begin{array}{l}\text { Heating } \\
\text { Penalty } \\
\text { (MMBtu) }\end{array}$ & $\begin{array}{l}\text { Lighting \$ } \\
\text { Saved }\end{array}$ & $\begin{array}{c}\text { Cooling \$ } \\
\text { Saved }\end{array}$ & $\begin{array}{l}\text { Heating \$ } \\
\text { Penalty }\end{array}$ & $\begin{array}{c}\text { Maintenance \$ } \\
\text { Saved }\end{array}$ & Total \$ Saved & $\begin{array}{l}\text { Retrofit } \\
\text { Costs }\end{array}$ & $\begin{array}{l}\text { Payback } \\
\text { (years) }\end{array}$ \\
\hline 10 & FIRST FLOOR & 4.19 & 2.28 & 1.92 & 8,760 & 16,810 & 50.81 & 6.55 & $\$ 706$ & . $\$ 222$ & $\$ 39$ & $\$ 1,124$ & $\$ 2,014$ & $\$ 2,283.92$ & 1.13 \\
\hline 10 & SECOND FLOOR & 7.77 & 3.88 & 3.89 & 8,760 & 34,094 & 103.05 & 13.28 & $\$ 1,432$ & $\$ 451$ & $\$ 78$ & $\$ 1.476$ & $\$ 3,280$ & $\$ 3,600.57$ & 1.10 \\
\hline 10 & THIRD FLOOR & 8.17 & 4.18 & 4.00 & 8,760 & 35,014 & 105.83 & 13.64 & $\$ 1,471$ & $\$ 463$ & $\$ 80$ & $\$ 1,512$ & $\$ 3,366$ & $\$ 5,391.68$ & 1.60 \\
\hline 10 & $A B / B B$ & 1.00 & 0.25 & 0.75 & 8.760 & 6,570 & 19.86 & 2.56 & $\$ 276$ & 587 & $\$ 15$ & $\$ 139$ & $\$ 487$ & $\$ 275.66$ & 0.57 \\
\hline TOTALS & & 21.14 & 10.58 & 10.56 & 8,760 & 92,488 & 279.55 & 36.02 & $\$ 3,884$ & $\$ 1,223$ & $\$ 212$ & $\$ 4,250$ & $\$ 9,146$ & $\$ 11,551.84$ & 1.26 \\
\hline
\end{tabular}


TABLE A.12 Cost Savings from Using Retrofit Options at Building 11

\begin{tabular}{|c|c|c|c|c|c|c|c|c|c|c|c|c|c|c|c|}
\hline BLOG & Floor & $\begin{array}{c}\begin{array}{c}\text { Currently } \\
\text { Installed } \\
\mathrm{KW}\end{array} \\
\end{array}$ & Retrolit KW & $\begin{array}{c}\text { KW } \\
\text { Savings }\end{array}$ & $\begin{array}{c}\text { Hours } \\
\text { per year }\end{array}$ & $\begin{array}{c}\text { Lighling } \\
\text { KWH Saved }\end{array}$ & $\begin{array}{l}\text { Cooling } \\
\text { MMBtu } \\
\text { Saved } \\
\end{array}$ & \begin{tabular}{|c|} 
Heating \\
Penalty \\
(MMBiu)
\end{tabular} & $\begin{array}{l}\text { Lighting } \$ \\
\text { Saved }\end{array}$ & $\begin{array}{l}\text { Cooling \$ } \\
\text { Saved }\end{array}$ & $\begin{array}{l}\text { Heating \$ } \\
\text { Penalty }\end{array}$ & $\begin{array}{c}\text { Maintenance \$ } \\
\text { Saved }\end{array}$ & $\begin{array}{l}\text { Total \$ } \\
\text { Saved }\end{array}$ & $\begin{array}{l}\text { Retrofit } \\
\text { Costs }\end{array}$ & $\begin{array}{l}\text { Payback } \\
\text { (years) }\end{array}$ \\
\hline 11 & FIAST FLOOR & 16.64 & 15.08 & 1.56 & 8.760 & 13,666 & 41.30 & 5.32 & $\$ 574$ & $\$ 181$ & $\$ 31$ & $\$ 910$ & $\$ 1,633$ & $\$ 3,181$ & 1.95 \\
\hline 11 & SECOND FLOOR & 10.22 & 9.27 & 0.95 & 8,760 & 8,357 & 25.26 & 3.26 & $\$ 351$ & $\$ 111$ & $\$ 19$ & $\$ 557$ & $\$ 999$ & $\$ 1,945$ & 1.95 \\
\hline 11 & THIRD FLOOR & 12.08 & 10.64 & 1.44 & 8,760 & 12,614 & 38.13 & 4.91 & $\$ 530$ & $\$ 167$ & $\$ 29$ & $\$ 840$ & $\$ 1,508$ & $\$ 2,937$ & 1.95 \\
\hline 11 & $A B / B B$ & 0.90 & 0.90 & 0.00 & 8,760 & 0 & 0.00 & 0.00 & $\$ 0$ & so & $\$ 0$ & so & $\$ 0$ & $\$ 0$ & \\
\hline \multicolumn{2}{|l|}{5} & 39.84 & 35.89 & 3.95 & 8,760 & 34,637 & 104.69 & 13.49 & $\$ 1,455$ & $\$ 458$ & $\$ 79$ & $\$ 2,307$ & $\$ 4,140$ & $\$ 8,063$ & \\
\hline
\end{tabular}

\begin{tabular}{|c|c|c|c|c|c|c|c|c|c|c|c|c|c|c|c|}
\hline BLDG & Floor & \begin{tabular}{|c|}
$\begin{array}{c}\text { Currently } \\
\text { Installed } \\
\mathrm{KW}\end{array}$ \\
\end{tabular} & Retrofit KW & $\begin{array}{c}\mathrm{KW} \\
\text { Savings }\end{array}$ & $\begin{array}{l}\text { Hours } \\
\text { per year }\end{array}$ & $\begin{array}{c}\text { Lighting } \\
\text { KWH Saved }\end{array}$ & $\begin{array}{l}\text { Cooling } \\
\text { MMBtu } \\
\text { Saved }\end{array}$ & $\begin{array}{l}\text { Heating } \\
\text { Penalty } \\
\text { (MMBIu) } \\
\end{array}$ & $\begin{array}{l}\text { Lighting } \$ \\
\text { Saved }\end{array}$ & $\begin{array}{c}\text { Cooling } \$ \\
\text { Saved }\end{array}$ & $\begin{array}{l}\text { Heating } \$ \\
\text { Penalty }\end{array}$ & $\begin{array}{c}\text { Maintenance \$ } \\
\text { Saved }\end{array}$ & Total \$ Saved & $\begin{array}{l}\text { Retrofit } \\
\text { Costs }\end{array}$ & $\begin{array}{l}\text { Payback } \\
\text { (years) }\end{array}$ \\
\hline 11 & FIRST FLOOA & 16.64 & 12.06 & 4.58 & 8,760 & 40.121 & 121.27 & 15.63 & $\$ 1,685$ & $\$ 531$ & $\$ 92$ & $\$ 3,614$ & $\$ 5,737$ & $\$ 8,218$ & 1.43 \\
\hline 11 & SECOND FLOOR & 10.22 & 7.15 & 3.07 & 8,760 & 26,911 & 81.34 & 10.48 & $\$ 1,130$ & $\$ 356$ & $\$ 62$ & $\$ 2,135$ & $\$ 3,560$ & $\$ 6,536$ & 1.84 \\
\hline 11 & THIRD FLOOR & 12.08 & 9.86 & 2.22 & 8,760 & 19,447 & 58.78 & 7.57 & $\$ 817$ & $\$ 257$ & $\$ 45$ & $\$ 2,569$ & $\$ 3,598$ & $\$ 9,499$ & 2.64 \\
\hline 11. & AB/BB & 0.90 & 0.23 & 0.68 & 8,760 & 5,913 & 17.87 & 2.30 & $\$ 248$ & $\$ 78$ & $\$ 14$ & $\$ 125$ & $\$ 438$ & $\$ 248$ & 0.57 \\
\hline \multicolumn{2}{|c|}{ TOTALS } & 39.84 & 29.30 & 10.55 & 8,760 & 92,392 & 279.25 & 35.99 & $\$ 3,880$ & $\$ 1,222$ & $\$ 212$ & $\$ 8,442$ & $\$ 13,333$ & $\$ 24,501$ & 1.84 \\
\hline
\end{tabular}

\begin{tabular}{|c|c|c|c|c|c|c|c|c|c|c|c|c|c|c|c|}
\hline BLDG & Floor & $\begin{array}{c}\text { Currently } \\
\text { Installed } \\
\mathrm{KW}\end{array}$ & Retrofit KW & $\begin{array}{c}\text { KW } \\
\text { Savings }\end{array}$ & $\begin{array}{l}\text { Hours } \\
\text { per year }\end{array}$ & $\begin{array}{c}\text { Lighling } \\
\text { KWH Saved }\end{array}$ & $\begin{array}{l}\text { Cooling } \\
\text { MMBlu } \\
\text { Saved }\end{array}$ & $\begin{array}{c}\text { Heating } \\
\text { Penalty } \\
\text { (MMBlu) }\end{array}$ & $\begin{array}{l}\text { Lighting \$ } \\
\text { Saved }\end{array}$ & $\begin{array}{l}\text { Cooling \$ } \\
\text { Saved }\end{array}$ & $\begin{array}{l}\text { Heating \$ } \\
\text { Penalty }\end{array}$ & $\begin{array}{c}\text { Maintenance \$ } \\
\text { Saved }\end{array}$ & Total \$ Saved & $\begin{array}{l}\text { Retrofit } \\
\text { Costs }\end{array}$ & $\begin{array}{l}\text { Payback } \\
\text { (years) }\end{array}$ \\
\hline 11 & FIRST FLOOR & 16.64 & 9.44 & 7.20 & 8,760 & 63,072 & 190.64 & 24.57 & $\$ 2,649$ & $\$ 834$ & $\$ 145$ & $\$ 3,596$ & $\$ 6,935$ & $\$ 10,590$ & 1.53 \\
\hline 11 & SECOND FLOOR & 10.22 & 4.96 & 5.26 & 8,760 & 46,095 & 139.32 & 17.95 & $\$ 1,936$ & $\$ 610$ & $\$ 106$ & $\$ 2,172$ & $\$ 4,612$ & $\$ 6,365$ & 1.38 \\
\hline 11 & THIRD FLOOR & 12.08 & 6.41 & 5.67 & 8,760 & 49,669 & 150.13 & 19.35 & $\$ 2,086$ & $\$ 657$ & $\$ 114$ & $\$ 2,628$ & $\$ 5,257$ & $\$ 9,189$ & 1.75 \\
\hline 11 & $A B / B B$ & 0.90 & 0.23 & 0.68 & 8,760 & 5,913 & 17.87 & 2.30 & $\$ 248$ & $\$ 78$ & $\$ 14$ & $\$ 125$ & $\$ 438$ & $\$ 248$ & 0.57 \\
\hline TOTALS & & 39.84 & 21.04 & 18.81 & 8,760 & 164,749 & 497.96 & 64.17 & $\$ 6,919$ & $\$ 2,179$ & $\$ 377$ & $\$ 8,521$ & $\$ 17,242$ & $\$ 26,392$ & 1.53 \\
\hline
\end{tabular}


TABLE A.13 Cost Savings from Using Retrofit Options at Building 101

\begin{tabular}{|c|c|c|c|c|c|c|c|c|c|c|c|c|c|c|c|}
\hline BLOG & Floor & $\begin{array}{c}\text { Currently } \\
\text { Installed } \\
\mathrm{KW}\end{array}$ & Retrofit KW & $\begin{array}{c}\mathrm{KW} \\
\text { Savings }\end{array}$ & $\begin{array}{c}\text { Hours } \\
\text { per year }\end{array}$ & $\begin{array}{l}\text { Lighting } \\
\text { KWH Saved }\end{array}$ & $\begin{array}{l}\text { Cooling } \\
\text { MMBtu } \\
\text { Saved }\end{array}$ & $\begin{array}{l}\text { Reating } \\
\text { Penalty } \\
\text { (MMBtu) }\end{array}$ & $\begin{array}{l}\text { Lighting } \$ \\
\text { Saved }\end{array}$ & $\begin{array}{l}\text { Cooling \$ } \\
\text { Saved }\end{array}$ & $\begin{array}{l}\text { Heating \$ } \\
\text { Penalty }\end{array}$ & $\begin{array}{c}\text { Maintenance } \\
\text { \$ Saved }\end{array}$ & $\begin{array}{l}\text { Total \$ } \\
\text { Saved }\end{array}$ & Retrofit Costs & $\begin{array}{l}\text { Payback } \\
\text { (years) }\end{array}$ \\
\hline $\begin{array}{l}101 \\
101\end{array}$ & $\begin{array}{l}\text { FIRST FLOOR } \\
\text { SECONO FLOOR }\end{array}$ & $\begin{array}{l}24.78 \\
23.30\end{array}$ & $\begin{array}{r}22.10 \\
20.59\end{array}$ & $\begin{array}{l}2.68 \\
2.71\end{array}$ & $\begin{array}{l}8,760 \\
8,760\end{array}$ & $\begin{array}{l}23,494 \\
23,705\end{array}$ & $\begin{array}{l}71.01 \\
71.65\end{array}$ & $\begin{array}{l}9.15 \\
9.23\end{array}$ & $\begin{array}{l}\$ 987 \\
\$ 996\end{array}$ & $\begin{array}{l}\$ 311 \\
\$ 314\end{array}$ & $\begin{array}{l}\$ 54 \\
\$ 54\end{array}$ & $\begin{array}{l}\$ 1,565 \\
\$ 1,579\end{array}$ & $\begin{array}{l}\$ 2,808 \\
\$ 2,833\end{array}$ & $\begin{array}{l}\$ 5,348 \\
\$ 5,396\end{array}$ & $\begin{array}{l}1.90 \\
1.90\end{array}$ \\
\hline TOTALS & & 48.08 & 42,69 & 5.39 & 8,760 & 47.199 & 142.66 & 18.38 & $\$ 1,982$ & $\$ 624$ & $\$ 108$ & $\$ 3,143$ & $\$ 5,642$ & $\$ 10,744$ & 1.90 \\
\hline
\end{tabular}

\begin{tabular}{|c|c|c|c|c|c|c|c|c|c|c|c|c|c|c|c|}
\hline$B L D G$ & Floor & $\begin{array}{c}\text { Currently } \\
\text { Installed } \\
\mathrm{KW}\end{array}$ & Retrofit KW & $\begin{array}{c}\mathrm{KW} \\
\text { Savings }\end{array}$ & $\begin{array}{c}\text { Mours } \\
\text { per year }\end{array}$ & $\begin{array}{c}\text { Lighting } \\
\text { KWH Savad }\end{array}$ & $\begin{array}{l}\text { Cooling } \\
\text { MMBtu } \\
\text { Saved }\end{array}$ & $\begin{array}{c}\text { Healing } \\
\text { Penalty } \\
\text { (MMBtu) }\end{array}$ & $\begin{array}{l}\text { Lighting \$ } \\
\text { Saved }\end{array}$ & $\begin{array}{l}\text { Cooling \$ } \\
\text { Savod }\end{array}$ & $\begin{array}{c}\text { Heating } \$ \\
\text { Penally }\end{array}$ & $\begin{array}{l}\text { Maintenance } \\
\text { \$ Saved }\end{array}$ & Total \$ Saved & Retrofit Costs & $\begin{array}{l}\text { Payback } \\
\text { (years) }\end{array}$ \\
\hline $\begin{array}{l}101 \\
101\end{array}$ & $\begin{array}{l}\text { FIRST FLOOR } \\
\text { SECOND FLOOR }\end{array}$ & $\begin{array}{l}24.78 \\
23.30\end{array}$ & $\begin{array}{r}19.48 \\
18.94\end{array}$ & $\begin{array}{l}5.30 \\
4.36\end{array}$ & $\begin{array}{l}8.760 \\
8,760\end{array}$ & $\begin{array}{r}46.437 \\
38,176\end{array}$ & $\begin{array}{l}140.36 \\
115.39\end{array}$ & $\begin{array}{l}18.09 \\
14.87\end{array}$ & $\begin{array}{l}\$ 1,950 \\
\$ 1,603\end{array}$ & $\begin{array}{r}\$ 614 \\
\$ 505\end{array}$ & $\begin{array}{r}\$ 106 \\
\$ 87\end{array}$ & $\begin{array}{l}\$ 5,297 \\
\$ 4,778\end{array}$ & $\begin{array}{r}\$ 7.756 \\
\$ 6.798\end{array}$ & $\begin{array}{l}\$ 5,651 \\
\$ 5,516\end{array}$ & $\begin{array}{l}0.73 \\
0.81\end{array}$ \\
\hline$\overline{\text { TOTALS }}$ & & 48.08 & 38.42 & 9.66 & 8,760 & 84,613 & 255.74 & 32.96 & $\$ 3,554$ & $\$ 1,119$ & $\$ 194$ & $\$ 10,075$ & $\$ 14,554$ & $\$ 11,167$ & $\overline{0.77}$ \\
\hline
\end{tabular}

\begin{tabular}{|c|c|c|c|c|c|c|c|c|c|c|c|c|c|c|c|}
\hline BLDG & Floor & $\begin{array}{c}\text { Currently } \\
\text { Installed } \\
\mathrm{KW}\end{array}$ & Retrofit KW & $\begin{array}{c}\mathrm{KW} \\
\text { Savings }\end{array}$ & $\begin{array}{c}\text { Mours } \\
\text { per year }\end{array}$ & $\begin{array}{c}\text { Lighting } \\
\text { KWH Saved }\end{array}$ & $\begin{array}{l}\text { Cooling } \\
\text { MMBtu } \\
\text { Saved } \\
\end{array}$ & $\begin{array}{c}\text { Hoating } \\
\text { Penalty } \\
\text { (MMBtu) }\end{array}$ & $\begin{array}{l}\text { Lighting \$ } \\
\text { Saved }\end{array}$ & $\begin{array}{c}\text { Cooling } \$ \\
\text { Saved }\end{array}$ & $\begin{array}{l}\text { Heating \$ } \\
\text { Penally }\end{array}$ & $\begin{array}{c}\text { Maintenance } \\
\$ \text { Saved }\end{array}$ & Total \$ Saved & Retrofit Costs & $\begin{array}{l}\text { Payback } \\
\text { (years) }\end{array}$ \\
\hline 101 & FIRST FLOOR & 24.78 & 14.69 & 10.10 & 8,760 & 88,441 & 267.31 & 34.45 & $\$ 3,715$ & $\$ 1,170$ & $\$ 203$ & $\$ 5,311$ & $\$ 9,992$ & $\$ 16,915$ & 1.69 \\
\hline 101 & SECOND FLOOR & 23.30 & 14.80 & 8.50 & 8,760 & 74,442 & 225.00 & 29.00 & $\$ 3.127$ & $\$ 985$ & $\$ 171$ & $\$ 4,744$ & $\$ 8,684$ & $\$ 17,233$ & 1.98 \\
\hline
\end{tabular}


TABLE A.14 Cost Savings from Using Retrofit Options at Building 617

\begin{tabular}{|c|c|c|c|c|c|c|c|c|c|c|c|c|c|c|c|}
\hline BLDG & Floor & $\begin{array}{c}\text { Currently } \\
\text { installed } \\
\mathrm{kW}\end{array}$ & Retrofit kW & $\begin{array}{c}\mathrm{kW} \\
\text { Savings }\end{array}$ & $\begin{array}{c}\text { Hours } \\
\text { per year }\end{array}$ & $\begin{array}{l}\text { Lighting } \\
\text { kWh Saved }\end{array}$ & $\begin{array}{l}\text { Cooling } \\
\text { MMBtu } \\
\text { Saved }\end{array}$ & \begin{tabular}{|c|} 
Heating \\
Penalty \\
(MMBtu)
\end{tabular} & $\begin{array}{l}\text { Lighting \$ } \\
\text { Saved }\end{array}$ & $\begin{array}{l}\text { Cooling \$ } \\
\text { Saved }\end{array}$ & $\begin{array}{l}\text { Heating \$ } \\
\text { Ponalty }\end{array}$ & $\begin{array}{c}\text { Maintenance } \\
\$ \text { Saved }\end{array}$ & $\begin{array}{l}\text { Total \$ } \\
\text { Saved }\end{array}$ & Retrofit Costs & $\begin{array}{l}\text { Payback } \\
\text { (years) }\end{array}$ \\
\hline 617 & FIAST FLOO & 6.50 & 6.34 & 0.16 & 8,760 & 1,367 & 4.13 & 0.53 & $\$ 57$ & $\$ 18$ & $\$ 3$ & $\$ 91$ & $\$ 166$ & $\$ 311$ & 1.90 \\
\hline OTALS & & 6.50 & 6.34 & 0.16 & 8,760 & 1,367 & 4.13 & 0.53 & $\$ 57$ & $\$ 18$ & $\$ 3$ & $\$ 91$ & $\$ 163$ & $\$ 311$ & $\frac{1.90}{1.9000}$ \\
\hline
\end{tabular}

\begin{tabular}{|c|c|c|c|c|c|c|c|c|c|c|c|c|c|c|c|}
\hline BLDG & Floor & $\begin{array}{c}\begin{array}{c}\text { Currently } \\
\text { Installed } \\
\mathrm{kW}\end{array} \\
\end{array}$ & Retrofit kW & $\begin{array}{c}k W \\
\text { Savings }\end{array}$ & $\begin{array}{c}\text { Hours } \\
\text { per year }\end{array}$ & $\begin{array}{c}\text { Lighting kWh } \\
\text { Saved }\end{array}$ & $\begin{array}{l}\text { Cooling } \\
\text { MMBtu } \\
\text { Saved }\end{array}$ & $\begin{array}{l}\text { Heating } \\
\text { Penalty } \\
\text { (MMBtu) }\end{array}$ & $\begin{array}{l}\text { Lighting \$ } \\
\text { Saved }\end{array}$ & $\begin{array}{c}\text { Cooling } \$ \\
\text { Saved }\end{array}$ & $\begin{array}{c}\text { Heating \$ } \\
\text { Penally }\end{array}$ & $\begin{array}{c}\text { Maintenance } \\
\text { \$ Saved }\end{array}$ & Total \$ Saved & Retrofit Costs & $\begin{array}{l}\text { Payback } \\
\text { (years) }\end{array}$ \\
\hline 617 & FIRST FLOO & 6.50 & 6.07 & 0.43 & 8,760 & 3,793 & 11.46 & 1.48 & $\$ 159$ & $\$ 50$ & $\$ 9$ & $\$ 430$ & $\$ 631$ & $\$ 331$ & 0.52 \\
\hline TOTALS & & 6.50 & 6.07 & 0.43 & 8,760 & 3,793 & 71.46 & 1.48 & $\$ 159$ & $\$ 50$ & $\$ 9$ & $\$ 430$ & $\$ 631$ & $\$ 331$ & 0.52 \\
\hline
\end{tabular}

\begin{tabular}{|c|c|c|c|c|c|c|c|c|c|c|c|c|c|c|c|}
\hline BLDG & Floor & \begin{tabular}{|c|}
$\begin{array}{c}\text { Currently } \\
\text { Installed } \\
\mathrm{kW}\end{array}$ \\
\end{tabular} & Rotrofit kW & $\begin{array}{c}\mathrm{kW} \\
\text { Savings }\end{array}$ & $\begin{array}{c}\text { Hours } \\
\text { per year }\end{array}$ & $\begin{array}{c}\text { Lighting kWh } \\
\text { Saved }\end{array}$ & $\begin{array}{l}\text { Cooling } \\
\text { MMBtu } \\
\text { Saved }\end{array}$ & \begin{tabular}{|c|} 
Heating \\
Penalty \\
(MMBiu) \\
\end{tabular} & $\begin{array}{l}\text { Lighting \$ } \\
\text { Saved }\end{array}$ & $\begin{array}{c}\text { Cooling } \$ \\
\text { Saved }\end{array}$ & $\begin{array}{c}\text { Heating } \$ \\
\text { Penally }\end{array}$ & $\begin{array}{c}\text { Maintenance } \\
\text { \$ Saved }\end{array}$ & Total \$ Saved & Retrofit Costs & $\begin{array}{l}\text { Payback } \\
\text { (years) }\end{array}$ \\
\hline 617 & FIRST FLOOF & 6.50 & 5.68 & 0.82 & 8,760 & 7,209 & 21.79 & 2.81 & $\$ 303$ & $\$ 95$ & $\$ 17$ & $\$ 433$ & $\$ 815$ & $\$ 982$ & 1.21 \\
\hline TOTALS & & 6.50 & 5.68 & 0.82 & 8,760 & 7,209 & 21.79 & 2.81 & $\$ 303$ & $\$ 95$ & $\$ 17$ & $\$ 433$ & $\$ 815$ & $\$ 982$ & 1.21 \\
\hline
\end{tabular}


TABLE A.15 Cost Components

Retrofit Description

Estimated Total Costs

\begin{tabular}{|c|c|c|c|c|}
\hline & $\begin{array}{c}\text { \# of } \\
\text { Lamps }\end{array}$ & $\begin{array}{c}\text { Total } \\
\text { Costs } \\
\text { Outside }\end{array}$ & $\begin{array}{l}\text { Total } \\
\text { Costs } \\
\text { Inside }\end{array}$ & $\begin{array}{c}\text { Maintenance } \\
\text { \$ Saved }\end{array}$ \\
\hline \multirow[t]{4}{*}{ Replace existing T-12s with 34 watt, T-12s } & 1 & $\$ 11.96$ & $\$ 12.24$ & 3.50 \\
\hline & 2 & $\$ 23.93$ & $\$ 24.47$ & 7.00 \\
\hline & 3 & $\$ 35.89$ & $\$ 36.71$ & 10.50 \\
\hline & 4 & $\$ 47.86$ & $\$ 48.94$ & 14.00 \\
\hline Replace existing T-12s with 32 watt, $T-8$ with electronic ballast & 1 & $\$ 66.63$ & $\$ 70.30$ & 12.75 \\
\hline \multirow[t]{3}{*}{ Assume one new ballast per installation } & 2 & $\$ 73.04$ & $\$ 76.97$ & 20.00 \\
\hline & 3 & $\$ 79.44$ & $\$ 83.65$ & 27.25 \\
\hline & 4 & $\$ 85.85$ & $\$ 90.32$ & 34.50 \\
\hline Replace entire $T-12$ fixture with new $T-8$ fixture & 1 & $\$ 54.43$. & $\$ 57.82$ & 12.75 \\
\hline $1 \times 4$ & & & & 22.60 \\
\hline Replace entire $T-12$ fixture with new T-8 fixture, $2 \times 4,2$ lamps & 2 & $\$ 91.64$ & $\$ 96.73$ & 29.90 \\
\hline Replace existing Incandescent with Compact Fluorescent & 1 & $\$ 27.29$ & $\$ 27.57$ & 13.90 \\
\hline Replace existing Incandescent with 75 Watt PAR-38 Flood & 1 & $\$ \quad 6.58$ & $\$ 6.86$ & 56.70 \\
\hline Install Fluorescent Task Light & 1 & $\$ 25.57$ & $\$ 26.08$ & -5.00 \\
\hline Install Light Control System & 1 & $\$ 177.81$ & $\$ 189.34$ & -15.78 \\
\hline
\end{tabular}


APPENDIX B:

FLUOREŚCENT LAMP AND BALLAST RECYCLERS 
TABLE B.1 Fluorescent Lamp and Ballast Recyclers

\begin{tabular}{ccc} 
& & \\
Name & Contact Information & Services Offered \\
\hline
\end{tabular}

Lighting Resources, Inc.

Lighting Resources, Inc.

Attn: John Chilcott

Mercury Recovery Services

Mercury Technologies International

Salesco U.S.A.
1522 East Victory Street

Suite 2

Phoenix, AZ 85040

(602) $276-4278$ or $(800)$ 641-9253

Fax: (602) 276-5432

386 South Gordan Street

Pomona, CA 91766

(714) 622-0881 or (800) 572-9253

2021 South Myrtle Avenue

Monrovia, CA 91016

(818) $301-1372$

30677 Huntwood Avenue

Hayward, CA 94544

(800) 628-3675

Fax: (510) 429-1498

9520 Jefferson Boulevard

Culver City, CA 90232

(310) 836-4MTI

Fax: (210) 836-3342

674 Via De La Valle

Suite 203

Solona Beach, CA 92075

(619) 793-3460
Fluorescent lamps and ballasts

Fluorescent lamps

Fluorescent and HID lamps

Fluorescent and HID lamps

Southern California service center for fluorescent and HID lamps

Fluorescent lamps and ballasts and other PCBcontaminated material 
TABLE B.1 (Cont.)

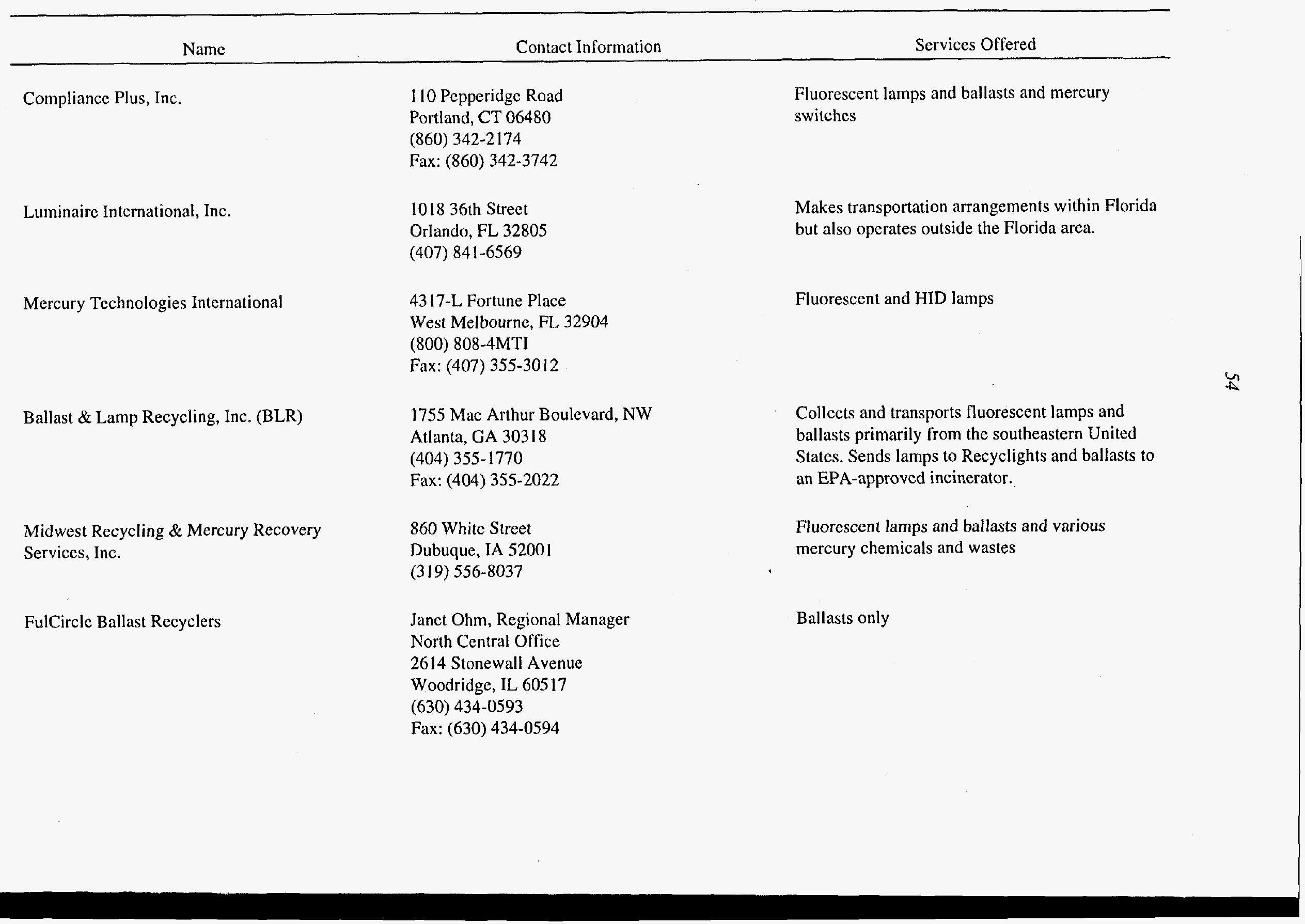


TABLE B.1 (Cont.)

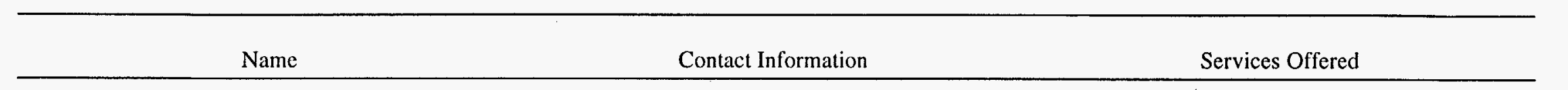

Salesco U.S.A.

Ballast and Lamp Recycling, Inc. (BLR)

Lighting Resources, Inc.

Lighting Resources, Inc.

Lamp Recyclers of Louisiana, Inc.

Alta Resources Management Services
3800 North Wilke Road

Suite 300

Arlington Heights, IL 60004-1267

(708) 259-8311 or (800) 881-6811

1002 West Troy Avenue

Indianapolis, IN 46225

(317) $782-3228$

5172 East 65 th Street

Indianapolis, IN 46220

(317) $577-9100$ or (800) 466-9106

Fax: (317) 577-9161

498 Park 800 Drive

Greenwood, IN 46143

(317) $888-3889$ or (800) $572-9253$

46257 Morris Road

P.O. Box 2962

Hammond, LA 70404-2962

(504) 345-4147 or (800) 309-9908

Fax: (504) $345-4775$

88-B Industry Avenue

Springfield, MA 00104-9926

(413) 734-3399
Fluorescent lamps and ballasts and other PCBcontaminated material

Fluorescent lamps and ballasts

Fluorescent lamps and ballasts. Has mercury retort facility.

Fluorescent lamps and ballasts

Transports and recycles fluorescent and HID lamps. Transports and disposes of PCB and nonPCB ballasts.

Fluorescent lamps and ballasts 
TABLE B.1 (Cont.)

\begin{tabular}{|c|c|c|}
\hline Name & Contact Information & Services Offered \\
\hline Ensquare, Inc. & $\begin{array}{l}\text { P.O. Box } 1056 \\
\text { Brookline, MA } 02146 \\
(617) 776-7320 \\
(612) 828-9722\end{array}$ & Ballasts only \\
\hline Global Recycling Technologies & $\begin{array}{l}\text { P.O. Box } 651 \\
\text { Stoughton, MA } 02072 \\
\text { (617) } 341-6080\end{array}$ & Fluorescent lamps, ballasts, and dry-cell batteries \\
\hline Salesco, U.S.A. & $\begin{array}{l}387 \text { Page Street } \\
\text { Stoughton, MA } 02072 \\
(617) 344-4074\end{array}$ & Ballasts only \\
\hline FulCircle Ballast Recyclers & $\begin{array}{l}\text { Ron Waxell } \\
1223 \text { Clopton Bridge } \\
\text { Rochester Hills, MI } 48306 \\
\text { (810) } 651-6589 \text { or }(800) 775-1516\end{array}$ & Ballasts only \\
\hline Dynex & $\begin{array}{l}23460 \text { Industrial Park Drive } \\
\text { Farmington Hills, MI } 48335 \\
(800) 733-9639\end{array}$ & Ballasts only \\
\hline Aagard Environmental Services & $\begin{array}{l}3291 \text { Terminal Drive } \\
\text { Egan, MN 55121 } \\
\text { (612) } 686-2371\end{array}$ & $\begin{array}{l}\text { Transports fluorescent lamps and ballasts for } \\
\text { Recyclights. }\end{array}$ \\
\hline Dynex & $\begin{array}{l}\text { 4751 Mustang Circle } \\
\text { St. Paul, MN 55112 } \\
\text { (800) } 733-9639\end{array}$ & Fluorescent lamps and ballasts \\
\hline
\end{tabular}


TABLE B.1 (Cont.)

\begin{tabular}{ccc}
\hline Name & Contact Information \\
\hline
\end{tabular}

Light Cycle, Inc.

Luminaire Recycling, Inc.

Mercury Technologies of MN

Recyclights

Retrofit Recycling, Inc.

USA Lights
1222 University Avenue

St. Paul, MN 55104

(612) 649-1309

2161 University Avenue

Suite 206

St. Paul, MN 55114

(612) 649-0079

P.O. Box 13

Pine City Industrial Park

Pine City, MN 55063-0013

(612) 629-7888

401 West 86th Street

Minneapolis, MN 55420

(612) 948-0626 or (800) 831-2852

Fax: (612) 948-0627

RR 1, Box 41B

Owatonna, MN 55060

(800) $795-1230$

Fax: (507) 455-2192

2007 County Road C-2

Roseville, MN 55113

(612) 628-9370
Fluorescent lamps and ballasts. Makes shipping arrangements.

Fluorescent lamps and ballasts, mercury switches, batteries (including $\mathrm{Ni}-\mathrm{Cad}$ ), and various mercury-containing chemicals

Fluorescent lamps

Fluorescent lamps, mercury-containing devices, and dental amalgam

Transports fluorescent lamps for Recyclights and offers fluorescent lamp consultation service in Midwestern counties

Fluorescent lamps 
TABLE B.1 (Cont.)

Name Contact Information $\quad$ Services Offered

Environmental Management Solutions, Inc.

P.O. Box 6434

High Point, NC 27262

(910) $869-8836$

Fax: (910) 869-8704

Transformer Service, Inc.

Mercury Refining Company

FulCircle Ballast Recyclers

Eastern Environmental

American Recycling Co., Ltd.

74 Regional Drive
Concord, NH 03301

(603) 224-4006

1218 Central Avenue

Albany, NY 12205

(518) 459-3505 or (800) 833-3505

Headquarters

509 Manida Street

Bronx, NY 10474

(800) 581-0857

Fax: (718) 542-5335

473 Purdy

Port Chester, NY 10573

(800) 808-PCBS or (914) 934-2100

Fax: (914) 934-9649

7471 Tyler Boulevard

Mentor, OH 44060

(216) $946-2221$

Fax: (216) 946-0045
Fluorescent lamps and ballasts

Ballasts only

Fluorescent lamps, mercury button batteries, mercury switches

Ballasts only

Ballast and fluorescent lamp recycling and transformer disposal.

Fluorescent lamps and ballasts 
TABLE B.1 (Cont.)

\begin{tabular}{rlrl}
\hline Name & Contact Information & Services Offered \\
\hline
\end{tabular}

Clean Harbors Customer Service

Dlubaks Glass Co.

Environmental Recycling

I.G., Inc.

LIGHTSOUT, Inc.

S.D. Myers
4879 Spring Grove Avenue

Cincinnati, OH 45232

(513) 681-5738

Fax: (513) 681-6246

11567 County Highway 110 Upper Sandusky, OH 43351

(419) 294-4466

5265 Tractor Road

Suite B

Toledo, $\mathrm{OH} 43612$

(419) 269-1493

Fax: (419) 269-1594

3476 Saint Rocco Court

Cleveland, $\mathrm{OH} 44109$

(216) 631-7710

Fax: (216) 631-7711

2301 Hamilton Avenue

Cleveland, $\mathrm{OH} 44114$

(216) $621-6367$

Fax: (216) 621-7908

180 South Avenue

Tallmage, OH 44278

(216) 633-2666, ext. 3344

Fax: (216) 633-6615
Transports lamps or lamp components to a lamp retort or lamp recycling facility. Stabilizes lamps and delivers them to either a solid waste or hazardous waste landfill.

Fluorescent and incandescent lamps and other glass materials

Fluorescent lamps and nonleaking ballasts

Fluorescent lamps, computer monitors, and televisions

Collects and consolidates lamps for USA Lights and Ballasts Recycling, and ballasts for Full Circle Ballast Recyclers.

Ballasts only 
TABLE B.1 (Cont.)

\begin{tabular}{|c|c|c|}
\hline Name & Contact Information & Services Offered \\
\hline Sunpro & $\begin{array}{l}7392 \text { Whipple Avenue, NW } \\
\text { North Canton, OH } 44720 \\
\text { (216) } 966-0910 \\
\text { Fax: (216) } 966-1954\end{array}$ & $\begin{array}{l}\text { Brokers fluorescent lamps and ballasts for } \\
\text { industry and electrical equipment companies }\end{array}$ \\
\hline USA Lamp and Ballast Recycling & $\begin{array}{l}\text { 5366 Este Avenue } \\
\text { Cincinnati, OH } 45232 \\
(800) 778-6645 \\
\text { Fax: (606) 689-4594 }\end{array}$ & Fluorescent and incandescent lamps and ballasts \\
\hline Advanced Environmental Recycling Corporation & $\begin{array}{l}2591 \text { Mitchell Avenue } \\
\text { Allentown, PA } 18103 \\
(800) \text { 554-AERC } \\
\text { Fax: }(610) 797-7696\end{array}$ & $\begin{array}{l}\text { Mercury devices, compounds and solutions, } \\
\text { fluorescent and HID lamps, precious metals }\end{array}$ \\
\hline American Waste Management, Inc. & $\begin{array}{l}\text { P.O. Box } 454 \\
948 \text { 5th Avenue } \\
\text { Coraopolis, PA } 15108 \\
\text { (412) 262-0702 } \\
\text { Fax: (412) 262-0701 }\end{array}$ & Fluorescent and HID lamps and ballasts \\
\hline Bethlehem Apparatus Co., Inc. & $\begin{array}{l}890 \text { Front Street } \\
\text { Hellertown, PA } 18055 \\
(610) \text { 838-0701 }\end{array}$ & $\begin{array}{l}\text { Mercury lamps, mercury-containing } \\
\text { thermometers, switches, batteries, and dental } \\
\text { amalgam }\end{array}$ \\
\hline Dlubak's Glass Co. & $\begin{array}{l}\text { R.D. 1-274 } \\
\text { Saxonburg Road } \\
\text { Natrona Heights, PA } 15065 \\
(412) 224-6611\end{array}$ & $\begin{array}{l}\text { Glass materials, including fluorescent and } \\
\text { incandescent lamps, CRTs, halogen lamps, and } \\
\text { windshield glass }\end{array}$ \\
\hline
\end{tabular}




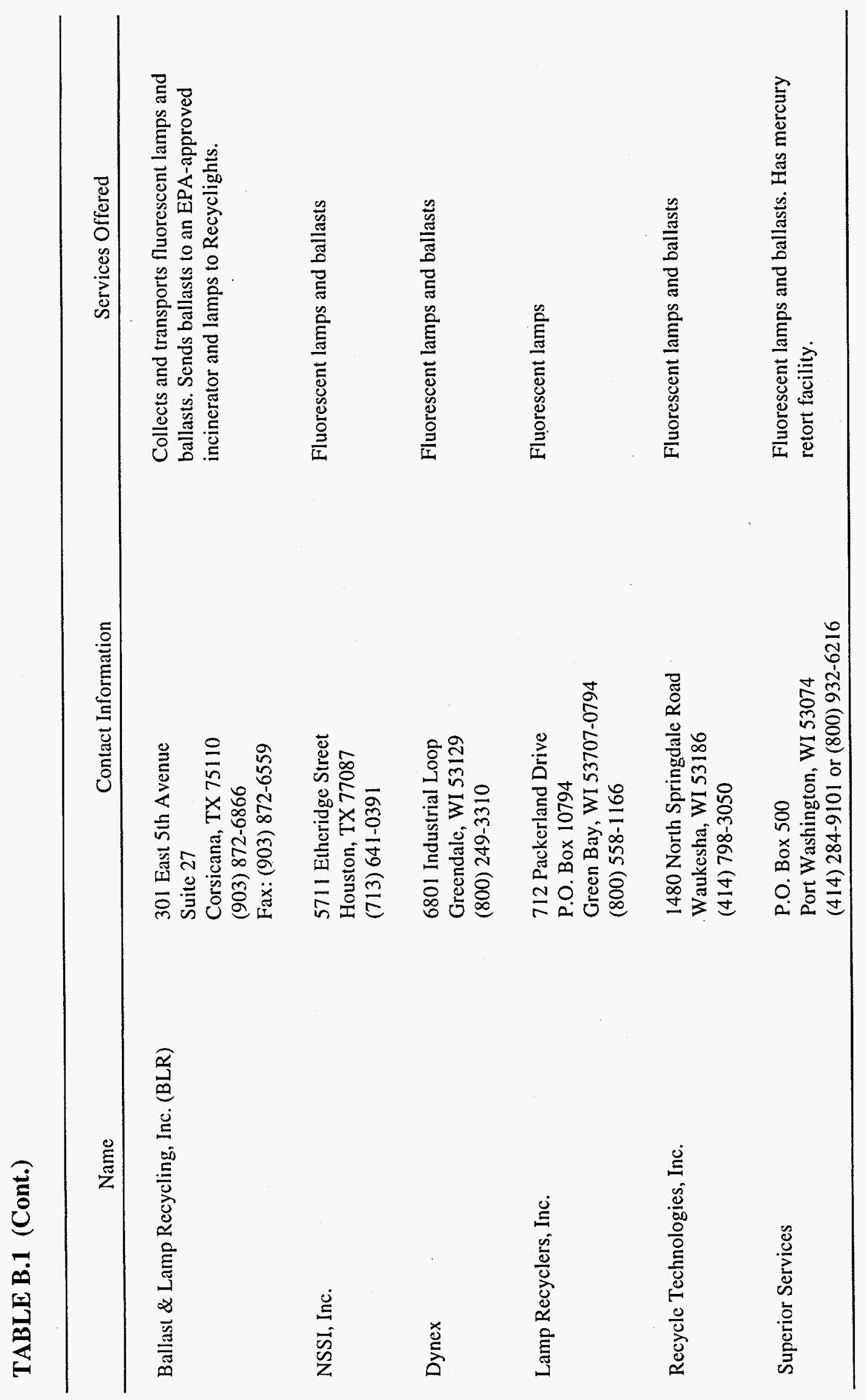




\section{APPENDIX C:}

EPA INFORMATION ON FLUORESCENT LAMP DISPOSAL 


\section{LIGHTING WASTE DISPOSAL}

March 1995

Upgrading a lighting system will likely involve the removal and disposal of lamps and ballasts. Some of this waste may be hazardous, and you must manage it accordingly. This document provides an overview of issues relating to the disposal of lamps and ballasts. For project-specific assistance, please refer to the information resources provided at the end of this document.

Note: The information in this document is believed to be correct as of March 1995. EPA does not provide legal advice, nor does this document. Generators of lighting wastes should check with local, state and regional authorities for the most up-to-date information.

DISPOSAL OF PCBCONTAINING BALLASTS

\section{CONTENTS}

ACTION CHECKLISTS 1

PCB-CONTAINING BALLASTS 2

DEHP-CONTAINING BALLASTS .7

MERCURY-CONTAINING LAMPS. .7

EVALUATING DISPOSAL OPTIONS 11

WORKING WITH CONTRACTORS 13

DEFINITIONS. 13

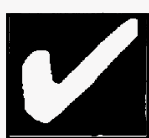

\section{ACTION CHECKLIST}

$\checkmark \quad$ Investigate and follow state and local requirements for handling and disposing of ballasts.

$\checkmark$ Identify ballasts that contain PCBs and ballasts that are leaking PCBs.

$\checkmark$ Remove, handle, and dispose of leaking PCBcontaining ballasts by high-temperature incineration.

$\checkmark$ Green Lights recommends disposing of nonleaking PCB-containing ballasts in an environmentally responsible manner, such as by high-temperature incineration, recycling, or chemical or hazardous waste landfill.

$\checkmark$ Maintain permanent records of PCB-containing ballast disposal.

\section{DISPOSAL OF MERCURY- CONTAINING LAMPS

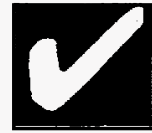 \\ ACTION CHECKLIST}

$\checkmark \quad$ Investigate and follow state and local requirements for handling and disposing of lamps.

$\checkmark$ If you have not tested your mercury-containing lamp wastes to show that they are not hazardous, then assume they are hazardous and dispose of them as hazardous waste

$\checkmark$ Mercury-containing lamps that test hazardous must be handled in compliance with hazardous waste regulations.

$\checkmark$ Maintain permanent records of mercury-containing lamps that are disposed as hazardous waste. 


\section{PCB-CONTAINING BALLASTS}

The primary concem regarding the disposal of used fluorescent ballasts is the health risk associated with polychlorinated biphenyls (PCBs). Human exposure to these possible carcinogens can cause skin, liver, and reproductive disorders. Fluorescent and highintensity discharge (HID) ballasts contain a small capacitor that may contain high concentrations of PCBs (greater than $90 \%$ pure PCBs or $900,000 \mathrm{ppm}$ ). These chemical compounds were widely used as insulators in electrical equipment such as capacitors, switches, and voltage regulators through the late 1970 s.

The Toxic Substances Control Act (TSCA) was enacted in 1976, and subsequently banned the production of PCBs in the United States. The specific regulations goveming the use and disposal of PCBs are found in Volume 40 Code of Federal Regulations (CFR) Part 761.

The proper method for disposing used ballasts depends on several factors, such as the type and condition of the ballasts and the regulations or recommendations in effect in the state(s) where you remove or discard them. TSCA specifies the disposa! method for ballasts that are leaking PCBs. In addition, generators of PCB-containing ballast wastes may be subject to notification and liability provisions under the Comprehensive Environmental Response,

Compensation and Liability Act of 1980 (CERCLA) also known as "Superfund." To select the appropriate disposal method for $\mathrm{PCB}$-containing ballasts, refer to the decision flow chart on the following page.

Because disposal requirements vary from state to state, check with regional, state, or local authorities for all applicable regulations in your area. For your convenience, information resources are listed at the end of this document.

\section{Identifying PCB Ballasts}

Use the following guidelines to identify ballasts that contain PCBs.

- All ballasts manufactured through 1979 contain PCBs.

- Ballasts manutactured after 1979 that do not contain PCBs are labeled "No PCBs."

- If a ballast is not labeled "No PCBs," assume it contains PCBs.
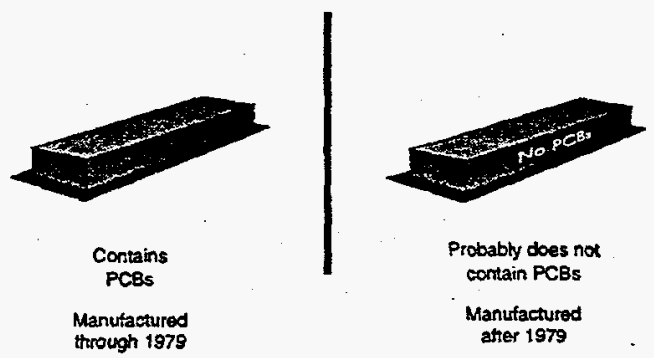

It is extremely important to find out if a ballast containing PCBs is leaking before you remove it from the fixture, so that you can handle it properly.

\section{Federal Requirements}

\section{Non-Leaking PCB Ballast Disposal}

TSCA regulates ballasts that contain PCBs (40 CFR $761.60(\mathrm{~b})(2)(i i))$. Under TSCA, intact fluorescent and HID ballasts that are not leaking PCBs may be disposed in a municipal solid waste landfill. EPA recommends packing and sealing the intact ballasts in 55 gailon drums. Green Lights also encourages its participants to dispose of PCB-containing ballast wastes responsibly, and recommends high-temperature incineration, recycling, or a chemical or hazardous waste landfill.

In addition, CERCLA regulates the disposal of nonleaking $\mathrm{PCB}$-containing ballasts. CERCLA requires building owners and waste generators to notify the National Response Center at (800) 424-8802. They must notify when disposing a pound or more of PCBs (roughly equivalent to 12-16 fluorescent baliasts) in a 24-hour period.

As a generator of PCB-containing ballast wastes, you could be liable in any subsequent Superfund cleanup at a municipal, hazardous, or chemical land disposal site, incinerator, or recycling facility.

EPA encouraged proper disposal of PCB-containing ballasts in the preamble to the 1979 PCB Ban Rule (44 FR 31514) and in the preamble to the final rule on August 25, 1982 (47 FR 37342).

"The EPA encourages commercial and industrial firms that use and dispose of large quantities of small PCB capacitors to establish voluntarily a collection and disposal program that would result in the waste capacitors going to chemical or hazardous waste landfills or high-temperature incinerators.". 


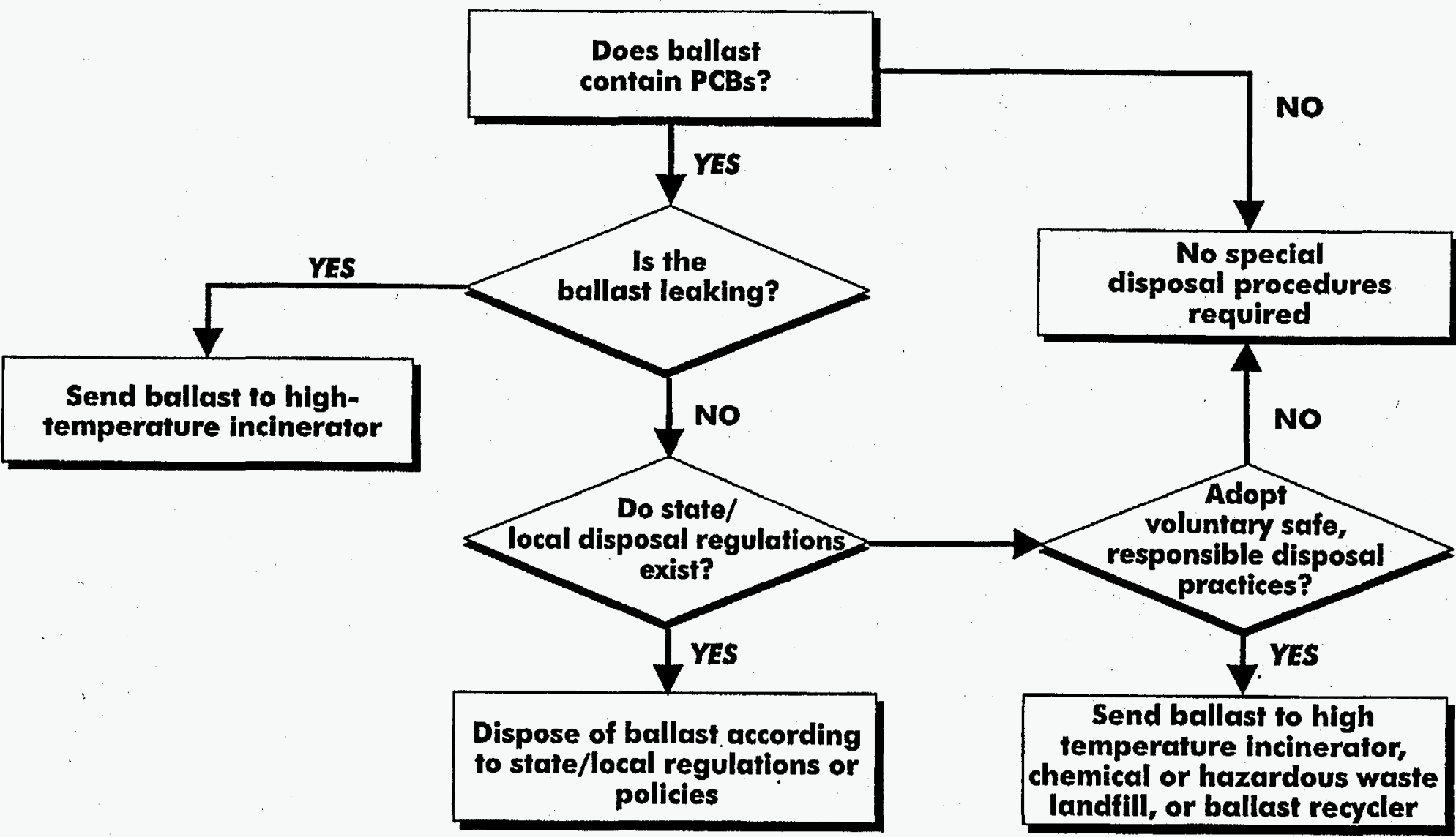




\section{Leaking PCB Ballast Disposal}

A puncture or other damage to ballasts in a lighting system exposes an oily tar-like substance. If this substance contains PCBs, the ballast and all materials it contacts are considered $P C B$ waste, and are subject to TSCA requirements. Leaking PCB-containing ballasts must be incinerated at an EPA-approved high-temperature incinerator. (See last section for a ist of incinerators).

It is very important that you remove, handle, and dispose PCB-containing ballasts property. Take precautions to prevent exposure of the leaking ballast, since all materials that contact the ballast or the leaking substance are also PCB waste. Use trained personnel or contractors to handle and dispose leaking PCB-containing ballasts.

For proper packing, storage, transportation, and disposal information call the TSCA assistance information hotline at (202) 554-1404.

\section{State Requirements}

\section{Non-Leaking PCB Ballast Disposal}

Many states have developed regulations governing the disposal of non-leaking PCB-containing ballasts that are more stringent than Federal regulations. In addition, some EPA Regional offices published policies specifying ballast disposal methods adopted by individual states.

State standards can take several forms (e.g., written regulations, regional policies, written and verbal recommendations, transportation documentation). Some states do not regulate PCB-containing ballasts as toxic waste, but prohibit their disposal in municipal solid waste landfills. The table on the next page provides a listing of state regulations and recommendations. The last section of this document lists solid and hazardous waste agencies for states and EPA Regions.

All generators of PCB-containing ballasts should thoroughly investigate their state's regulations and follow local requirements.

Green Lights recommends three methods for disposing of non-leaking PCB-containing ballasts: high-temperature incineration, recycling, and chemical or hazardous waste landfill.

When upgrading lighting, make sure your contractor removes all disconnected $P C B$-containing ballasts from the lighting fixtures. Non-leaking PCB-containing ballasts may still be hazardous if left in upgraded fixtures, especially in case of fire.

\section{High-Temperature Incineration}

High-temperature incineration is the method preferred by many companies because it destroys PCBs, removing them from the waste stream permanentfy and removing the potential for future CERCLA liability. Incinerating a PCB-containing ballast costs more than sending it to a hazardous waste landfill, but this additional cost is one many organizations are willing to absorb.

\section{Recycling Ballasts}

Recyclers remove the PCB-containing materials (i.e., the capacitor and possibly the asphalt potting material surrounding the capacitor) for incineration or land disposal. Metals, such as copper and steel, can be reclaimed from the ballasts for use in manufacturing other products. You may recycle used non-leaking ballasts despite PCBs. The last section of this document contains a list of companies that recycle ballasts.

\section{Chemical or Hazardous Waste Landfill}

PCB-containing ballasts may also be disposed in a chemical or hazardous waste landfill. Landfill disposal is less expensive than high-temperature incineration or recycling, but does not eliminate $\mathrm{PCBs}$ from the waste stream permanently. While chemical or hazardous waste landfill disposal is an acceptable, regulated disposal method, your organization may be legitimately concerned about potential future CERCLA liability using this method.

\section{Packing PCB Ballasts for Disposal}

Despite the disposal method selected, ballasts are packed - according to PCB regulations - in 55-gallon drums for transportation.

One drum holds 150 to 300 ballasts depending on how tightly the ballasts are packed.

$\varpi$

Fill void space with an absorbent packing material for safety reasons.

Label drums according to Department of Transportation regulations.

Note that tightly packed drums may weigh more than 1,000 pounds, which may present a safety risk, particularly when moving the drum for loading or unloading. 


\section{STATE REGULATIONS REGARDING BALLAST DISPOSAL}

\begin{tabular}{|c|c|}
\hline State & Comments \\
\hline AK & Follow Federal Regulations. \\
\hline AL & In-State landfill requires prior approval. Recommend incineration or chemical waste landfill. \\
\hline AR & Foliow Federal Regulations. \\
\hline AZ & Municipal landfill requires approval trom landfill operator. \\
\hline CA & PCBs $>50 \mathrm{ppm}$ are hazardous waste and must be placed in lab packs and disposed in hazardous waste landfill or incinerated. \\
\hline $\mathrm{CO}$ & $\begin{array}{l}\text { Non-leaking PCB ballasts require prior approval from solid waste landfill operator. Leaking PCB ballasts must be sent to high- } \\
\text { temperature incinerator in accord to TSCA regulations. Non-PCB ballasts require approval from solid waste tandfill operator }\end{array}$ \\
\hline CT & PCB ballasts must be incinerated or sent to a chemical waste landfiil. \\
\hline $\mathrm{DE}$ & Follow Delaware Regulations Goveming Hazardous Waste (DRGHW). \\
\hline FL & Follow EPA Region 4 Policy. \\
\hline GA & Follow EPA Region 4 Policy. \\
\hline IA & Follow Federal Regulations. \\
\hline ID & $\begin{array}{l}\text { PCB-containing ballasts are govemed according to EPA Region } 10 \text { policy (leaking ballasts or generation of more than } 5 \text { ballasts' } \\
\text { year must be handled as PCB waste). }\end{array}$ \\
\hline$\underline{L}$ & Leaking PCB-containing ballasts meet definition of special waste $(35 \mid \mathrm{AC})$. \\
\hline IN & Disposing > 25 small capacitors of ballasts/day requires approval (329 IAC 4-1-10 (b) (1)). \\
\hline KS & Follow Federai Regulations. \\
\hline KY & Recommend recycling, chemical landfill, or incineration: \\
\hline LA & PC8s > 50 ppm considered hazardous waste. \\
\hline MA & Follow Federal Regulations. \\
\hline MD & $\begin{array}{l}\text { PCBs }>500 \text { ppm regulated as acute hazardous waste. } 1 \mathrm{~kg} \text { (based on entire weight of the ballasts) subject to full regulation as } \\
\text { hazardous waste. Average limit is } 1-2 \text { ballasts. }\end{array}$ \\
\hline ME & PCBs $>50 \mathrm{ppm}$ regulated as hazardous waste. \\
\hline MI & Follow EPA Region 5 policy. \\
\hline MN & PCBs $>750$ ppm regulated as hazardous waste. Ballasts may be handled as a special hazardous waste. \\
\hline MO & Follow Federal regulations. \\
\hline MS & PCB $>50$ pom not allowed in municipal solid waste landfills. \\
\hline MT & Follow Federal Regulations. \\
\hline NC & PCB $>50$ ppm not allowed in municipal solid waste landfills. \\
\hline ND & $\begin{array}{l}\text { EPA has enforcement authority. ND encourages recycling through EPA approved process, TSCA incineration, or chemical } \\
\text { landfills. Regulated PCB waste includes leaking PCB capacitors and ballast tar }>50 \mathrm{ppm} \text { PCB. }\end{array}$ \\
\hline $\mathrm{NE}$ & Follow Federal Regulations. \\
\hline NH & Follow Federal regulations. \\
\hline NJ & PCBs $>50 \mathrm{ppm}$ considered hazardous waste. \\
\hline NM & Follow EPA Region 6 policy. \\
\hline NY & Ballast disposal must comply with $6 N Y C R R$ Part 364 (permitting of waste haulers) and $6 N Y C R R$ Part 360 (solid waste disposal). \\
\hline $\mathrm{OH}$ & Follow Federal Regulations. \\
\hline OK & Follow Federal Regulations. \\
\hline OR & Follow EPA Region 10 policy ( $>5$ ballasts/year must be incinerated or sent to chemical waste landfill.) \\
\hline PA & PCBs $>50$ ppm regulated by DER. \\
\hline RI & PCBs $>50 \mathrm{ppm}$ regulated as hazardous waste. \\
\hline SC & Follow Federal Regulations. \\
\hline SD & $\begin{array}{l}\text { PCB ballasts are allowed to be disposed of at municipal landfills as long as the generator is not in the business of manufacturing } \\
\text { these items. }\end{array}$ \\
\hline TN & Follow Federal regulations. \\
\hline TX & PCBs > 50 ppm are hazardous waste. \\
\hline UT & Follow Federal regulations. \\
\hline VA & $\begin{array}{l}\text { PCB-containing materials regulated as Special Solid Waste. PCBs }>50 \mathrm{ppm} \text { may NOT be disposed or stored without EPA } \\
\text { approval. PCBs between } 1 \text { and } 50 \mathrm{ppm} \text { restricted to disposal in sanitary landfills or industrial waste landfills. }\end{array}$ \\
\hline VT & PCBs $>50 \mathrm{ppm}$ regulated as hazardous waste. \\
\hline WA & Follow EPA Region 10 policy ( $>5$ ballastshyr must be incinerated or sent to chemical waste landfill.) \\
\hline W! & Regulates all PCBs $>50 \mathrm{ppm}$ as PCB waste. \\
\hline Wv & Follow EPA Region 3 policy. \\
\hline WY & Racommend recycling of all ballasts. Follow EPA Region 8 policy. \\
\hline Wash.DC & Follow Federal Regulations. \\
\hline
\end{tabular}




\section{PCB Ballast Disposal Costs}

High-temperature incineration and chemical or hazardous waste landfill costs can vary considerably. Disposal prices vary according to the following.

quantity of waste generated

location of removal site

proximity to an EPA-approved high-temperature incinerator or chemical or hazardous waste landfill

\section{state and local taxes}

When shopping for ballast disposal services, request cost estimates in terms of both pounds and number of ballasts. Typical $F 40$ ballasts weigh about $3.5 \mathrm{lbs}$., and $F 96$ ballasts weigh about $8 \mathrm{lbs}$. Negotiate with hazardous waste brokers, transporters, waste management companies, and disposal sites to obtain the lowest fees.

\section{High-Temperature Incineration Costs}

Incineration costs are calculated by weight.

- Costs range from $\$ 0.55 / \mathrm{b}$. to $\$ 2.10 / \mathrm{b}$.

- Average cost is $\$ 1.50 / \mathrm{b}$., which equals approximately $\$ 5.25$ per ballast.

Note: Estimated costs do not include packaging, transportation, or profile fees.

\section{Recycling Costs}

When recyclers remove the PCB-containing capacitor, the volume and weight of the ballast are reduced. This change results in lower packing, transportation, and incineration or disposal costs.

Recycling costs are calculated by weight.

- Costs range from $\$ 0.75 / \mathrm{b}$. to $\$ 1.75 / \mathrm{b}$.

- Average cost is $\$ 1.00 / \mathrm{b}$., which equals approximately $\$ 3.50$ per ballast.

Note: Recycling cost can range from $\$ 1.25$ per ballast (if the PCB wastes are sent to a chemical or hazardous waste landfill) to approximately $\$ 3.50$ per ballast (if the PCB wastes are high-temperature incinerated). Estimated costs do not include packaging, transportation, or profile fees.

\section{Chemical or Hazardous Waste Landfill Costs}

Chemical or hazardous waste landfill costs are calculated per 55-gallon drum.

- Costs range from $\$ 65 /$ drum to $\$ 165 /$ drum.

- Average cost is $\$ 100 /$ drum, which equals approximately $\$ 0.50 /$ ballast.

Note: Estimated costs do not include packaging, transportation, or profile fees.

\section{Transportation Costs}

Transportation fees are calculated as cents per pound per mile. They vary according to (1) the number of drums removed from the site, and (2) the distance from your location to the location of the high-temperature incinerator, chemical or hazardous waste landfilil, or recycler.

Transporters may need to be registered or licensed to move hazardous wastes in certain states.

Documentation of the movement of hazardous waste may be required even if a state does not regulate disposal or require the use of a licensed transporter.

\section{Profile Fees}

Operators of the high-temperature incinerator or chemical or hazardous waste landfill may charge a profile fee to document incoming hazardous waste. Profile fees vary depending on the volume of waste materials generated.

- Profile fees range from $\$ 0$ to $\$ 300$ per delivery.

- Fees may be waived if a certain volume or frequency of deliveries is assured or a working relationship has been established with a waste management broker, lighting management company, or other contractor.

\section{Record Keeping}

To track transported TSCA or hazardous waste, EPA requires generators to prepare a Uniform Hazardous Waste Manifest. The hazardous waste landfill, incinerator, or recycler that you use can provide this one-page form. The manifest identifies the type and quantity of waste, the generator, the transporter, and its ultimate destination. 


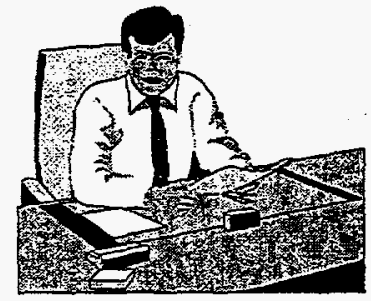

The manifest must accompany the waste wherever it travels. Each handler of the waste must sign the manifest and keep one copy. When the waste reaches its destination, the owner of that facility returns a copy of the manifest to the generator to confirm that the waste arrived. If the waste does not arrive as scheduled, generators must immediately notify EPA or the authorized state environmental agency (see the last section), so that they can investigate and act appropriately.

In addition, require your contractor to provide you with documents verifying the disposal method, whether the PCBs are incinerated at high-temperatures or disposed in a chemical or hazardous waste landfill.

\section{DEHP-CONTAINING BALLASTS}

Di (2-ethyihexyl) phathatlate (DEHP) is a substance that was used to replace PCBs in certain ballast capacitors beginning in 1979. DEHP in its pure form is listed as a hazardous waste under the Resource Conservation and Recovery Act (RCRA). However, once it has been used in a lighting ballast, it is no longer hazardous as defined by RCRA. (See 40 CFR 261.33, Part 261 Appendix VII, Section 268.34, and Section 268.43.)

DEHP is regulated under CERCLA-the Superfund law. The "Reportable Quantity" (RQ) of DEHP under CERCLA is 100 pounds. (See 40 CFR, Section 302.4.) This means that if you are disposing of 100 pounds or more of the material in a 24 hour period (approximately 1,600 fluorescent lighting ballasts), you are required to notify the National Resource Center at (800) 424-8802. it also means that parties involved with the disposal of DEHP ballasts may be held liable under Superfund if clean up of the DEHP is required.

DEHP has been found in ballasts designed for the following lighting fixtures: four foot fluorescent fixtures manufactured between 1979 and 1985; eight foot fluorescent fixtures manufactured between 1979 and 1991; and high intensity discharge (HID) fixtures manufactured between 1979 and 1991. Some ballasts manufactured during these periods may contain dry capacitors or substances other that DEHP. To make sure your ballasts do not contain DEHP, contact the manufacturer or send the capacitor to a laboratory for testing.

\section{MERCURY-CONTAINING LAMPS}

Fluorescent and high-intensity discharge (HID) lamps contain a small quantity of mercury that can be harmful to the environment and to human health when improperly managed. Mercury is regulated under RCRA, which is administered by the US Environmental Protection Agency. Under current Federal law, mercury-containing lamps - such as fluorescent and HID lamps - may be hazardous waste. In addition, incandescent and HID lamps may contain small quantities of lead that can also be potentially harmful to human health and the environment. To prevent these toxic materials from contaminating the environment, dispose of used lamps responsibly.

\section{Federal Regulations}

\section{Resource Conservation and Recovery Act (RCRA)}

RCRA requires generators of solid wastes containing toxic constituents (such as mercury) to determine whether or not the waste is hazardous by using generator knowledge or testing representative samples of that waste. According to RCRA, generators of used fluorescent and HID lamps are responsible for determining whether their lamp wastes are hazardous. If you do not test used fluorescent and HID lamps and prove them non-hazardous, assume they are hazardous waste and dispose them accordingly.

\section{Generator Knowledge}

To use generator knowledge in making a hazardous waste determination, the generator must have information on possible hazardous constituents and their quantities in the waste. Sometimes manufacturers generate solid waste as part of their manufacturing process, and can use process knowledge to determine whether the waste exhibits a characteristic of hazardous waste. However, with expired lamp wastes the generator has little process knowledge on which to make a hazardous waste determination (since he is not the manufacturer). The generator could base a determination on data obtained from the manufacturer, or he could refer to EPA's study entitled "Analytical Results of Mercury in Fiuorescent Lamps" (dated 5/15) 92, available in EPA's RCRA docket). 


\section{Testing Lamps To Determine If They Are Hazardous Waste}

The Toxicity Characteristic Leaching Procedure (TCLP) identifies whether a waste is toxic and must be managed as hazardous waste. The test attempts to replicate the conoitions in a municipal landfill to detect the mercury concentration of water that would leach from the landfill. If the mercury concentration exceeds 0.2 milligrams per liter, the lamp fails the toxicity test and is managed as hazardous waste.

When mercury-containing lamps are tested using the TCLP, the test results can vary considerably, depending on the lamp manufacturer, the age of the lamp, and the laboratory procedures used. These lamps often fail the TCLP. If you do not use the TCLP to verify that your lamps are non-hazardous, you should (1) assume that they are hazardous waste, and (2) manage them as hazardous waste. Contact your state hazardous waste agency for information on laboratories in your state that conduct the TCLP test. The cost to test one lamp is approximately $\$ 140$. However, due to variability in TCLP testing for lamps, EPA recommends that more than one lamp be tested to make a hazardous waste determination.

For more information on RCRA regulations and waste identification, storage, transportation, and disposal, contact the RCRA hotline at 1-800-424-9346 (in the District of Columbia call 703-412-9810).

\section{Conditionally Exempt Small Quantity Generators}

A conditionally exempt small quantity generator, as defined under RCRA, is a generator who disposes $100 \mathrm{~kg}$ or less of hazardous waste per month. Generators must add the weight of all the hazardous waste (lamps plus other hazardous wastes) that their business generates during a month. For lamp disposal, this quantity of waste includes the mercury in the lamp along with the glass, phosphors, and other materials (the weight of the entire lamp).

Conditionally exempt small quantity generators are excused from RCRA identification, storage, treatment and disposal regulations. To qualify as a conditionally exempt small quantity generator (if the only hazardous waste is mercury-containing lamps), a generator must dispose of fewer than 300-350 four-foot T12 fluorescent lamps or $400-450$ four-foot T8 fluorescent lamps per month, depending upon the approximate weight of each lamp. EPA encourages all users of fluorescent and HID lamps to dispose of mercury-containing lamps responsibly to limit the release of mercury into the environment.

\section{Comprehensive Environmental Response, Compensation, and Liability Act (CERCLA)}

CERCLA also regulates the disposal of mercurycontaining lamps. The law requires building owners and waste generators to notify the National Response Center at (800) 424-8802 under certain conditions. For example, they must notify if they dispose of a pound or more of mercury (roughly equivalent to 11,000 four-foot T12 fluorescent lamps) in a 24-hour period. All generators of mercury-containing lamp waste (large, small, and conditionally exempt small generators) could be held liable in any subsequent Superfund cleanup at a land disposal site, incinerator, storage site, or recycling or other treatment facility.

\section{State Regulations}

States may develop regulations that are more stringent than current Federal requirements. Several states are currently considering regulations that will affect the transportation, storage, and/or disposal of mercurycontaining lamps. Check with your Regional EPA office or state agency to confirm the most current rules and information on fluorescent and HID lamp waste management in your state.

\section{Disposal of Used Fluorescent and HID Lamps}

The following sections outline the storage, packing, transportation and disposal options for used mercurycontaining lamps discarded as hazardous waste.
Used lamps that test hazardous or are determined hazardous by the generator must be disposed of at a hazardous waste landfill or sent to a lamp recycling facility. Mercury-containing lamps should never be incinerated. Most municipal incinerators and solid waste combustors lack the necessary control technologies to effectively remove mercury from the flue gas before it is released into the atmosphere. 


\section{STATE REGULATIONS REGARDING MERCURY-CONTAINING LAMP DISPOSAL}

\begin{tabular}{|c|c|}
\hline State & Comments $\quad$ Com \\
\hline AL & $\begin{array}{l}\text { Lamps failing TCLP test are handled as hazardous waste, including hazardous waste transporter requirements. Lamps and } \\
\text { bulbs that are recycled are NOT subject to reduced hazardous waste management requirements. }\end{array}$ \\
\hline AK & Follow Federal (RCRA) regulations. \\
\hline$A Z$ & Foilow Federal (RCRA) regulations. \\
\hline AR & Follow Federal (RCRA) regulations. \\
\hline CA & Over 25 lamps per 24 hour period must be disposed of as hazardous waste. \\
\hline $\mathrm{CO}$ & $\begin{array}{l}\text { Lamps exhibiting a characteristic of a hazardous waste would be, expected to be managed in accordance with the colorado } \\
\text { Hazardous Waste Act. Non-hazardous lamps can be disposed in solid waste landfill with prior approval of landfill operator. }\end{array}$ \\
\hline CT & $\begin{array}{l}\text { Mercury-containing lamps are subject to Federal (RCRA) regulations through TCLP testing, and if they fail the TCLP test , must } \\
\text { be treated as a hazardous waste. }\end{array}$ \\
\hline$\overline{\mathrm{DE}}$ & $\begin{array}{l}\text { Lamps failing TCLP test must be managed and disposed of as a hazardous waste. Onsite storage of fluorescent lamps } \\
\text { determined to be hazardous waste, for periods in excess of those allowable by DRGHW for the individual generatorAEs status, } \\
\text { would require a Treatment, Storage and Disposal Facility (TSDF) permit or hazardous waste Transfer Facility approval. } \\
\text { Shipments of all hazardous waste lamps offsite must be initiated to a permitted TSDF via a permitted hazardous waste } \\
\text { transporter. Each shipment must be accompanied by a Uniform Hazardous Waste Manifest. }\end{array}$ \\
\hline $\mathbf{F L}$ & $\begin{array}{l}\text { After July } 1,1994 \text {, lamps may not be burned in any municipal waste incinerator. Generators of }>10 \text { lamps/month must arrange } \\
\text { disposal in permitted lined landfills or recycling at mercury reclamation facilities in accordance with Florida Department of } \\
\text { Environmenta! Protection (FDEP) guidelines. }\end{array}$ \\
\hline GA & Follow Federal (RCRA) regulations. \\
\hline IA & Lamps failing TCLP test are considered hazardous waste. Recycling recommended. EPA RCRA transportation reguirements apply. \\
\hline ID & $\begin{array}{l}\text { Follow Federal (RCRA) regulations. Conditionally-exempt generators may dispose of mercury-containing lamps in a municipal } \\
\text { landfill with prior approval from the landfill operator. }\end{array}$ \\
\hline IL & Lamps exhibiting the toxicity characteristic are subject to hazardous waste management. EPA has enforcement authority in IL. \\
\hline IN & Subject to RCRA through TCLP testing and may be regulated as hazardous waste under 329 IAC 3.1. \\
\hline KS & Follow Federal (RCRA) requlations. \\
\hline KY & Follow Federal (RCRA) requlations. \\
\hline LA & Follow Federal (RCRA) regulations. \\
\hline MA & Can be shipped to a recvcler without manifest. \\
\hline MD & $\begin{array}{l}\text { Lamps exhibiting the toxicity characteristic subject to hazardous waste regulations. Persons who generate } 100 \mathrm{~kg} \text { or more of } \\
\text { hazardous waste or who accumulate } 100 \mathrm{~kg} \text { or more of hazardous waste at any time (all hazardous waste, not just lamps) are } \\
\text { fully regulated hazardous waste generators. }\end{array}$ \\
\hline ME & Waste that contains $0.2 \mathrm{mg} / \mathrm{l}$ or greater of mercury (tluorescent lamps) are regulated as hazardous waste. \\
\hline M! & Lamps which fail TCLP test are hazardous waste, recommend recycling. \\
\hline MN & Mercury containing lamps must be stored according to Minnesota Pollution Control Agency (MPCA) guidelines and shipped to \\
\hline & an existing recycling facility in accordance with MPCA requirements. \\
\hline MO & Recommend management as potentially hazardous waste. \\
\hline MS & Follow Federal (RCRA) regulations. \\
\hline MT & Follow Federal (RCRA) requlations. \\
\hline NC & $\begin{array}{l}\text { Hazardous waste lamps and bulbs (including bulbs with RCRA metals above regulatory level) from a commercial source must NOT } \\
\text { be placed in a municipal solid waste landfill. intact lamps and bulbs that are regucled are subject to reduced management requirements. }\end{array}$ \\
\hline ND & Encourage recycling. Must be managed as a hazardous waste when total quantities of all hazardous waste from a facility is $>$ \\
\hline & 220 bs/month. Each Subtitle D landfill determines their acceptance of exempt quantities. \\
\hline NE & $\begin{array}{l}\text { Follow Federal (RCRA) regulations. Small-quantity generators need state approval for special waste disposal in solid waste } \\
\text { (Subtitle D) landfill. A hazardous waste manifest is required for all regulated generators of hazardous waste. A bill of lading is } \\
\text { recommended for all conditionally exempt generators. }\end{array}$ \\
\hline NH & Hazardous fluorescent lamps that are NOT designated for recycling or which are broken are subject to NH hazardous waste rules. \\
\hline NJ & Follow Federal (RCRA) regulations. \\
\hline NM & Recommend Recycling. Follow Federal (RCRA) regulations. \\
\hline NY & $\begin{array}{l}\text { Mercury-containing lamps must comply with the hazardous waste management regulations (6NYCRR Parts } 370-374 \text { and } 376 \text { ) } \\
\text { if they fail TCLP test for any hazardous constituent. }\end{array}$ \\
\hline $\mathrm{OH}$ & Lamps designated for recycling are NOT considered hazardous waste, and are not subject to Ohio hazardous waste regulations. \\
\hline OK & Follow Federal (RCAA) regulations. \\
\hline OR & Follow Federal (RCRA) regulations. \\
\hline $\mathrm{PA}$ & Landfill only when certification shows that waste has passed the TCLP test. \\
\hline RI & Treat as hazardous waste. Log system is used for transporters and generators. \\
\hline SD & Follow Federal (RCRA) requlations. \\
\hline SC & Follow Federal (RCRA) requlations. \\
\hline$T N$ & $\begin{array}{l}\text { Follow Federal (RCRA) regulations. Tube crushers must meet state regulations. State approval is required for disposal of non- } \\
\text { hazardous lamps and hazardous waste from small-quantity generators in solid waste (Subtitle D) landfills. }\end{array}$ \\
\hline$\overline{T X}$ & Follow Federal (RCRA) regulations. \\
\hline UT & Follow Federal (RCRA) regulations. \\
\hline VA & Follow Federal (RCRA) regulations. \\
\hline WA & Recommends recycling. \\
\hline WI & $\begin{array}{l}\text { Hazardous waste lamps and bulbs (inciuding bulbs with high lead concentrations) may not be placed in a solid waste landill. } \\
\text { Lamps and bulbs that are recycled are subject to reduced hazardous waste management reguirements. }\end{array}$ \\
\hline WY & Recommend recycling. \\
\hline Wash Do & \\
\hline
\end{tabular}

Lighting Waste Disposal • Lighting Upgrade Manual • EPA's Green Lights Program • March 1995 


\section{Hazardous Waste Landfill}

A hazardous waste landfill - also known as a RCRA Subtitle $C$ facility - is a landfill that is permitted under Subtitle $C$ of RCRA and is engineered to contain hazardous waste. Incoming wastes are manifested by the facility and some incoming wastes are subject to treatment standards.

\section{Recycling Fluorescent and HID Lamps}

Any lamp may be recycled at permitted or licensed recycling facilities, regardiess of whether the lamp tests hazardous. However, for lamps that are hazardous waste, generators must follow generation, transport, and storage requirements under RCRA Subtitle C. Recycling separates the toxic substances (such as mercury) from the glass, aluminum, and other lamp components, and all materials may be re-used in manufacturing other products. Some lamp recycling companies recycle HID lamps as well as fluorescent lamps. A list of companies that provide lamp recycling services is included in the last section.

\section{Lamp Disposal Costs}

The costs for lamp disposal by recycling or hazardous waste landfill can vary considerably. Prices vary according to the following.

- quantity of waste generated

- location of disposal site

- proximity to a permitted hazardous waste landfill or recycling facility

- state and local taxes

Negotiate with hazardous waste brokers, transporters, waste management companies, and disposal sites to obtain lowest fees.

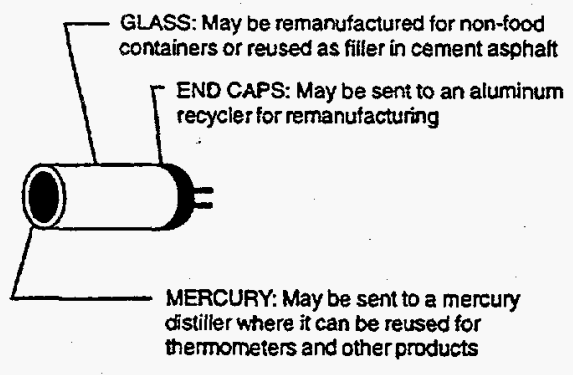

\section{Recycling Costs}

Recycling costs for fluorescent lamps are typically calculated by linear foot. HID lamp recycling costs are typically quoted on a per-lamp basis.

- fluorescent recycling costs range from $\$ 0.06 / f t$ to $\$ 0.15 / \mathrm{tt}$

- average cost is $\$ 0.10 / f t$

- approximately $\$ 0.40$ per F40 lamp

- HID recycling costs range from $\$ 1.25$ /lamp to $\$ 4.50 /$ lamp

- average cost is $\$ 2.50 /$ lamp

Note: Estimated costs do not include packaging, transportation, or profile fees.

\section{Chemical or Hazardous Waste Landfill Costs}

Disposal costs for fluorescent lamps at a hazardous waste landill range from 25-50 cents per 4-foot tube, not including costs for packaging, transportation, or profile fees.

\section{Packing Lamps for Disposal}

To prevent used fluorescent and HID lamps from breaking, lamps should be properly packed for storage and transportation. When lamps are removed and replaced with new lamps (e.g., during group relamping), the used lamps should be packed in the cardboard boxes that contained the replacement lamps. The boxes containing the hazardous waste must be properly labeled. Pre-printed labels or rubber stamps that meet Department of Transportation regulations are recommended for high-volume disposal.

\section{Storing Lamps for Disposal}

RCRA sets storage requirements for generators depending on how much hazardous waste they dispose each month.

- Small quantity generators dispose 100 to $1,000 \mathrm{~kg}$ of hazardous waste per month (which roughly corresponds to 350 to 3,600 four foot lamps), and can store hazardous waste up to 180 days.

- Large quantity generators dispose over $1,000 \mathrm{~kg}$ of hazardous waste per month (more than 3,600 four foot lamps), and can store hazardous waste up to 90 days.

- Conditionally exempt small quantity generators dispose $100 \mathrm{~kg}$ or less of hazardous waste per month and are exempt from RCRA storage requirements. 
In addition to proper packing, care should be taken when stacking the boxes of used lamps for storage to avoid crushing the bottom boxes under the weight of the boxes on top. If you work with a contractor to maintain your lighting system, you may want to specify a safe storage arrangement in your contract. This approach ensures that your used lamps are not accidentally broken or crushed before they are sent to a disposal facility.

Some organizations crush their used lamps before disposal. This option should be pursued with care. The crushing equipment should have the approval of state and local authorities, and crushing methods should be evaluated carefully. The lamp should be crushed entirely inside the drum or storage unit so that no mercury vapor enters the atmosphere. There should also be adequate ventilation in the space where the crushing occurs. Under current EPA hazardous waste regulations, crushing lamps before sending them to a hazardous waste landfill may be considered treatment. Therefore, a RCRA treatment permit may be required.

\section{Transportation}

Registered haulers and other transporters of hazardous waste calculate transportation fees as cents per pound per mile. The costs will vary according to the number of lamps, drums, or other containers to be removed from the site and the distance from your location to the location of the hazardous waste landfill or recycling facility.

\section{Profile Fees}

Operators of chemical or hazardous waste landfills may charge a profile fee to document incoming waste. Profile fees vary depending on the volume of waste materials generated and may be waived if a certain volume or frequency of deliveries is assured. Establishing a working relationship with a lighting management company or lighting maintenance contractor who assists with the maintenance of your lighting system can reduce your disposal costs.

\section{Record Keeping}

To track transported waste, EPA requires generators to prepare a Uniform Hazardous Waste Manifest. This one-page form can be provided by the recycler or hazardous waste landfill where you dispose of your used fluorescent or HID lamps. The manifest identifies the type and quantity of waste, the generator, the transporter, and the facility to which the waste is being shipped. The manifest must accompany the waste wherever it travels. Each handler of the waste must sign the manifest and keep one copy. When the waste reaches its destination, the owner of that facility returns a copy of the manifest to the generator to confirm that the waste arrived. If the waste does not arrive as scheduled, generators must immediately notify EPA or the authorized state environmental agency (see the last section), so that they can investigate and take appropriate action.

In addition, require your contractor to provide you with documentation verifying that the lamps were properly recycled or disposed in a hazardous waste landfill.

\section{Municipal Solid Waste Landfill}

Lamp wastes generated in small quantities (see "Conditionally Exempt Small Quantity Generators" in the previous section) and used fluorescent and HID lamps that do not test hazardous under RCRA may be disposed in a properly managed municipal solid waste landfill (RCRA Subtitle D facility). The municipal landfill may impose restrictions or regulate incoming wastes in accordance with local rules or company guidelines. Disposal costs for lamps at a Subtitle D municipal solid waste landfill are approximately 2-3 cents per 4-foot lamp.

Generators may be legitimately concerned about potential future Superfund liability in connection with this disposal method. All generators of mercurycontaining lamp waste, regardless of size, could be held liable in any subsequent Superfund cleanup at a municipal solid waste landfill.

\section{EVALUATING DISPOSAL OPTIONS}

\section{Liability Issues}

Under CERCLA, owners and operators of facilities and persons disposing hazardous substances may be held liable for response costs, if there is a release or threat of a release of a hazardous substance into the environment. Liability under CERCLA is broad and potentially costly, and can apply retroactively. All generators may incur Superfund liability for disposing mercury-containing lamps or PCB-containing ballasts in a dumpster, local landfill, or recycling, storage, or treatment facility. Disposal of mercury wastes or PCBs in an environmentally sound manner, however, will help to minimize the potential for environmental contamination and thus also minimize the potential for liability. 


\section{Impact of Lamp Disposal Cost on Profitability}

The overall impact of lamp disposal on the profitability of typical Green Lights lighting upgrade projects is minimal. The example below shows the impact of various lamp recycling costs on the internal rate of retum (IRR) and the net present value (NPV) of a typical lighting upgrade project. The assumed project consists of upgrading a 4-lamp standard fluorescent system that uses magnetic ballasts and 40-watt lamps with a 4-lamp T8/electronic system and occupancy sensors. Without considering the cost of lamp disposal, the IRR and NPV were calculated at $47.1 \%$ and $\$ 52,242$, respectively. Note that even when assuming lamp disposal costs of $\$ 1.50$ per lamp three times the average recycling cost - the IRR and NPV values decreased only slightly to $44.8 \%$ and $\$ 51,642$, respectively. These results were obtained using the Green Lights analysis tool Quikalc.

\begin{tabular}{|c|c|c|}
\hline \multicolumn{3}{|c|}{$\begin{array}{c}\text { Disposal Costs } \\
\text { (per lamp) }\end{array}$} \\
\hline $\begin{array}{c}\text { Lamp } \\
\text { Disposal } \\
\text { Cost }\end{array}$ & IRR & NPV \\
\hline No fee & $47.1 \%$ & $\$ 52,242$ \\
\hline$\$ 0.50$ & $46.3 \%$ & $\$ 52,042$ \\
\hline$\$ 1.00$ & $45.5 \%$ & $\$ 51,842$ \\
\hline$\$ 1.50$ & $44.8 \%$ & $\$ 51,642$ \\
\hline$\$ 2.00$ & $44.1 \%$ & $\$ 51,442$ \\
\hline$\$ 2.50$ & $43.4 \%$ & $\$ 51,242$ \\
\hline$\$ 3.00$ & $42.7 \%$ & $\$ 51,042$ \\
\hline$\$ 3.50$ & $42.1 \%$ & $\$ 50,842$ \\
\hline
\end{tabular}

Quikalc Assumptions

$63 \%$ energy savings

Before: $2 \times 4$ 4-lamp fixture, $40 \mathrm{~W} T 12$ lamps, standard ballasts After: $2 \times 44$-lamp fixture, $32 W$ T8 lamps, electronic ballasts, occupancy sensors, $25 \%$ operating hour reduction

\section{FLUORESCENT LAMP LIFE-CYCLE COST}

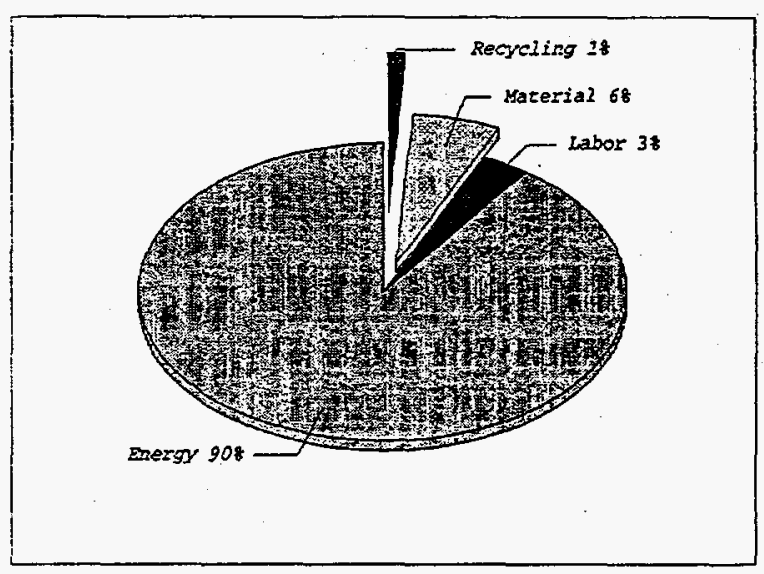

The total cost of disposing of a lamp as a hazardous waste either by recycling or using a hazardous waste landfill can be put into perspective in three additional ways.

First, the cost of operating a lamp (including ballast losses) for its 20,000-hour life is $\$ 64$ at the national average electric rate of 7 cents per kilowatt-hour. The 50-cent disposal cost is quite modest in comparison.

Second, replacing an old fixture with a new one usually costs about $\$ 100-\$ 150$, including installation.

Disposing of an old fixture's lamps will cost approximately $\$ 2$, depending on market conditions and disposal services purchased. If the new fixture uses half the electricity of the old fixture (as is typical with Green Lights upgrades), then the electric bill savings will pay for the cost of disposing of the old lamps after 310 hours of operation - about one month for most businesses. Essentially, lamp disposal will extend the payback of a project by approximately one month.

Third, as shown in the pie chart, the cost of disposing of a lamp as hazardous waste either by recycling or using a hazardous waste landfill represents only a small fraction of the total life-cycle operating costs of a lighting system. If operating a 2-lamp T8/electronic system, disposal as a hazardous waste represents only about 1 percent of total life-cycle operating costs. 
- T8 lamps contain about $30 \mathrm{mg}$ of mercury compared to $40 \mathrm{mg}$ for $\mathrm{T} 12$ lamps

- so less mercury is disposed of during relamping

- T8 lamps are more energy efficient than T12 lamps

- so less mercury is emitted from fossilfueled generating plants*

*(average emission is $0.04 \mathrm{mg} / \mathrm{kWh}$ )

\section{Mercury Emissions and the Environment}

The largest man-made sources of mercury in the atmosphere are fossil fuel combustion ( $58 \%$ of total) and municipal solid waste incineration ( $37 \%$ of total). When the mercury in a fossil fuel is heated in a combustor, it turns into a vapor. In vapor form, mercury is difficult to remove from the flue gas and easily escapes into the atmosphere. When moisture vapor in the atmosphere tums to rain, mercury returns to the earth and is deposited in streams, lakes, and other waterways.

The mercury that is released into the atmosphere by burning fossil fuels can be substantially minimized using efficient lighting technologies.

On average, fossil-fueled power plants emit 0.04 milligrams of mercury per kilowatt-hour sold. By maximizing the efficiency of your lighting system, you can minimize mercury emissions from the power plants that provide your electricity.

The graph on the next page illustrates the long-term benefit of upgrading to an efficient lighting system: overall mercury emissions are significantly reduced.

The amount of mercury emitted into the atmosphere through solid waste incineration and resource recovery facilities (which burn solid waste to produce energy) can be minimized if you adopt a sound lamp disposal practice. EPA will be proposing mercury emission limits for new and existing municipal solid waste incinerators in 1994.

\section{WORKING WITH CONTRACTORS}

Your lighting upgrade project specification should include provisions for proper handling and safe disposal of lamps, ballasts, and other hazardous materials that may be associated with the project.

Here are some general guidelines.

- Investigate your disposal options thoroughly.

- Do not expect your contractor to be well-versed in all disposal requirements and options.

- Ask your lighting or electrical contractor to provide disposal services (either directly or through a subcontractor) as part of their contract.

$\sigma$ Be specific in your disposal requests (e.g., request high-temperature incineration of PCB-containing ballasts at an EPA-approved incinerator).

- Ask for certifications, licenses, and references from all subcontractors providing waste disposal services.

\section{DEFINITIONS}

\section{CERCLA}

The Comprehensive Emergency Response, Compensation and Liability Act of 1980. CERCLA referred to also as "Superfund" - established cleanup and emergency response guidelines for releases of hazardous substances into the environment. A release of a hazardous substance in an amount equal to or greater than its "reportable quantity" (one pound for mercury and $\mathrm{PCBs}$ ) in a 24-hour period triggers CERCLA notification requirements. CERCLA applies to any size generator.

Chemical Waste Landfill

A TSCA permitted landfill that accepts hazardous substances and extremely hazardous waste. These facilities must meet different engineering requirements than RCRA Subtitle $C$ (hazardous waste) landfills.

Conditionally Exempt Small Quantity Generator (SQG) A generator who generates 100 kilograms or less a month of a hazardous waste. Under RCRA, small quantity generators are exempt from RCRA regulations for the transportation, storage, treatment, and disposal of that hazardous waste.

Hazardous Waste Landfill See Subtitle C landfill. 
RCRA

The Resource Conservation and Recovery Act which regulates the management of solid (hazardous and non-hazardous) wastes. Under RCRA, generators of solid wastes are responsible for determining whether the solid wastes are hazardous and following RCRA transportation, storage, treatment, and disposal requirements for those wastes.

\section{RCRA Subtitle C Landfill}

A landfill containing hazardous wastes that is permitted under Subtitle C of RCRA. Land disposal of hazardous wastes is restricted to permitted RCRA Subtitle C disposal facilities.

\section{RCRA Subtitle D Landfill}

A municipal solid waste landfill containing nonhazardous wastes permitted under Subtitle D of RCRA.

\section{TSCA}

The Toxic Substances Control Act of 1976 which regulates the handling, storage, transportation and disposal of polychlorinated biphenyls (PCBs).

\section{INFORMATION RESOURCES}

\section{EPA Regional Offices}

\author{
REGION I (ME, VT, NH, MA, CT, RI) \\ Environmental Protection Agency \\ John F. Kennedy Federal Building \\ Room 2203 \\ Boston, MA 02203 \\ (617) $565-3420$
}

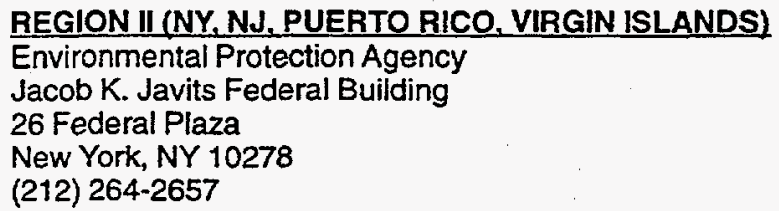

REGION III (PA, WV, VA, MD, DE, WASHINGTON DC) Environmental Protection Agency

841 Chestnut Building

Philadelphia, PA 19107

(215) 597-9800

REGION IV (TN, KY, NC, SC, GA, AL, MS, FL)

Environmental Protection Agency

345 Courtland Street, NE

Atlanta, GA 30365

(404) $347-4727$
REGION V (IL, WI, IN, MI, MN, OH) Environmental Protection Agency 77 West Jackson Boulevard Chicago, IL 60604-3507

(312) $353-2000$

\section{REGION VI (NM, TX, OK, AR, LA)}

Environmental Protection Agency

First Interstate Bank Tower at Fountain Place 12th Floor/Suite 1200

1445 Ross Avenue

Dallas, TX 75202-2733

(214) 665-6444

REGION VII (NE, KS, MO, IA)

Environmental Protection Agency

726 Minnesota Ávenue

Kansas City, KS 66101

(913) $551-7000$

\author{
REGION VIII (MT, WY, ND, SD, UT, CO) \\ Environmental Protection Agency \\ Suite 500 \\ 99918 th Street \\ Denver, CO 80202-2405 \\ (303) 293-1603
}

\section{REGION IX (CA. NV, AZ HI, AMERICAN SAMOA. GUAM) Environmental Protection Agency 75 Hawthome Street San Francisco, CA 94105 (415) 744-1305}

REGION X (WA, OR, ID, AK)

Environmental Protection Agency 1200 Sixth Avenue Seattle, WA 98101 (206) 553-4973

\section{State Solid and Hazardous Waste Agencies}

\section{ALABAMA}

Department of Environmental Management Land Division - Solid/Hazardous Waste 1751 Federal Drive

Montgomery, AL 36130

(205) 271-7761/7735

\section{ALASKA}

Steve Willingham

Manager, Solid Waste Program

State of Alaska

Department of Environmental Conservation 410 Willoughby Avenue Juneau, Alaska 99801-1795 (907)465-5158 


\section{ARIZONA}

Anthony Leverock

Arizona Department of Environmental Quality

Hazardous Waste Permits Unit

3033 North Central Avenue

Phoenix, AZ 85012

(602) $207-4160$

\section{ARKANSAS}

Tom Ezell

Manager, Programs Branch

Department of Pollution Control and Ecology

Hazardous Waste Division

PO BOX 8913

Little Rock, AR 72219-8913

(501) 562-7444

Fax (501) 562-6532

\section{CALIFORNIA}

Mardis Coers

Department of Toxic Substances Control

PO BOX 806

Sacramento, CA 95812-0806

(916) 322-0712

\section{COLORADO}

Scott Klarich

Environmental Compliance Officer

Monitoring and Enforcement Section

Hazardous Materials and Waste Management Division

Colorado Department of Health and Environment

Mail Code: HMWMD-HWC-B2

4300 Cherry Creek Drive South

Denver, CO 80222-1530

(303) 692-3369

\section{CONNECTICUT}

Department of Environmental Protection

Waste Management Bureau

$79 \mathrm{Elm}$ Street

Hartford, CT 06106

(203) $566-8476$

\section{DELAWARE}

Department of Natural Resources and Environmental Control

Division of Environmental Control

Solid Waste/Hazardous Waste Section

Edward Tatnall Building

PO Box 1401

Dover, DE 19901

(302) $739-4403$

Delaware Solid Waste Authority

PO Box 71

New Castle, DE 19901

(302) $736-5361$
DISTRICT OF COLUMBIA

Department of Consumer and Regulatory Affairs Environmental Regulation Administration

Pesticides, Hazardous Waste and Underground

Storage Tank Division

Hazardous Waste Management Branch

(Hazardous Waste Disposal)

2100 Martin Luther King, Jr. Ave. SE,

Suite 203

Washington, DC 20020

(202) 404-1167

Department of Public Works

Public Space Maintenance Administration

Bureau of Sanitation Services

(Solid Waste Disposal/Recycling)

2750 South Capitol St., SE

(202) $767-8512$

\section{FLORIDA}

Raoul Clarke, Environmental Administrator

Bureau of Solid and Hazardous Waste

Department of Environmental Protection

2600 Blair Stone Road

Tallahassee, Florida 32399-2400

(904) 488-0300

\section{GEORGIA}

Vern George

Environmental Protection Agency

Toxics Branch

345 Courtland St., NW

Atlanta, GA 30334

(404) $347-1033$

Department of Natural Resources

Environmental Protection Division

Land Protection Branch

205 Butler Street, SE

Suite 1154

Atlanta, GA 30334

(404) 656-2833

\section{HAWAII}

State of Hawaii

Department of Health

Environmental Management Division

Clean Air Branch

Asbestos Abatement Office

PO Box 3378

Honolulu, HI 96801-3378

(808) 586-8144 
IDAHO

William Fritell

Department of Health and Welfare

Division of Environment

Bureau of Hazardous Materials

450 W. State Street

Boise, ID 83720

(208) $334-5879$

ILLINOIS

Clarence L. Smith

State of Illinois

Environmental Protection Agency

2200 Churchill Road

Springfield, IL 62794-9276

(217) $524-3300$

INDIANA

Robert Snodgrass

Solid Waste Permit Section

105 South Meridian Street

Indianapolis, IN 46206-6015

(317)232-5976

\section{OWA}

Lavoy Haage

Department of Natural Resources

Solid Waste Section

Land Quality Bureau

Wallace State Office Building

900 East Grand Avenue

Des Moines, IA 50319

(515) $281-4968$

KANSAS

Ron Smith

Department of Health and Environment

Solid Waste Management Division

Forbes AFB Bldg. No. 740

Topeka, KS 66620

(913) 296-1500

\section{KENTUCKY}

Abby Myer

Department for Environmental Protection

Division of Waste Management

Ft. Boone Plaza

14 Reilly Road

Frankfort, KY 40601

(502) $564-6716 \times 242$

\section{LOUISIANA}

Department of Environmental Quality

Office of Solid and Hazardous Waste

Solid Waste Division

PO Box 44307

Baton Rouge, LA 70804

(504) 765-0355
MAINE

Department of Environmental Protection Bureau of Oil \& Hazardous Materials Control

State House Station 17

August, ME 04333

(207)287-2651

Waste Management Agency

State House Station 154

August, ME 04333

(207) $287-5300$

\section{MARYLAND}

Ed Hammerburg

Department of Environment

Toxic Operations Program

2500 Boening Highway

Baltimore, MD 21224

(410) 631-3345

\section{MASSACHUSETTS}

Victoria Phillips, Environmental Analyst

Office of Hazardous Waste

Enforcement Division

1 Winter Street

Bosion, MA 02108

(617) 292-5812

MICHIGAN

Department of Natural Resources

Hazardous Waste Division

PO Box 30241

Lansing, MI 48909

(517) $373-2730$

MINNESOTA

Nancy Ellefson

Minnesota Pollution Control Agency

Solid or Hazardous Waste Division

520 Lafayette Road North

St. Paul, MN 55155

(612) $296-6300$

MISSISSIPPI

Russell Smith

Department of Environmental Quality

Office of Pollution Control

PO Box 10358

Jackson, MS 39209

(601) $961-5171$ 
MISSOURI

Department of Natural Resources

Division of Environmental Quality

Waste Management Program

Jefferson State Office Building

205 Jefferson Street

PO Box 176

Missouri Boulevard

Jefferson City, MO 65102

(314) $751-3176$

\section{MONTANA}

Don Vidrine

Department of Health and Environmental Sciences

Environmental Sciences Division

Solid and Hazardous Waste Bureau

PO Box 200901

Helena, MT 59620-0901

(406) 444-1430

NEBRASKA

Department of Environmental Control

PO Box 94877

State Office Building

Lincoln, NE 68509

(402) $471-2186$

NEVADA

Colleen Crips

Bureau of Hazardous Waste

333 West Nye Lane

Carson City, NV 89710

(702) $687-5872$

NEW HAMPSHIRE

Robert C. White, Chief

PCB Section

Department of Environmental Services

Air Resources Division/Toxics Management Bureau 64 N. Main St., Caller Box 2033

Concord, $\mathrm{NH}$ 03302-2033

(603) $271-1370$

Department of Environmental Services

Waste Management Division'Compliance Bureau

6 Hazen Drive

Concord, NH 03301

(603) 271-2942

NEW JERSEY

Sandor Juhasz

NJ Department of Environmental

Protection and Energy

Hazardous Waste Regulation Program

401 East State Street

$\mathrm{CN} 421$

Trenton, NJ 08625

(609) 292-8341
NJ Department of Environmental Protection and Energy

Solid Waste Management Division

840 Bear Tavern Road

CN 44

Trenton, NJ 08625

(609) 292-8341

\section{NEW MEXICO}

New Mexico Environmental Department

Harold Runnels Building

PO Box 26110

Santa Fe, New Mexico 87502

Hazardous and Radioactive Materials Bureau

(505) $827-4308$

Solid Waste Bureau

(505) 827-2775

\section{NEW YORK}

Sharon Rader

Division of Hazardous Substances Regulation

New York State Department of Environmental

Conservation

50 Wolf Road

Albany, NY 12233

(518) $485-8988$

NORTH CAROLINA

Department of Environment, Health, and Natural Resources

Solid Waste Management/Hazardous Waste Division

PO Box 27687

Raleigh, NC 27611

(919) $733-2178$

NORTH DAKOTA

Neil M. Knatterud, Director

Health Department

Division of Waste Management

1200 Missouri Avenue

PO Box 5520

Bismarck, ND 58502-5520

(701) $328-5166$

OHIO

Environmental Protection Agency

Office of Solid and Hazardous Waste

PO Box 1049

1800 Watermark Drive

Columbus, OH 43266-0149

(614) 644-2917

OKLAHOMA

Ellen Bussert

Oklahoma Department of Environmental Quality

Public Information and Education

1000 Northeast 10 th Street

Oklahoma City, OK 73117-1212

(405) $271-7353$ 
OREGON

Gary Galaba

Department of Environmental Quality

Waste Management Clean-up Division

811 S.W. 6th Avenue

Portland, OR 97204

(503) 229-5630

PENNSYLVANIA

Department of Environmental Resources

Bureau of Waste Management

PO Box 8471

Harrisburg, PA 17105-8471

PUERTO RICO

Environmental Quality Board

Solid and Hazardous Waste Bureau

PO Box 11488

Santurce, PR 00910

(809) $725-5140$

\section{RHODE ISLAND}

Robert Nero

Department of Environmental Management

Air and Hazardous Materials

291 Promenade Street

Providence, Rl 02908

(401) $277-2797$

SOUTH CAROLINA

Board of Health and Environmental Control

Bureau of Solid and Hazardous Waste

2600 Bull Street

Columbia, SC 29201

(803) $896-4174$

\section{SOUTH DAKOTA}

Department of Water and Natural Resources

Environmental Health Division

Joe Foss Building

Pierre, SD 57501

(605) $773-3153$

\section{TENNESSEE}

Wayne Gregory, Technical Coordinator

Department of Environment and Conservation

Division of Solid Waste Management

5th Floor, L\&C Tower

401 Church Street

Nashville, TN 37243-1535

(615) $532-0780$

\section{TEXAS}

Alice Hamilton Rogers, P.E., Technical Consultant

Texas Water Commission

PO Box 13087

1700 North Congress Avenue

Austin, TX 78711-3087

(512) $463-7830$

\section{UTAH}

Rusty Lundburg

Department of Environmental Quality

Division of Solid and Hazardous Waste

PO Box 144880

Salt Lake City, Utah 84114-4880

\section{VERMONT}

Stephen Simoes,

Hazardous Materials Coordinator

Department of Environmental Conservation

Hazardous Materials Management Division

103 South Main Street

Waterbury, Vermont 05671-0404

(802) 241-3888

\section{VIRGINIA}

Robert Lincoln, Waste Division

Virginia Department of Environmental Quality Special Solid Waste Program

P.O. Box 10009

Richmond, VA 22240

(804) $527-5357$

\section{WASHINGTON}

Vern Meinz, Environmental Engineer

Department of Ecology

Solid and Hazardous Waste Program

PO Box 47600

Olympia, WA $98504-7600$

(206) 407-6753

WEST VIRGINIA

WV Division of Environmental Protection

Office of Waste Management

1356 Hansford Street

Charleston, WV 25301

(304) 558-5929

\section{WISCONSIN}

Department of Natural Resources

Bureau of Solid Waste Management

101 South Webster Street

Madison, WI 53707

(608) 266-1327

\section{WYOMING}

Department of Environmental Quality

Solid Waste Management Program

122 West 25th Street

(307) $777-7752$ 
TSCA, RCRA, and CERCLA Information Phone Lines

Toxic Substances Control Act (TSCA)

Assistance Information Hotline

(202) 554-1404

RCRAVCERCLA Hotline

(800) 424-9346

in the Washington, DC Metro Area

(703) $412-9810$

CERCLA National Response Center

(NRC) Hotline

(800) 424-8802

\section{EPA-Approved Disposal Locations}

\section{Commercially permitted PCB INCINERATORS \\ operating as of June 1993}

Aptus, Inc.

PO Box 1328

Coffeyville, KS 67337

(316) 251-6380

Aptus, Inc.

Aragonite, UT

(801) 266-7787

Chemical Waste Management

PO Box 2563

Port Arthur, TX 77643

(409) 736-2821

Environmental Energy Group

Denton, TX

(817) $383-3632$

Environmental Energy Group

PO Box 50764

Denton, TX 76206

(817) 898-1291

Rollins

PO Box 609

Deer Park, TX 77536

(713) $930-2300$

\section{Commercially permitted \\ HAZARDOUS WASTE LANDFILLS \\ operating as of June 1993}

Chem-Security Systems Incorporated

Star Route, Box 9

Arlington, OR 98712

(503) 454-2643

Chemical Waste Management

Call 1-800-843-3604 for

information on CWM disposal

facilities nation-wide.

Envirosafe Services Inc. of Idaho

PO Box 16217

Boise, ID 83715-6217

(800) 274-1516

US Ecology, Inc.

Box 578

Beatty, NV 89003

(702) $553-2203$

US Pollution Control, Inc.

Grayback Mountain

$8960 \mathrm{~N} \mathrm{Hwy} 40$

Lake Point, UT 84074

(801) 531-4980

\section{Recycling Resources}

\section{Lamp Recycling Services}

Advanced Environmental Recycling Corp. 2591 Mitchell Avenue

Allentown, PA

(800) $554-2372$ or (215) 797-7608

Allied Technology Group

47375 Freemont Boulevard

Freemont, CA 94538

(510) 490-3008

Alta Resource Management Services

88-B Industry Avenue

Springfield, MA 01104-9926

(800) 730-ALTA or (413) 734-3399

Bethlehem Apparatus

Hellertown, PA

(215) 838-7034 
Dynex Environmental, Inc.

6801 Industrial Loop

Milwaukee, WI 53129

(800) $249-3310$ or (414) $421-4959$

4751 Mustang Circle

St. Paul, MN 55112

(800) $733-9639$ or (612) $784-4040$

Global Recycling Technologies, Inc.

PO Box 651

Randolph, MA 02368

(617) $341-6080$

Light Cycle, inc.

1222 University Avenue

St. Paul, MN 55104

(612) $641-1309$

Lighting Resources, Inc.

386 S. Gordon Street

Pomona, CA

(800) 57-CYCLE

Luminaire Recyclers Inc.

2161 University Avenue, Suite 206

St. Paul, MN 55114

(612) 649-0079

Mercury Recovery Systems

2021 S. Myrtle Street

Monrovia, CA

(818) 301-1372

Mercury Refining Co., Inc.

Albany, NY

(518) $459-0820$

Mercury Technologies intemational, LP

Hayward, CA

(800) 628-3675

Los Angeles, CA

(310) 475-4684

West Melbourne, FL

(407) 852-1516

Mercury Technologies of Minnesota

Pine City Industrial Park

Pine City, MN 55063-0013

(612) 629-7888

(800) $864-3821$

Nine West Technologies

Nastiville, TN

(615) $399-1486$

NSSI, Inc.

574 Etheridge Street

Houston, Texas 77087

(713) 641-0391
Recycle Technologies, Inc. 1480 N. Springdale Road Waukesha, WI 53186

(800) $305-3040$

(414) $798-3040$

Recyclights

2010 E. Hennepin Avenue

Minneapolis, MN 55413

(612) 378-9571

Resource Recovery, Inc.

Edina, MN

(612) 828-9722 (service)

(701) 234-9102 (sales)

Superior Lamp Recycling, Inc.

Mineral Springs Facility

1275 Mineral Springs Drive

Port Washington, WI 53074

(800) 556-LAMP (5267)

USA Lamp and Ballast Recyclers

Call John Fortino at 1-800-778-6645

for information on disposal facilities.

USA Lights

2007 County Road, C-2

Roseville, MN 55113

(612) 628-9370

\section{Ballast Recycling Services}

Alta Resource Management Services, Inc.

88-B Industry Avenue

Spingfield, MA 01104-9926

(800) 730-ALTA or (413) 734-3399

Dynex Environmental, Inc.

6801 Industrial Loop

Milwaukee, WI 53129

(800) $249-3310$ or (414) 421-4959

4751 Mustang Circle

St. Paul, MN 55112

(800) $733-9639$ or (612) $784-4040$

Eastern Environmental Technologies

Portchester, NY

(914) $934-2100$

Ensquare, Inc.

Newton Upper Falls, MA

(617) $776-7320$ 
FulCircle Ballast Recyclers

168 Brattle Street

Cambridge, MA

(800) 775-1516

Baltimore, MD

(717) 932-1022

- New York, NY

(800) 581-0857

San Francisco, CA

(916) 649-9194

Los Angeles, CA

(800) $775-1516$

Atlanta, GA

(800) $775-1516$.

Chicago, IL

(708) 434-0593

Detroit, MI

(313) 651-6589

Global Recycling Technologies, Inc. PO Box 651

Randolph, MA 02368

(617) $341-6080$

Lighting Resources, Inc.

Pomona, CA

(714) 622-0881

Light Cycle, inc 1222 University Avenue

St. Paul, MN 55104

(612) 641-1309

Luminaire Recyclers Inc.

2161 University Avenue, Suite 206

St. Paul, MN 55114

(612) 649-0079

Recycle Technologies, Inc.

1480 N. Springdale Road

Waukesha, WI 53186

(800) 305-3040

(414) $798-3040$
S.D. Myers

180 South Avenue

Tallmadge, Ohio 44278

(216) 633-2666

Salesco U.S.A.

Boston, MA

(617) 344-4074

Chicago, IL

(708) 803-0880

Dallas, TX

(214) $661-8819$

Honolulu, $\mathrm{HI}$

(800) 368-9095

Phoenix, AZ

(800) 368-9095

San Diego, CA

(619) 793-3460

Transformer Service, inc.

Concord, $\mathrm{NH} 03302$

(603) 224-4006

Transtec Environmental

Niagara Falls, NY

(716) 283-6174

USA Lamp and Ballast Recyclers

Call John Fortino at 1-800-778-6645

for information on disposal facilities.

United States Ballast

Wausau, WI

(800) $715-5267$

THIS IS NOT A COMPLETE LIST OF COMPANIES WHO PROVIDE RECYCLING AND DISPOSAL SERVICES THROUGHOUT THE UNITED STATES. COMPANIES LISTED IN THIS SECTION ARE NOT ENDORSED BY THE EPA OR THE GREEN LIGHTS PROGRAM. EPA DOES NOT SCREEN LISTED COMPANIES AND CANNOT CONFIRM THE METHODS THESE COMPANIES MAY USE IN THEIR RECYCLING PROCESS. 


\section{GREEN LIGHTS}

\section{A Bright Investment in the Environment}

Green Lights is an exciting and innovative program sponsored by the US Environmental Protection Agency (EPA) that encourages major US corporations and other organizations to install energy-efficient lighting technologies.

Organizations that make the commitment to Green Lights will profit by lowering their electricity bills, improving lighting quality, and increasing worker productivity. They will also reduce the air pollution caused by electricity generation.

For more information contact the Green Lights program office.

Green Lights Program

US EPA

$401 \mathrm{M}$ Street, SW (6202J)

Washington, DC 20460
Lightirg Waste Disposal is one of a series of documients known collectively as the Lighting Upgrade Manual. Other documents in the Manual are listed below.

\section{Lighting Upgrade Manual}

\section{PLANNING}

- Green Lights Program

- Implementation Planning Guidebook

- Financial Considerations

- Lighting Waste Disposal

- Progress Reporting

- Communicating Green Lights Success

\section{TECHNICAL}

- Lighting Fundamentals

- Lighting Upgrade Technologies

- Lighting Maintenance

- Lighting Evaluations

- The Lighting Survey

\section{Green Lights Information Hotline}

$\begin{array}{ll}\pi & (202) 775-6650 \\ \text { Fax: } & (202) 775-6680\end{array}$

To order other documents or appendices in this series, contact the Green Lights Hotline at (202) 775-6650. Look in the monthly Green Lights Update newsletter for announcements of new publications.

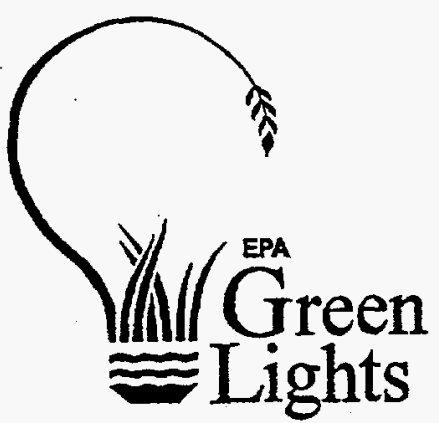

